INTERNATIONAL MONETARY FUND

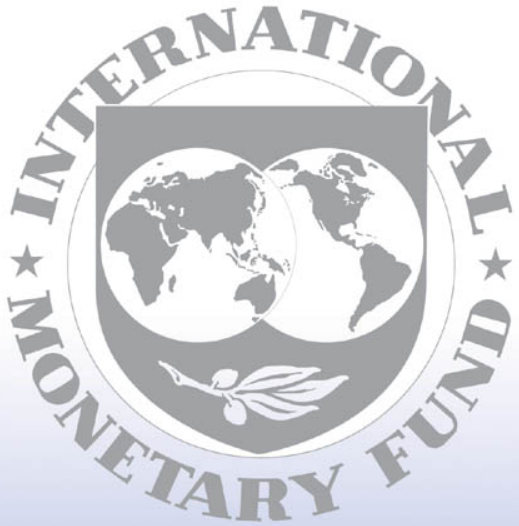

Staff

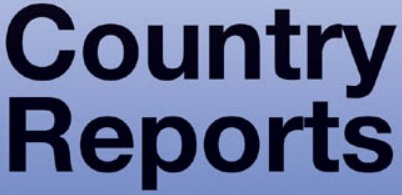




\section{Bulgaria: Second Review Under the Stand-By Arrangement and Requests for Waiver of Performance Criteria and Postponement of Third Review-Staff Report; Staff Statement; Press Release on the Executive Board Discussion; and Statement by the Executive Director for Bulgaria}

In the context of the second review under the Stand-By Arrangement and requests for a waiver of performance criteria and postponement of the third review, the following documents have been released and are included in this package:

- $\quad$ the staff report for the Second Review Under the Stand-By Arrangement and Requests for Waiver of Performance Criteria and Postponement of Third Review, prepared by a staff team of the IMF, following discussions that ended on January 26, 2006, with the officials of Bulgaria on economic developments and policies. Based on information available at the time of these discussions, the staff report was completed on March 15, 2006. The views expressed in the staff report are those of the staff team and do not necessarily reflect the views of the Executive Board of the IMF.

- $\quad$ a staff statement of March 28, 2006 updating information on recent developments.

- $\quad$ a Press Release summarizing the views of the Executive Board as expressed during its April 3, 2006 discussion of the staff report that completed the review and requests.

- $\quad$ a statement by the Executive Director for Bulgaria.

The documents listed below have been or will be separately released.

Letter of Intent sent to the IMF by the authorities of Bulgaria*

Second Supplementary Memorandum of Economic and Financial Policies by the authorities Bulgaria*

*Also included in Staff Report

The policy of publication of staff reports and other documents allows for the deletion of market-sensitive information.

To assist the IMF in evaluating the publication policy, reader comments are invited and may be sent by e-mail to publicationpolicy@imf.org.

Copies of this report are available to the public from

International Monetary Fund • Publication Services

$70019^{\text {th }}$ Street, N.W. • Washington, D.C. 20431

Telephone: (202) 623-7430 • Telefax: (202) 623-7201

E-mail: publications@imf.org • Internet: http://www.imf.org

Price: $\$ 15.00$ a copy

International Monetary Fund

Washington, D.C. 
This page intentionally left blank

CInternational Monetary Fund. Not for Redistribution 
INTERNATIONAL MONETARY FUND

\title{
BULGARIA
}

\section{Second Review Under the Stand-By Arrangement and Requests for Waiver of Performance Criteria and for Postponement of Third Review}

\author{
Prepared by the European Department \\ (In consultation with the Policy Development and Review Department) \\ Approved by Ajai Chopra and Matthew Fisher
}

March 15, 2006

Contents

List of Acronyms $\underline{4}$

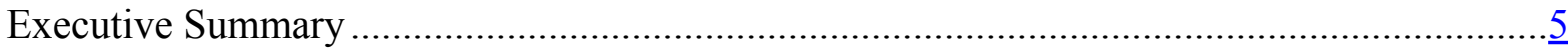

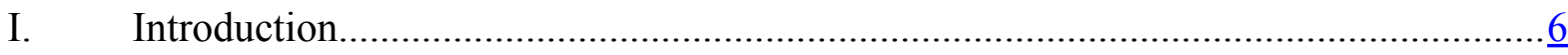

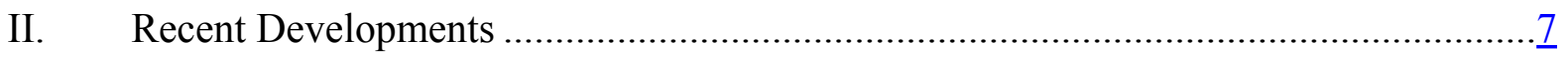

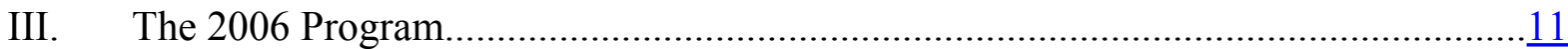

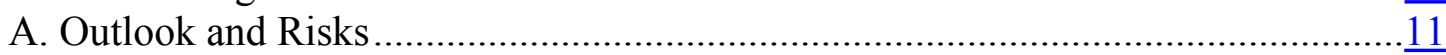

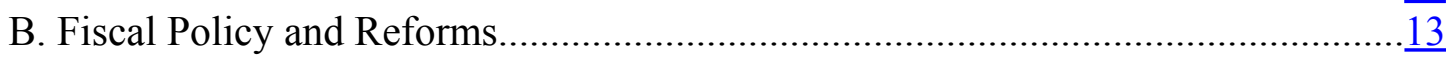

C. Incomes and Labor Market Policies...............................................................14

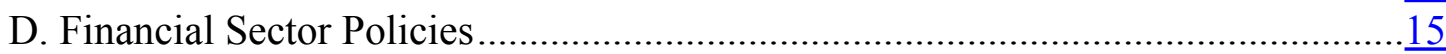

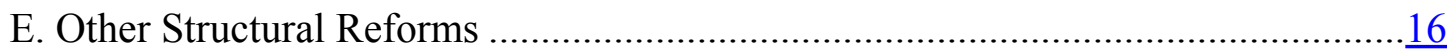

F. Program Conditionality and Waiver Requests .................................................16

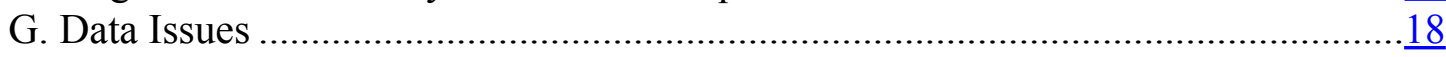

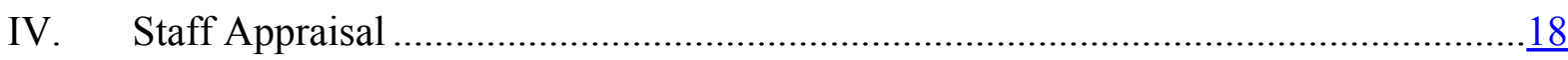

Text Tables

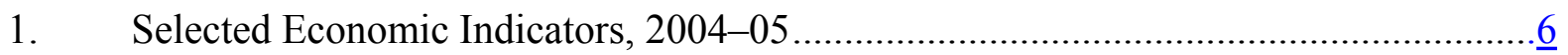

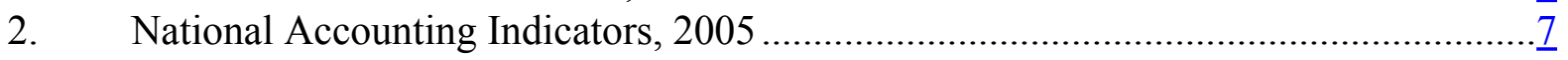

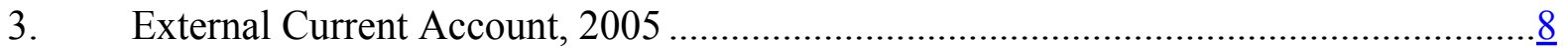

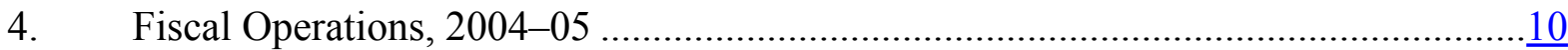

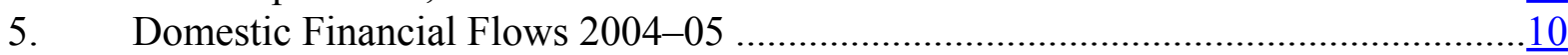

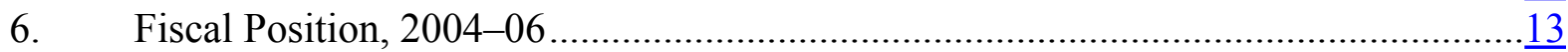

7. Structural Conditionality Under the Stand-By Arrangement, $2006 \ldots \ldots \ldots \ldots \ldots \ldots \ldots \ldots \ldots \ldots . .17$ 


\section{Text Figures}

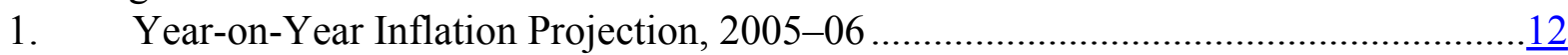

2. Current Account Deficit and Trade Volume Growth, 2005-06 ……………….........12

3. Household Credit and Imports of Consumer Goods, 2002-05 ...................................

Box

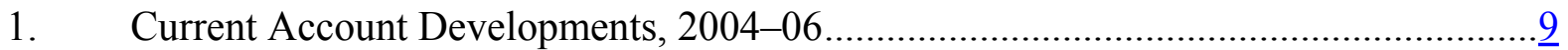

Figures

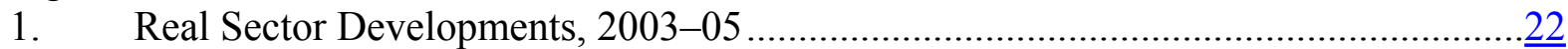

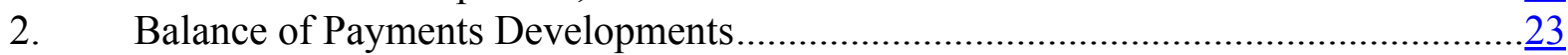

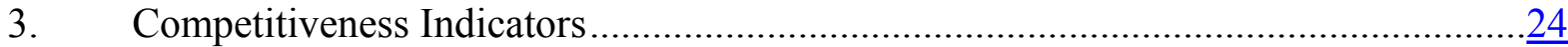

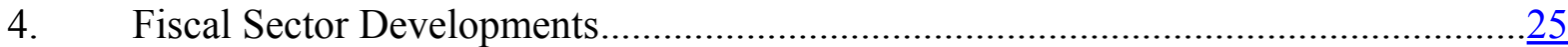

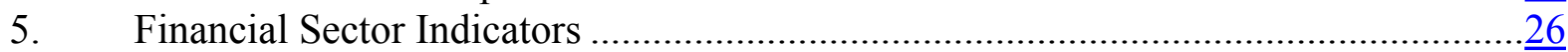

6. Bulgaria and Comparator Countries, Selected Macroeconomic Indicators, 2004-05.27

7. Baseline Medium-Term Projections, 2001-2011 …………………………….......28

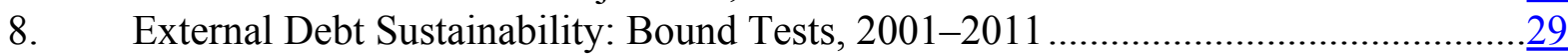

9. Public Sector Debt Sustainability: Bound Tests, 2001-2011 …………………..........

Tables

1. $\quad$ Proposed New Schedule of Purchases Under the Stand-By Arrangement ....................31

2. Observance of Structural Conditionality Under the Stand-By Arrangement in $2005 . \underline{32}$

3. Quantitative Performance Criteria and Indicative Targets Under the Stand-By

Arrangement (In millions of leva)

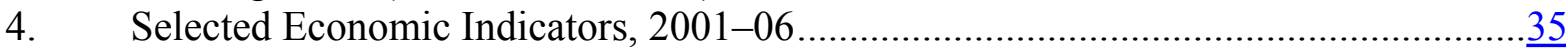

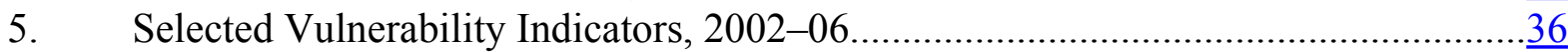

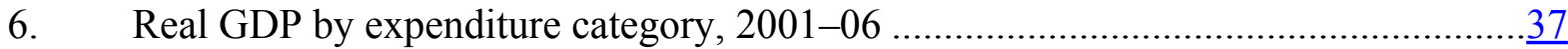

7. Balance of Payments, 2004-06 (In millions of euros) ...............................................38

8. Balance of Payments, 2004-06: Analysis of Developments .....................................

9. Monetary Survey, 2004-06 (In millions of leva) ……………................................40

10. General Government Operations, 2001-06 (In millions of leva) ...............................41

11. General Government Operations, 2001-06 (In percent of GDP) …..........................

12. Balance of Payments, 2002-2011 (In millions of euros).........................................43

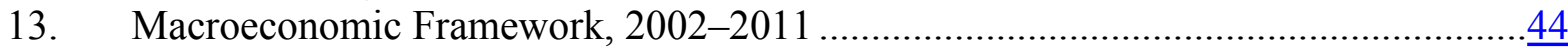

14. External Debt Sustainability Framework, 2001-2011 (In percent of GDP)..................45

15. Public Sector Debt Sustainability Framework, 2001-2011 (In percent of GDP).........46

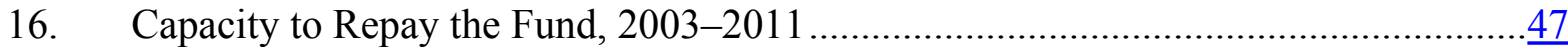

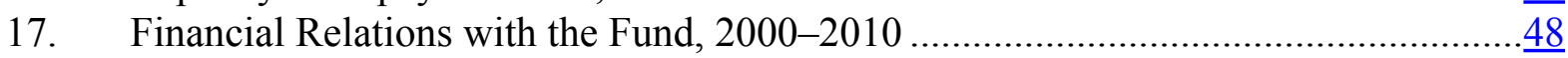

Appendices

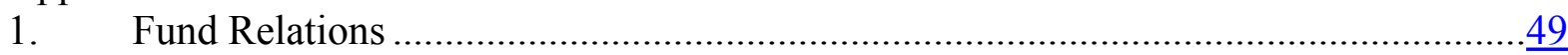

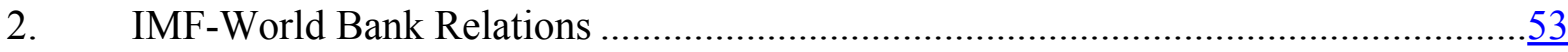

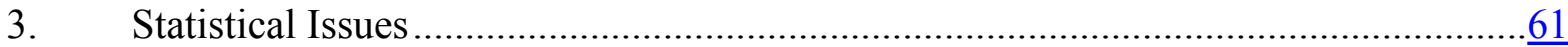


Appendix Tables

18. ROSCs.

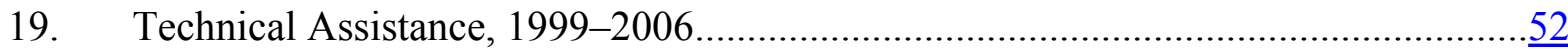

20. Active World Bank Operations (Net of cancellations) ……………………….........60

21. Common Indicators Required for Surveillance ……………....................................

Attachment

I. Letter of Intent and Second Supplementary Memorandum of Economic and Financial Policies

\section{Main Websites for Bulgarian Data}

Data in this report reflect statistical information received by March 1, 2006.

More recent data can be obtained from the following internet sources:

National Statistical Institute .http://www.nsi.bg Bulgarian National Bank. http://www.bnb.bg Ministry of Finance. http://www.minfin.bg

Information on Bulgarian economic statistics can be found at the Fund's Special Data Dissemination Standard website:

http://dsbb.imf.org/Applications/web/sddscountrycategorylist/?strcode=BGR 


\section{LIST OF ACRONYMS}

\begin{tabular}{|c|c|}
\hline $\mathrm{BNB}$ & Bulgarian National Bank \\
\hline CAS & Country assistance strategy \\
\hline $\mathrm{CBA}$ & Currency board arrangement \\
\hline CIT & Corporate income tax \\
\hline CPI & Consumer price index \\
\hline $\mathrm{EC}$ & European Commission \\
\hline EPA & Ex-Post Assessment \\
\hline EU & European Union \\
\hline EUR & European Department \\
\hline FDI & Foreign direct investment \\
\hline FESAL & Finance and Enterprise Adjustment Loan \\
\hline FSAP & Financial sector assessment program \\
\hline FSC & Financial Supervision Commission \\
\hline GNFS & Goods and nonfactor services \\
\hline LOI & Letter of intent \\
\hline MFD & Monetary and Financial Systems Department \\
\hline MOF & Ministry of Finance \\
\hline NEER & Nominal effective exchange rate \\
\hline NFA & Net foreign assets \\
\hline NHIF & National Health Insurance Fund \\
\hline NRA & National Revenue Agency \\
\hline NSI & National Statistics Institute \\
\hline OED & Office of Executive Directors \\
\hline PDR & Policy Development and Review Department \\
\hline PEIR & Public expenditure and institutional review \\
\hline PIT & Personal income tax \\
\hline REER & Real effective exchange rate \\
\hline ROSC & Report on the observance of standards and codes \\
\hline SDDS & Special data dissemination standard \\
\hline SMEFP & Supplementary memorandum of economic and financial policies \\
\hline SSMEFP & Second supplementary memorandum of economic and financial policies \\
\hline $\mathrm{SOE}$ & State-owed enterprise \\
\hline VAT & Value-added tax \\
\hline WTO & World Trade Organization \\
\hline
\end{tabular}




\section{EXECUTIVE SUMMARY}

- Despite policy tightening, the external current account deficit has widened sharply since the first $S B A$ review, heightening external vulnerability. The current account deficit widened to nearly 15 percent of GDP as private saving declined and investment rose, and the external debt ratio increased as the current account gap was partly financed by private external borrowing. By contrast, in line with program commitments, the fiscal position has strengthened further and credit expansion slowed.

- In view of the larger than expected widening of the current account deficit, the economic program for 2006 relies on fiscal and credit restraint to rein in demand and strengthen the balance sheets of government and banks, and on structural reforms to stimulate supply.

The fiscal target is a surplus of 3 percent of GDP, up from 2.3 percent in 2005. The revenue projection assumes a neutral impact of tax administration reforms. Half of any excess revenue is to be saved under an adjustor. The surplus target hinges on the full implementation of agreed discretionary cuts and resisting pressure for additional spending.

The credit program envisages reducing credit expansion to 17.5 percent, down from 32.3 percent in 2005 . Quarterly credit growth limits and higher penalties for exceeding them are expected to help ensure achievement of this target. Measures to slow down household credit should additionally contribute to current account adjustment and crowd in business credit.

Structural reforms aim at improving the business climate. They include introduction of a new business register, steps to improve the functioning of the labor market, and privatization or concessioning of state assets. 


\section{INTRODUCTION}

1. A staff team ${ }^{1}$ visited Sofia during October 13-26, 2005 and January 19-26, 2006 to conduct discussions on the second review under the stand-by arrangement. The 25month arrangement in the amount of SDR 100 million (15.62 percent of quota) was approved on August 6, 2004 and its first review was completed on May 18, 2005 (IMF Country Reports No. 2004/267 and 2005/169). The authorities continue to treat the arrangement as precautionary. They made early repayments to the Fund in December 2005 and February 2006 and intend to make all remaining repurchases on the expectations schedule (Table 1). The second review has been delayed because of the election and the time required to reach agreement with the new government on the fiscal parameters of the program.

\section{EU accession with an unchanged peg of the lev to the euro under the currency} board arrangement (CBA) remains the authorities' overarching objective. Following parliamentary elections in June 2005, the socialist party, the party of ex-king Simeon, and the Turkish minority party formed a new government in August. As the government is seeking to accede to the EU on January 1, 2007, required legislation —including judicial reform - is likely to be adopted under fast-track procedures before the EC publishes its recommendation in mid-May 2006. Macroeconomic policy is aimed at observing all Maastricht criteria in time for euro adoption in 2009-10.

\section{Macroeconomic policy implementation was broadly in line with commitments} and economic growth was strong, but the external current account deficit widened sharply, heightening external vulnerability (Text Table 1). The current account deterioration to nearly 15 percent of GDP, relative to $71 / 2$ percent of GDP projected at the time of the first review, resulted from an unanticipated increase in domestic demand pressures which were aggravated by supply shocks ( $₫ 5$ and 6). Because of the

Text Table 1. Bulgaria: Selected Economic Indicators, 2004-05 (percent of GDP unless otherwise indicated)

\begin{tabular}{lrrr}
\hline & 2004 & \multicolumn{2}{c}{2005} \\
\cline { 3 - 4 } & & First Rev. & Est. \\
\hline Real GDP growth (percent) & 5.6 & 5.5 & 5.6 \\
Consumer price index (percent, ave.) & 6.1 & 4.0 & 5.0 \\
$\quad$ (percent, end of period) & 4.0 & 3.5 & 6.5 \\
Current account balance & -8.5 & -7.6 & -14.9 \\
External debt & 64.4 & 57.5 & 67.4 \\
Fiscal balance & 1.8 & 1.0 & 2.3 \\
Broad money growth (percent) & 21.4 & 19.8 & 27.7 \\
Credit growth (percent) & 48.6 & 30.0 & 32.3 \\
\hline Sources: Bulgarian authorities. & & &
\end{tabular}

${ }^{1}$ Messrs. Flickenschild (head), Duenwald, Herderschee, Luengnaruemitchai (all EUR), Mukhopadhyay (PDR), and Roaf (resident representative). The missions met with the Prime Minister, all key economic ministers, the Governor of the Bulgarian National Bank (BNB), and representatives of parliament, trade unions, and the private sector, and coordinated its work closely with World Bank staff. Mr. Yotzov (OED) participated in some meetings. 
large external slippage, the review discussions focused on ways to reduce the external vulnerabilities and on meeting the broader objectives of the original program.

4. All quantitative performance criteria for end-June and end-September 2005 and indicative targets for end-December 2005 were observed but the pace of structural reforms was slower than envisaged under the program (Table 2). Two structural performance criteria - the adoption of the National Revenue Agency (NRA) procedural code and the incorporation of the judicial accounts in the budgetary payments system - were implemented with delays. A third performance criterion was only partially implemented: winning bids were selected for two out of three electricity generation companies, but the highest offer for the third one was rejected as unsatisfactory. The authorities request waivers for the nonobservance of these performance criteria (LOI, \2). Two structural benchmarks that did not require legislative action were observed on time. However, benchmarks that required governmental or parliamentary action were missed and in some instances implemented with delay.

\section{RECENT DEVELOPMENTS}

5. The 2005 current account deficit is estimated to have been nearly 15 percent of GDP, or nearly double the first-review projection, mainly due to booming domestic

demand. Domestic demand expanded almost twice as fast as projected, but GDP growth was in line with projections as this expansion was offset by lower net exports (Table 6). The domestic demand expansion explains most of the current account deterioration, the remainder being due to higher net income payments and lower transfers. The rapid growth in domestic demand led to a sharp fall in private saving that was only partially offset by an increase in
Text Table 2 Bulgaria: National Accounting Indicators, 2005

\begin{tabular}{|c|c|c|c|}
\hline & First Rev. & Estimate & Diff. \\
\hline \multirow[t]{2}{*}{ GDP (Lev billion) } & 41.3 & 41.6 & 0.3 \\
\hline & \multicolumn{3}{|c|}{ (percent of GDP) } \\
\hline Consumption & 85.5 & 88.9 & 3.3 \\
\hline Government & 18.3 & 19.2 & 0.9 \\
\hline Non-government & 67.3 & 69.7 & 2.4 \\
\hline Gross domestic savings & 14.5 & 11.2 & -3.3 \\
\hline Government & 6.7 & 8.3 & 1.6 \\
\hline Non-government & 7.8 & 2.9 & -4.9 \\
\hline Gross domestic investment & 25.0 & 27.9 & 3.0 \\
\hline Government & 4.5 & 4.8 & 0.3 \\
\hline Non-government & 20.5 & 23.1 & 2.7 \\
\hline Of which: greenfield FDI 1/ & 5.4 & 7.8 & 2.4 \\
\hline Domestic S/I balance & -10.4 & -16.7 & -6.3 \\
\hline Government & 2.2 & 3.5 & 1.3 \\
\hline Non-government & -12.7 & -20.2 & -7.5 \\
\hline Factor services and transfers, net & 2.8 & 1.8 & -1.0 \\
\hline Current account balance & -7.6 & -14.9 & -7.3 \\
\hline
\end{tabular}

public saving (Text Table 2). With banks aggressively providing household credit, private consumption surged, possibly reflecting rising expectations of real income convergence in the context of approaching EU membership. Higher investment was driven by greenfield foreign investment, but gross private foreign debt was 10 percentage points of GDP above projection. Available national accounts data, however, do not permit a precise breakdown of the relative contribution of households and corporations to the deterioration of the saving- 
investment balance. In the second half of the year, domestic demand pressures also pushed up core inflation (Figure 1).

\section{The slowdown in export volume growth appears to be primarily due to} temporary factors rather than competitiveness problems (Box 1). Export volume growth slowed as a result of the summer floods, the lifting of EU quotas on textile imports ${ }^{2}$, and restructuring in the metals sector (Table 8 and Text Table 3). Competitiveness indicators (such as relative unit labor costs and export market shares) though are satisfactory (Figure 3), and Bulgaria remained an attractive destination for foreign investment. ${ }^{3}$ However, the buoyancy of trade prices is expected to have an adverse effect on the trade balance for some time. Apart from the widening of the negative net

Text Table 3. Bulgaria: External Current Account, 2005

\begin{tabular}{|c|c|c|c|}
\hline & First review & Estimate & Diff. \\
\hline Current Account & -7.6 & -14.9 & -7.3 \\
\hline Trade balance & -14.9 & -19.2 & -4.3 \\
\hline Exports & 43.8 & 44.5 & 0.7 \\
\hline Volumes & $\ldots$ & $\ldots$ & -3.3 \\
\hline Prices & $\ldots$ & $\ldots$ & 4.0 \\
\hline Imports & -58.7 & -63.7 & -5.0 \\
\hline Volumes & $\ldots$ & $\ldots$ & 0.3 \\
\hline Prices & $\ldots$ & $\ldots$ & -5.3 \\
\hline Services & 4.4 & 2.5 & -1.9 \\
\hline Travel (receipts) & 9.5 & 8.9 & -0.6 \\
\hline Other services, net & 0.5 & -0.7 & -1.2 \\
\hline Income, net & -1.9 & -2.6 & -0.7 \\
\hline Transfers, net & 4.8 & 4.4 & -0.4 \\
\hline
\end{tabular}

Sources: Bulgarian authorities; and Fund staff estimates. income balance, which resulted from higher profits of foreign-owned enterprises, the reasons for the deterioration of the invisibles accounts are less clear: tourism was less buoyant than expected, possibly due to the floods; the sharp deterioration of other services may have been related to the surge in investment; and the lower than expected private transfer receipts could reflect a switch to other channels of payment. ${ }^{4}$

${ }^{2}$ Quotas were subsequently reimposed on imports from China.

${ }^{3}$ The NSI is in the process of revising employment and output data, which may result in changes in the ULC-based REER and the assessment of competitiveness.

${ }^{4}$ Positive net unidentified inflows amounted to almost 5 percent of GDP in 2005 and are being reviewed by the BNB. Forthcoming methodological changes to transportation and migrant labor revenue are likely to reduce the current account deficit by some 3 percent of GDP. Moreover, FDI data do not reflect fully the scale of real estate sales to foreigners. 


\section{Box 1. Current Account Developments, 2004-06}

The current account deficit widened to nearly 15 percent of GDP in 2005 , up sharply from $81 \frac{2}{2}$ percent in 2004. The bulk of the deterioration occurred in the trade account, but the services balance also weakened.

The trade balance was affected by exogenous shocks and high domestic demand. The program's demand management policies, the partial unwinding of the shocks, and substantial export-oriented investment previously undertaken should aid a recovery in 2006. The buoyancy of both export and import prices is exacerbating the effect on the balance, because of the larger share of imports.

- Real export growth in $\mathbf{2 0 0 5}$ was depressed by several temporary factors. The summer floods damaged crops and infrastructure, affecting exports of agricultural raw materials and processed goods. The major steel producer in the country, currently engaged in a substantial expansion of capacity, shut down part of its plant, and the impact of the expiration of the Multi-Fiber Agreement was larger than anticipated.

Together, these factors affected nearly 35 percent of merchandise exports. However, in other areas - especially manufactured investment goods, but also consumer goods excluding textilesexport growth was robust. This, together with indicators such as a decline in relative unit labor costs and rising export market shares, suggests that lack of competitiveness is

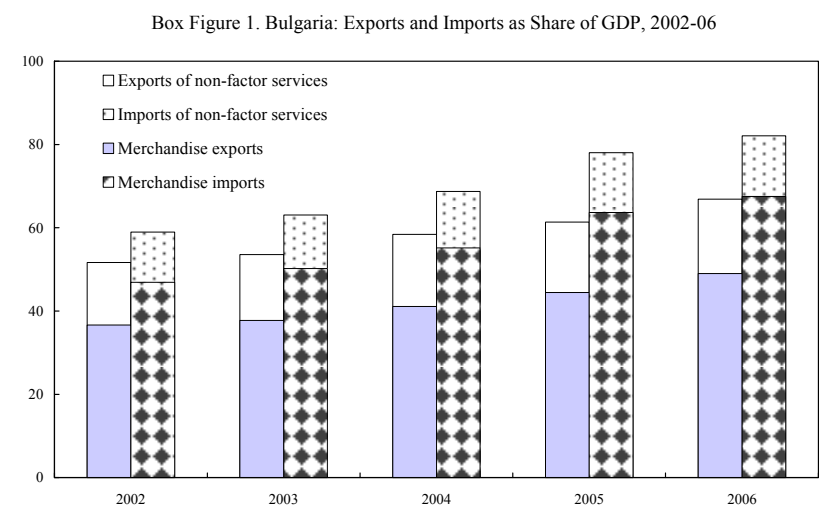
not the root cause of the slowdown in export growth (Figure 3). Accordingly, reimposition of quotas on Chinese textile exports to the EU in the second half of 2005, substantial additions to capacity at the steel plant, high recent investment more broadly, and the recovery from the floods should help export growth return to its previous trend in 2006.

- Real import growth remained high in $\mathbf{2 0 0 5}$, notwithstanding a sharp increase in import prices. However, the composition of imports shifted markedly to investment goods, while the growth rate of consumption imports moderated. In 2006, the programmed tightening of policies should further ease consumption demand, but the demand for investment imports is expected to remain high.

- Higher export and import prices, which both increased by nearly 14 percent in 2005 , also contributed to the deterioration of the trade balance. The price increase, which is in excess of the rise in the GDP deflator, resulted in both exports and imports rising as a share of GDP, with the impact on the trade balance being greater for imports because of their larger relative size (Box Figure 1). In 2006, continued high growth of prices will again drive the increase of both exports and imports relative to GDP, with the trade deficit projected to decline in relation to GDP because of the pick-up in export volume growth.

The deterioration in the services balance is harder to explain. Some of the deterioration resulted from higher transportation costs, and the growth of tourism exports may have been affected by the floods. The marked deterioration in the "Other services" balance, however, is not well understood. The spike in the imports of such services could reflect the services part of large investment projects, while the export developments may, in part, reflect a natural slowdown following very rapid growth in 2004 . Anecdotal evidence does not, however, suggest competitiveness problems. Indeed, there appears to be substantial interest by foreign investors, including by multinationals, in business process outsourcing. 
7. Large current account deficits are not unusual in the region, but the magnitude and the speed of the slippage in Bulgaria were a surprise (Figure 6). A number of EU accession countries have experienced large investment inflows because of capital scarcity high risk-adjusted rates of return. These capital inflows have contributed to growth and convergence. Compared to Bulgaria, however, the Baltic countries have experienced higher growth and a slower deterioration in their net international investment position.

\section{In response to the rising external vulnerabilities, and as envisaged in the}

\section{program, a cautious stance on}

fiscal policy was pursued (Text Table 4). Rapidly rising indirect taxes (especially VAT) boosted revenue above projections. This overperformance was largely saved in accordance with the program. ${ }^{5}$ Expenditure was

0.8 percentage point of GDP above projection as a result of unbudgeted spending on flood relief and the partial clearance of hospital arrears. With other expenditure also running ahead of budgeted amounts, the new government curtailed customary year-end spending; pension bonuses were about half their 2004 level, and no funds were released for bonuses for government workers.

\section{Policies to restrain bank} lending were continued, but nonbank financial intermediation grew rapidly (Text Table 5 and $\uparrow 13$ ). As the bank credit flow exceeded 12 percent of GDP in 2004, the BNB set quantitative limits on bank lending to address the emerging macroeconomic imbalances and prudential risks. These measures were broadly observed, although end-year window dressing led to a 0.6 percent of GDP lending spike (reversed in early 2006) that pushed the credit flow to
Text Table 4. Bulgaria: Fiscal Operations, 2004-05 (percent of GDP, unless otherwise indicated)

\begin{tabular}{lrrrr}
\hline & 2004 & \multicolumn{2}{c}{2005} & \\
\cline { 3 - 5 } & Actual & First rev. & Act. & Diff. \\
& & & & \\
\hline Total revenue and grants & 39.3 & 38.8 & 41.0 & 2.2 \\
Total expenditure & 37.5 & 37.8 & 38.6 & 0.8 \\
Primary balance & 3.6 & 2.7 & 4.0 & 1.3 \\
Overall balance & 1.8 & 1.0 & 2.3 & 1.3 \\
Memo items: & & & & \\
Flood relief spending & $\ldots$ & 0.0 & 0.6 & 0.6 \\
Hospital arrears clearance & $\ldots$ & 0.0 & 0.2 & 0.2 \\
GDP (billions of leva) & 38.0 & 41.3 & 41.6 & 0.3 \\
\hline Sources: Bulgarian Ministry of Finance; and Fund staff estimates. &
\end{tabular}

Sources: Bulgarian Ministry of Finance; and Fund staff estimates. 
11 percent of GDP, 0.8 percentage points more than projected. Household credit rose as a share of total bank lending, and firms increasingly financed themselves through bonds and leasing. On the whole, financial flows to the private sector were little changed year on year. Despite the surge in lending, the banking sector (including the balance sheets of all major banks) appears sound, with overdue loans well provisioned and a high capital adequacy ratio. ${ }^{6}$ The constraints on bank lending contributed to development of the small but rapidly growing nonbank financial sector.

10. After languishing in $\mathbf{2 0 0 5}$, structural reforms have picked up in recent months. Structural reforms had slowed before and after the election, but in December 2005 the NRA procedural code was approved by parliament and on January 1, 2006 the long-planned NRA was launched. Health care reform accelerated as political pressure built up in the wake of hospital arrears accumulation. An EU-consistent insurance law was adopted in December, modernizing the supervisory regime. However, there was only limited progress with privatization and labor market reforms. Key privatization transactions were challenged in the courts. The new government required time for consultations with the social partners regarding its labor market policies.

\section{The 2006 Program}

\section{Discussions focused on measures to contain rising external vulnerabilities and} on policies to boost growth. The authorities agreed that the widening current account deficit and rising foreign debt had increased Bulgaria's vulnerability to exogenous shocks. To address the saving-investment imbalance, policies were needed to reduce consumption growth and improve the trade balance by boosting competitiveness, while providing room for investment. Staff and authorities concurred that financial sector vulnerability-while rising after three years of rapid credit growth - remains contained, but measures were nonetheless agreed to strengthen bank balance sheets and nonbank supervision. To reduce excess demand, the demand management measures are complemented by supply enhancing structural reforms.

\section{A. Outlook and Risks}

12. The policies outlined in the SSMEFP are designed to sustain economic growth while bringing the current account deficit and inflation under control. Baseline

\footnotetext{
${ }^{6}$ Loans overdue by more than 30 days are 7.7 percent of total loans, with a declining share of overdue business loans more than offset by arrears on household loans during 2005. Provisions exceed 50 percent of overdue loans. Risk-weighted capital adequacy is 15.2 percent (Table 5).
} 
projections assume EU accession in 2007 and respect the 40 percent expenditure-to-GDP limit under the coalition agreement (\$7).

- Real GDP growth is projected to remain at $5 \frac{1}{2}$ percent in 2006 , while the current account deficit should narrow from 14.9 to 12.9 percent of GDP. In response to tighter macroeconomic policies, domestic demand growth is projected to slow. In contrast to 2005 , net exports are expected to make a small positive contribution to growth. Reflecting the rapidly expanding capital stock and the expected impact of structural reforms on total factor productivity growth, GDP growth is projected to exceed 6 percent over the medium term.

- Inflation is projected to peak in Q1 before abating to 5.7 percent by year end. On top of the price increases in late 2005, the authorities brought forward EU-required increases in excise taxes on alcoholic beverages and tobacco products to January 2006, raising the projection of average inflation by 2.3 percentage points. Later in the year, food prices are projected to decline as the impact of last year's floods dissipates (Text Figure 1). Inflation is targeted to decline

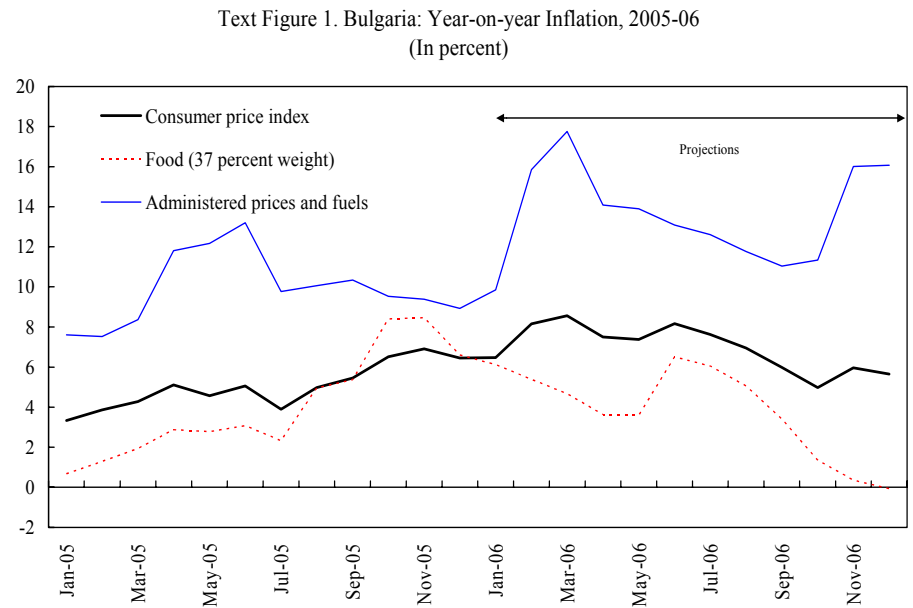
to 2.5 percent in 2008 , consistent with the government's goal of euro adoption in 2009-10.

- Private domestic saving is projected to recover to 4.6 percent of GDP in 2006, an improvement of 2 percentage points. Private consumption growth is projected to slow to slightly more than half its 2005 rate in response to the large price increases in late 2005 and early 2006, tight incomes policies, and a slowdown in household credit in the wake of recent measures. Over the medium term, saving is projected to continue to increase faster than investment on the strength of a continued slowdown in private consumption growth as actual income approaches expected permanent income (Figure 7).

- The external outlook hinges significantly on rapid export growth (Text Figure 2; see also Box 1). Export volume growth is projected to revert to trend following the expansion of industrial capacity, a recovery of

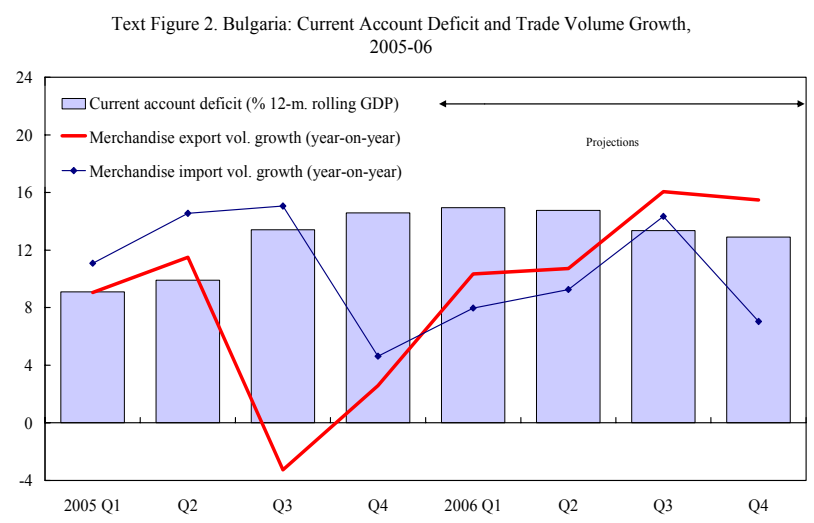

CInternational Monetary Fund. Not for Redistribution 
agricultural production, and higher EU growth. Competitiveness will be further improved by continued wage restraint and the recent and prospective reductions in nonwage labor costs. Import growth is projected to moderate but will likely remain high due to rising imports of investment goods and raw materials for export processing (Table 7 and Figure 2). At 9.4 percent of GDP, FDI inflows are projected to finance over 70 percent of the current account deficit. Half of the projected increase in foreign reserves has been pledged as a security deposit for future imports of military hardware, reducing the reserve cover ratios (Table 7 and $\$ 15$ ). The current account deficit is projected to narrow to 7 percent of GDP in 2011, when foreign debt is expected to fall below 60 percent of GDP (Table 12). Projected debt ratios are sensitive to noninterest current account shocks but less so to interest rate or GDP shocks (Figure 8).

\section{While the program is designed to contain Bulgaria's vulnerabilities, risks}

remain. The measures in the proposed program aim to arrest the recent current account deterioration and gradually reduce the current account deficit, while some of the one-off factors that contributed to the deterioration should unwind automatically. However, the current account deficit may remain uncomfortably high over the next few years as Bulgaria remains an attractive destination for foreign investment and if domestic savings stay low. The program for 2006 will strengthen the position of reform and stability minded policymakers and avoid significantly weaker fiscal, credit, and structural policies - a point persuasively made in the 2004 EPA paper (IMF Country Report No. 04/176).

\section{B. Fiscal Policy and Reforms}

14. The 2006 fiscal program aims for a surplus of $\mathbf{3}$ percent of GDP, compared with a surplus of 0.5 percent envisaged at the first review and a balanced budget approved by parliament (Text Table 6). ${ }^{7}$ Although the fiscal position is solid, a modest further tightening relative to 2005 was deemed necessary in view of the recent sharp deterioration of the private saving-investment balance to buttress investor confidence that the authorities remain committed to sound policies and medium-term sustainability in the context of the CBA.

Text Table 6. Bulgaria: Fiscal Position, 2004-06 (Percent of GDP)

\begin{tabular}{lrrrrrr}
\hline & 2004 & \multicolumn{3}{c}{2005} & & \multicolumn{2}{c}{2006 proj. } \\
\cline { 2 - 4 } & & First review & Actual & & First review & Second review \\
\hline Revenue & 39.3 & 38.8 & 41.0 & 38.2 & 39.9 \\
Expenditure & 37.5 & 37.8 & 38.6 & 37.6 & 36.9 \\
Balance & 1.8 & 1.0 & 2.3 & 0.5 & 3.0 \\
\hline
\end{tabular}

Sources: Bulgarian authorities; and Fund staff estimates.

${ }^{7}$ In keeping with a long-standing but nontransparent practice, the authorities had submitted a budget with conservative revenue projections out of concern that a proposed budget surplus would have led parliament to cut taxes and raise expenditure. 
- Revenue is projected at 39.9 percent of GDP, or $2 \frac{1}{4}$ percentage points higher than in the approved budget. Relative to the 2005 outcome, the revenue-to-GDP ratio will decline by 1 percentage point, principally reflecting a drop of 1.4 percentage points due to a 6 percentage point reduction in social security contributions but also the effect of income and profit tax reductions ( $(\mathbf{6})$. These revenue losses will be mitigated by higher excise and property taxes, some broadening of indirect tax bases, and improving compliance. Nontax revenue is projected to decline in relation to GDP following a rise in 2005 due to one-off factors. Under an adjustor the authorities will save 50 percent of any revenue overperformance $(\boldsymbol{\Phi} 4)$.

- Expenditure is projected to decline to 36.9 percent of GDP. However, real expenditure is still projected to increase by 0.9 percent, following a jump of 8.8 percent in 2005. Expenditure plans aim to limit discretionary spending to 93 percent of the budgeted amounts, providing savings of $3 / 4$ percent of GDP. The release of the remaining 7 percent is conditional upon a significant reduction of the current account deficit ( $(\mathbf{} 4)$.

\section{The fiscal program is subject to significant risks, and the authorities are} committed to take compensatory measures if these materialize. The implementation of major tax administration reforms creates short-term revenue risks. The NRA was launched shortly after the procedural code was approved by parliament, and before all supplementary VAT, CIT, and PIT legislation was in place. Excise taxes will be collected by the customs administration from July 2006. Measures are being taken to reduce revenue losses from duty free sales ( $(9)$. Success of the expenditure program requires progress with structural reforms. The health sector is being reformed to prevent a recurrence of expenditure overruns. Plans for reforming the education sector would free up resources for teacher salaries but will require strong political commitment to implement. A planned employment cut in the central administration may also be difficult to implement. Further, there may be pressure to raise spending related to EU accession and defense beyond the amounts budgeted. To guard against fiscal slippage, the authorities are prepared to implement additional expenditure cuts (especially for non-road maintenance and operations) or revenue measures ( $(44)$.

\section{Incomes and Labor Market Policies}

\section{Incomes and labor market policies under the program aim to bolster} competitiveness and economic growth (\$12). The public sector will continue to signal wage restraint through tight budgetary and SOE wage bills, and the minimum wage will remain unchanged in the remainder of 2006. By end-March 2006, the authorities expect to reach agreement with the social partners to abolish the portability of seniority bonuses - a major hindrance to job mobility and employment creation - and increase work time flexibility. However, difficult discussions with the social partners suggest that this deadline is likely to slip at least in the case of the seniority bonuses. These measures will contribute to lowering unemployment and bolstering competitiveness. 


\section{Financial Sector Policies}

\section{The program aims at a further slowdown in bank credit growth for} macroeconomic and prudential reasons. As the CBA precludes the adoption of orthodox measures to slow credit growth, the BNB has extended the quarterly credit expansion limits introduced last year until the end of 2006. At the same time, it sharply raised the penalty deposits for banks exceeding the limits ( $(13)$. As the limits allow a constant nominal growth of credit per quarter, annual credit expansion is expected to decline from 32.3 percent (equivalent to 11 percent of GDP in flow terms) in 2005 to 17.5 percent ( 7 percent of GDP) in 2006. It is recognized that the measure restricts competition, risks being circumvented, and encourages disintermediation, but staff and authorities view steps to curb credit expansion as preferable to direct controls on capital inflows. A strategy for phasing out these measures in the context of EU accession will be discussed during the upcoming mission to conduct the third review and the Article IV consultation.

\section{The program contains additional measures to mitigate the risks related to the} rapid growth of credit to households. In response to the recent increase in overdue household loans, the BNB raised provisioning requirements for such loans, increased capital adequacy requirements for mortgages, and asked banks not to extend additional loans to households that do not meet the requirement of a minimum amount of income after taxes and debt service ( $(13)$. These marketbased measures are expected to make room under the credit growth limits for corporate borrowers, who are more easily able to find alternative sources of financing. Furthermore, in view of the observed correlation between household credit and consumer goods imports (Text Figure 3), these measures have macroeconomic advantages as well.

\section{Recognizing that the bank credit limits encourage nonbank lending, the} authorities intend to improve nonbank supervision ( $₫ 14)$. The new insurance law and an amendment to the pension law aim to modernize the risk management practices of the nonbank financial sector. The amendment to the pension law also removes the requirement

\footnotetext{
${ }^{8}$ The original intention was to impose the limits for the 12 months through March 2006.
} 
that pension funds invest a portion of their assets in government securities. Staff would have preferred to delay the lifting of this requirement until EU accession, but accepted that the macroeconomic benefit of such a delay would be modest. Leasing companies have started reporting their activities to the BNB. Bank-owned leasing companies are indirectly supervised because banks are supervised on a consolidated basis. The same will apply to companies owned by financial conglomerates following adoption of the financial conglomerates law.

\section{The authorities intend to continue reducing external public debt and to deepen}

domestic securities markets ( $(16)$. They have reduced external public debt through regular amortization and the early redemption of IMF and World Bank loans, but future such operations will be subject to reserve adequacy considerations. The program contains ceilings on the contracting and guaranteeing of external public debt (performance criterion). Notwithstanding a domestic financing surplus, the authorities intend to issue domestic government debt. Such borrowing supports development of the domestic securities market, while helping to absorb bank and pension fund liquidity.

\section{E. Other Structural Reforms}

\section{The program's structural reforms aim at improving the business climate by} lowering the cost of doing business, reducing corruption, and boosting competitiveness. Although the election delayed implementation of certain reforms, and the new government took time to formulate its priorities, reform momentum has recently picked up (\$16). A law on business registration is expected to be approved soon by parliament (prior action). Its early implementation is a performance criterion. Consistent with an EU requirement, constitutional amendments are likely to be approved soon to reform the judiciary and make it more accountable to parliament. The improved regulatory environment in the energy and water sectors paves the way for future privatizations and/or public-private partnerships. A number of companies are to be privatized in 2006, including three electricity generation companies that could not be sold by the previous government. Planned concessions for the operation of ports and airports will stimulate tourism and merchandise trade. Together, these reforms are expected to stimulate supply, but their precise impact is difficult to assess. Over time, they should help improve the current account. The impact of these reforms in the short run, however, is likely to be negative because the new investment encouraged by the improved business environment will be accompanied by capital goods imports.

\section{F. Program Conditionality and Waiver Requests}

22. As in 2005, the program includes four quantitative performance criteria. Three of these deal with the fiscal sector - a floor for the fiscal surplus, and ceilings on arrears and on contracting or guaranteeing non-concessional external debt. In addition, a ceiling has been set on the wage bill of selected state-owned enterprises. 


\section{Structural conditionality consists of one prior action, six performance criteria,} and eleven benchmarks (Text Table 7). As for the program relevance of the prior action and performance criteria:

- Approval by parliament and operationalization of the business registration legislation will help boost economic growth and reduce corruption.

- The new VAT law is crucial for revenue administration.

- Tax rates and bases need to be maintained to safeguard revenues.

- Preventing an increase in the monthly minimum wage limit is key to competitiveness and current account sustainability.

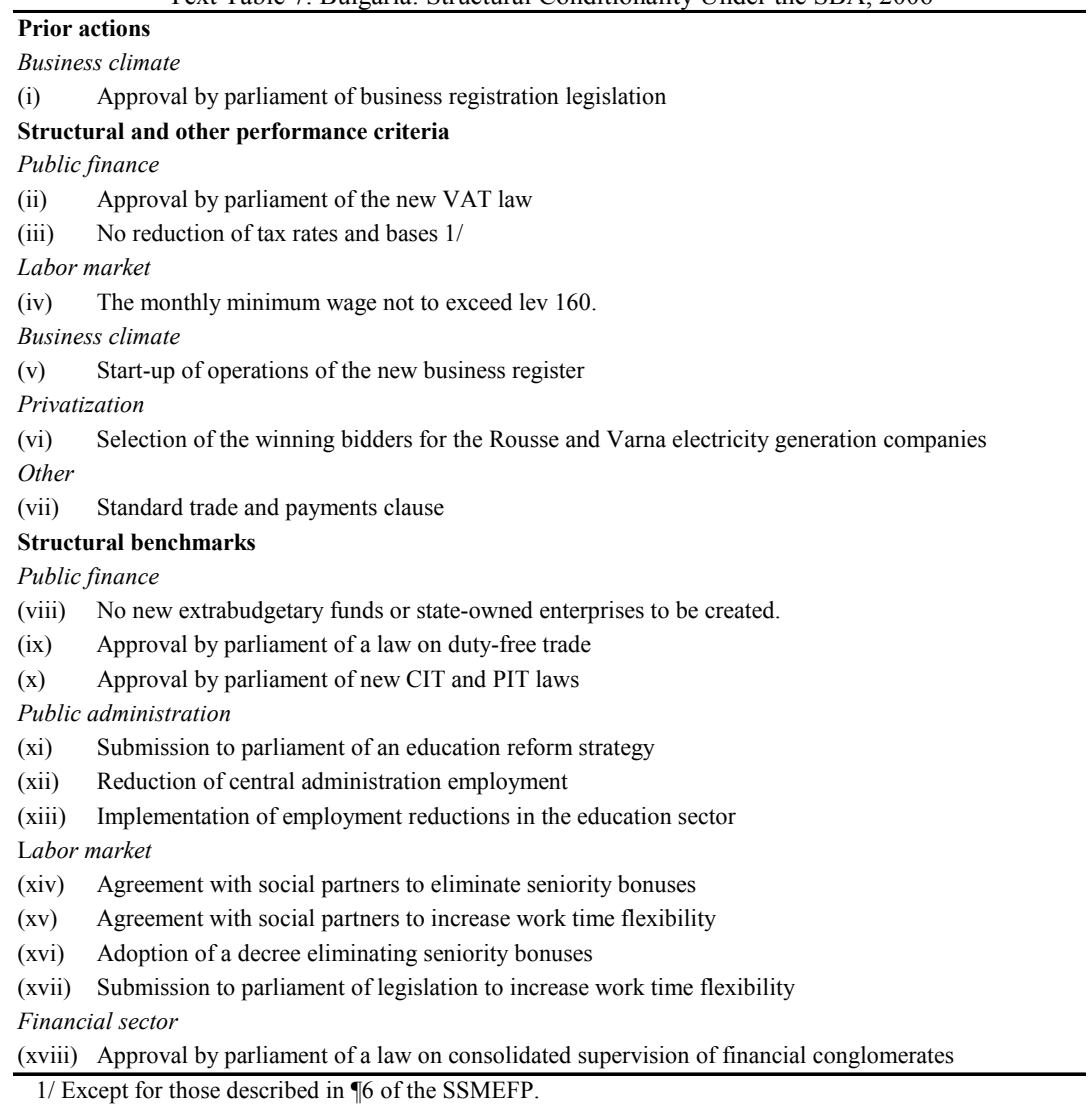

- Completion of the privatization deals contributes to economic growth and strengthens the fiscal position.

\section{It is proposed to change the conditionality of the first review in the following respects:}

- To convert the missed structural performance criterion for the privatization of three electricity generation companies into a performance criterion to select winning bidders for two companies while the court case of the third company is pending.

- To split the benchmark for parliamentary approval of new PIT, CIT and VAT laws into a performance criterion for the VAT law and a benchmark for the PIT and CIT laws.

- To reschedule the benchmarks dealing with labor market reform, consistent with the new government's consensual approach to labor relations. 
- The authorities remain committed to enacting the constitutional amendment to allow municipalities to set their own tax rates, but could not commit to a time schedule in view of the broad political support required for such an amendment.

- Because of the delay in completing the second review, the authorities are requesting to combine the third and fourth reviews and to complete the combined review by September 5, 2006. On current plans, this review could be brought to the Executive Board in early August 2006, together with the 2006 Article IV consultation.

\section{G. Data Issues}

25. Data provision and quality are generally sufficient for program monitoring, but the authorities are committed to further improve the quality of statistics ( $\ 17$ and Appendix III). The analysis of the rapid deterioration of the current account would have benefited from more up-to-date and detailed national accounts and balance sheet data. The authorities intend to address these gaps and may request technical assistance in statistics.

\section{STAFF Appraisal}

26. Policy implementation under the 2005 program has once again been strong on the macroeconomic side, and mixed on the structural front. The authorities' efforts to meet their commitments in the fiscal area by maintaining a cautious fiscal stance in response to higher than expected tax collections have been commendable. The authorities have also been successful in slowing credit expansion in line with the program, although the end-year target was missed due to a temporary credit spike. By contrast, implementation of structural reforms was again delayed - in part due to the elections and preoccupation with EU accession - and several structural performance criteria and benchmarks were breached. On a positive note, however, the parliamentary approval of its procedural code allowed the long planned launching of the NRA at the start of 2006.

27. Notwithstanding satisfactory macroeconomic policy implementation, a sharp widening of the private saving-investment imbalance caused the external current account deficit and inflation to be much higher than envisaged. Exogenous factors such as severe floods, higher oil and administered prices, and restructuring in the metals sector contributed to this outcome. However, based on available indicators, competitiveness appears to have been maintained, but will need to be watched carefully. Imports of investment goods financed by foreign direct investment were higher than projected, suggesting the prospect of higher growth ahead. Economic growth in 2005 remained strong, and would have been higher in the absence of the exogenous factors.

28. Rising excess private demand and exogenous shocks have increased external vulnerabilities beyond the levels envisaged under the 2005 economic program. Although some of the adverse shocks are likely to be temporary, the authorities face the challenge of adjusting their policies to reduce the external current account deficit and stabilize, and eventually reduce, the external debt ratio and build cushions against possible future 
contingencies. An appropriate policy mix would therefore include measures to restrain demand, bolster competitiveness, and expand supply.

29. The limited effectiveness of the credit measures implemented thus far and the risks of continued rapid credit growth magnify the policy challenges facing Bulgaria. The open capital account has permitted qualified businesses to access credit abroad while allowing domestic banks to redirect their credit to households. At the same time, while increased financial intermediation is welcome from a structural perspective, the recent rate of credit expansion has been uncomfortably high on macroeconomic and prudential grounds.

\section{The authorities' policies for $\mathbf{2 0 0 6}$ provide an appropriate response to this}

challenge. The measures to further tighten the fiscal stance will contribute to reducing excess domestic demand, as should the credit measures that have been strengthened and redirected to households, which have less access to foreign capital markets. In addition, the measures are helpful to strengthen banks' balance sheets. The restrained incomes policy and the reduction of nonwage labor costs are apt to strengthen further competitiveness in the currency board environment. Equally important for easing the excess demand pressures, however, is the authorities' commitment to structural reforms aimed at increasing the productive capacity of the economy.

31. The proposed fiscal effort is commendable. It is an appropriate response to the widening private saving-investment gap and sends a clear signal of the authorities' commitment to prudent macroeconomic policies in the context of the currency board arrangement. It is important now for the authorities to make every effort to reach their revenue target by ensuring that the ongoing restructuring of revenue administration does not result in collection losses and by introducing limits on duty free sales. In this regard, the closure of duty free outlets, especially those outside border areas, should also be a priority. Even more important are efforts to restrain expenditure to the agreed level by enforcing the cuts of discretionary spending, reducing central administration employment as envisaged, resisting pressure for higher defense spending, and implementing reforms to health and education in an expenditure neutral fashion. The targeted fiscal surplus, privatization receipts, and the most recent advance repurchase to the Fund should contribute to a further significant reduction in the public debt ratio. Future debt reduction operations should, however, be mindful of the need for maintaining an adequate international reserve cover. The authorities' commitment to strengthen fiscal policy further if the current account deficit does not improve as projected during 2006 is important and welcome.

32. Looking ahead, there is a need for greater fiscal transparency. The 2007 budget should be prepared on the basis of a realistic revenue estimate, with a transparent accounting of expected receipts of EU funds and their spending and without within-year caps on discretionary expenditure.

33. Notwithstanding their well-known drawbacks, the extension of the bank credit expansion limits should contribute to current account adjustment. As households have limited alternatives to bank financing in the short term, the emphasis on prudential measures 
to dampen household credit should give greater traction than in the past in slowing aggregate private sector borrowing. Additionally, these measures should strengthen banks' balance sheets. However, the currency board arrangement and an open capital account circumscribe the effectiveness of the measures taken beyond the near term. These measures have contributed to the rapid growth of partially unsupervised nonbank intermediation and foreign borrowing. Moreover, under the "single passport" EU banks will obtain unrestricted access to the domestic credit market upon EU accession. To give domestic banks a level playing field and remove the distortions resulting from these measures, the latter will need to be phased out after this year. As the measures stimulate nonbank lending, the authorities' recent steps to improve reporting and the regulatory framework of nonbank financial intermediaries are welcome. However, the authorities should consider further steps to strengthen nonbank supervision.

\section{The program relies appropriately on structural reforms to enhance supply and}

competitiveness. The adoption of the business register law needs to be followed up by its early implementation to speed up registration, lower its cost and reduce corruption. The reduction in nonwage labor costs is a welcome boost to competitiveness which should be followed up by the planned annual reductions in the employers' share in social contributions during 2007-09. To further enhance the business climate, the planned measures to improve the functioning of the labor market need to be adopted. The ongoing judicial reform should provide better protection of property rights and speedier contract enforcement while reducing corruption. Finally, privatization of state assets and concessioning of ports and airports should improve efficiency and ease infrastructure bottlenecks.

\section{Bulgaria's increased reliance on capital imports is likely to help achieve more} rapid real income convergence with the $\mathbf{E} \mathbf{U}$. This prospect is welcome, but it also creates risks. Credit financed consumption smoothing in the expectation of higher future incomes and investment opportunities offering high rates of return underlie the structurally weak current account position and have raised external debt. While the resulting vulnerability indicators lie beyond the conventional comfort zones and are a source of concern, there are also a number of mitigating factors in Bulgaria's case: a high reserve cover of maturing short-term liabilities and prospective imports, a low net external debt ratio, a solid fiscal position, a well capitalized and highly provisioned banking system, strengthened prudential regulations and supervision, much increased transparency, approaching EU accession, and continued market confidence as expressed in a low sovereign risk spread. In addition, the large imports of investment goods and the prospect of a reversal of at least some of the exogenous shocks augur well for higher growth and a lower current account deficit in the future.

\section{Accordingly, staff proposes completion of the second review on the basis of the} policies proposed by the authorities. Staff also supports granting the three requested waivers - in two instances because the promised action has since been taken, and, in the case of the partially implemented privatization criterion, because the delay was beyond the control of the authorities, who have proposed an alternative course of action to observe the 
performance criterion. Finally, staff supports the authorities' request to combine the third and fourth reviews. This is justified by the delay in completing the present review and will not lead to less monitoring by the Fund. It is planned to complete the combined review in early August 2006. 
Figure 1. Bulgaria: Real Sector Developments, 2003-05

(In percent, unless otherwise noted)

Growth of domestic demand has been vigorous, but the external sector has been a drag ...

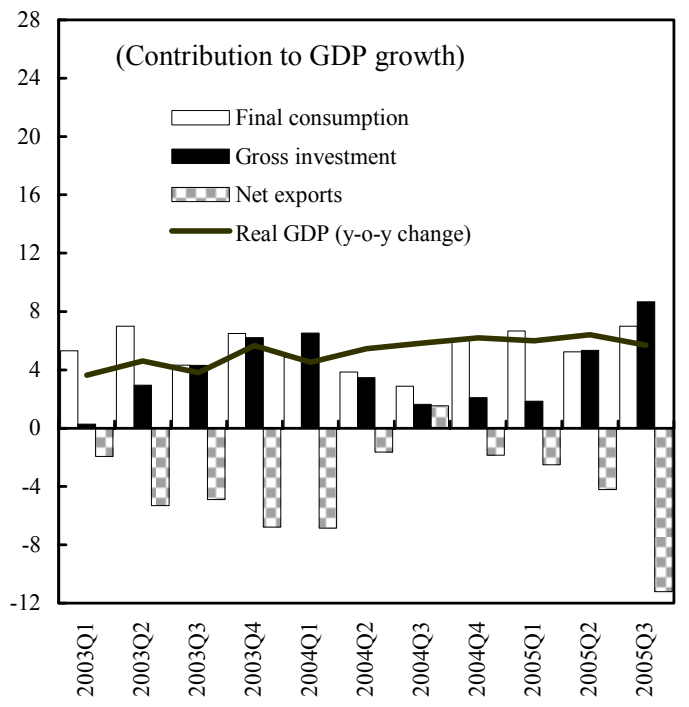

Both headline and core inflation have increased ...

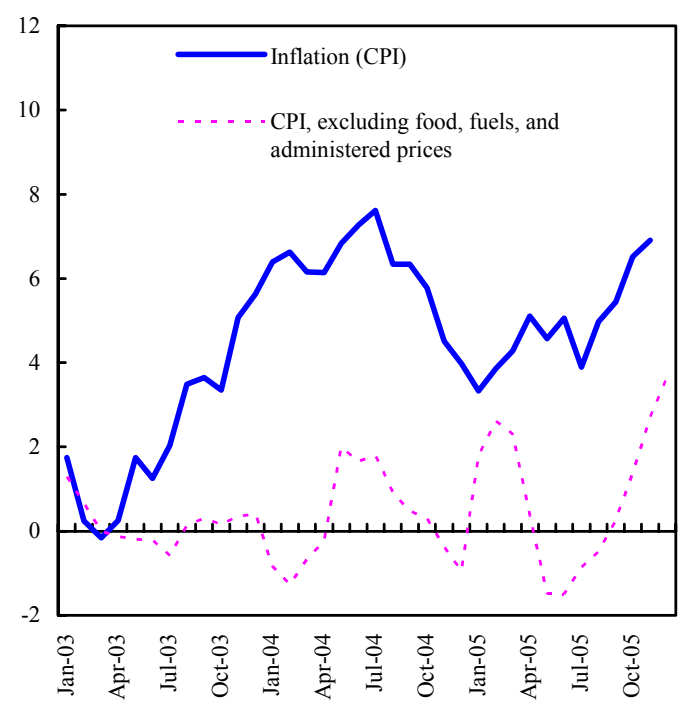

... industry and services expanded rapidly, but agriculture contracted sharply mainly due to floods.

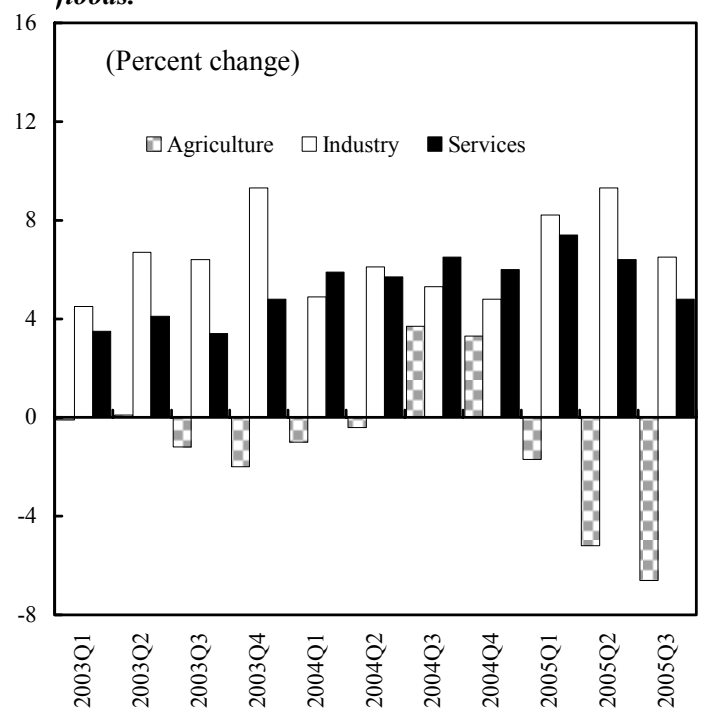

\section{... but real wage increases remained modest and unemployment continued to fall.}

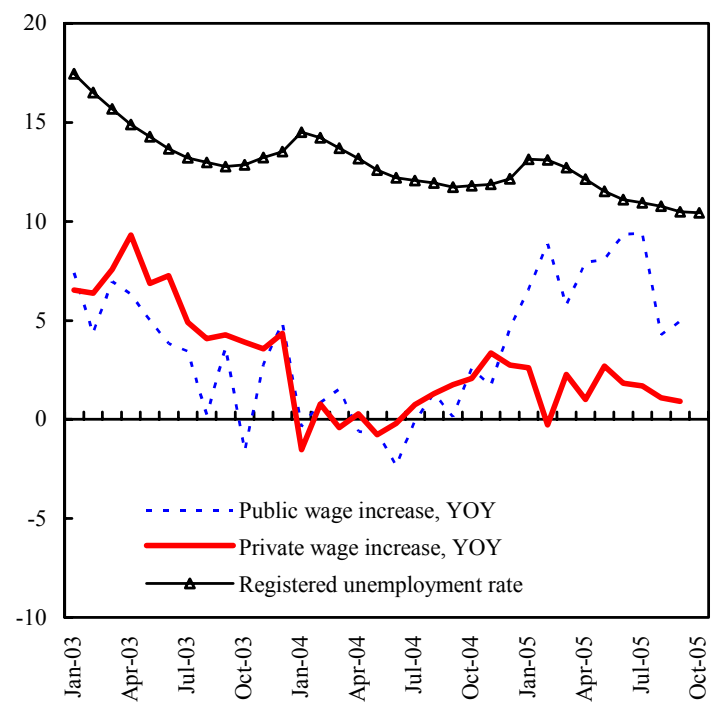

Sources: Bulgarian authorities; and Fund staff estimates. 
Figure 2. Bulgaria: Balance of Payments Developments

The current account deteriorated sharply in 2005 ...

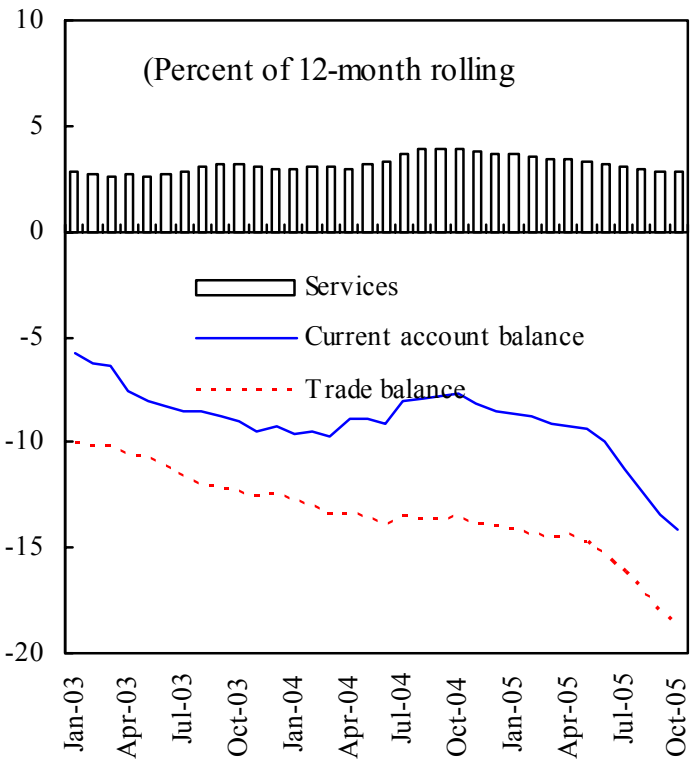

Export and import prices rose rapidly, and the terms of trade dropped modestly.

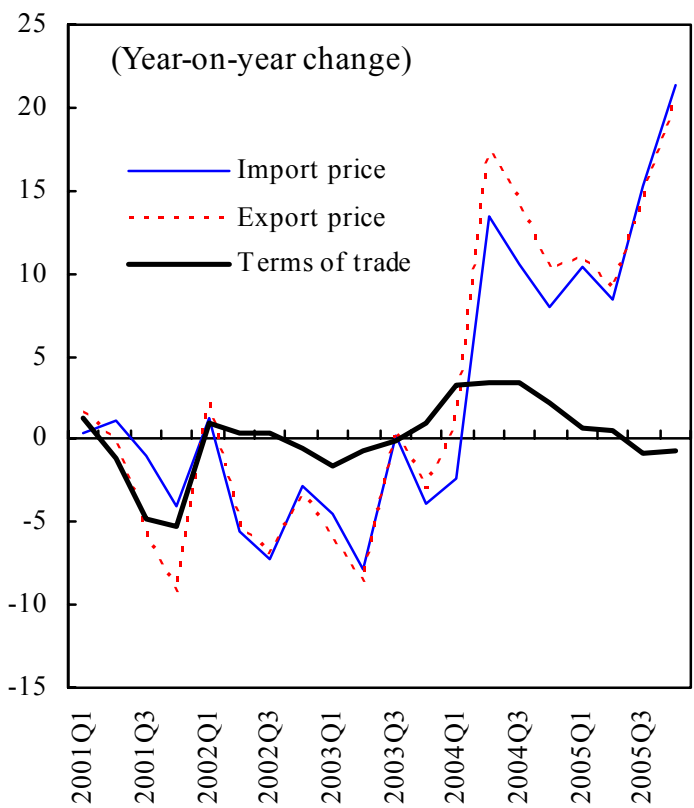

... and foreign debt increased, mainly due to rising bank and FDI-related intercompany loans.

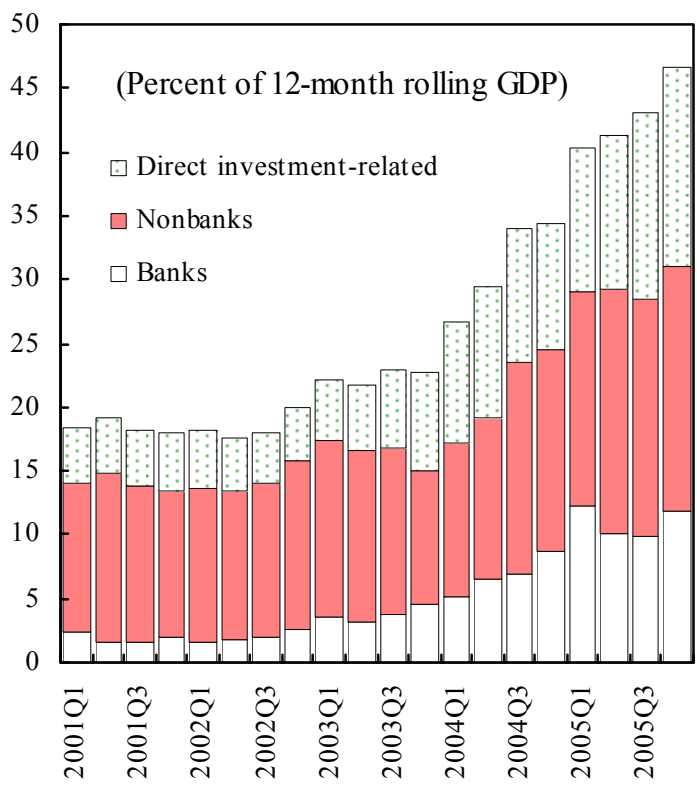

Rising exports also contributed to imports of raw materials.

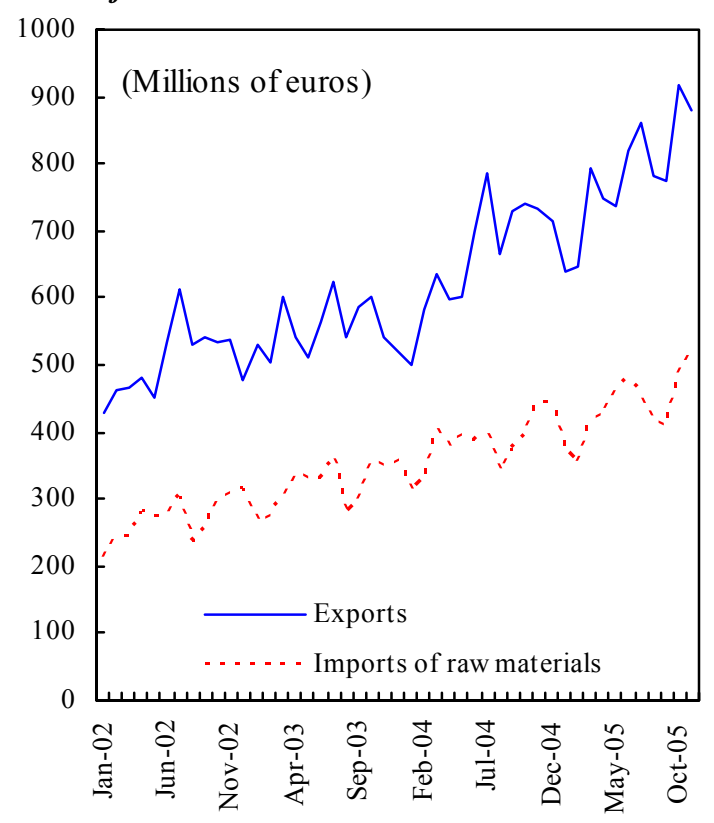

Sources: Bulgarian authorities; and Fund staff estimates. 
Figure 3. Bulgaria: Competitiveness

A decline in relative unit labor costs raised competitiveness despite the impact of the $€ / \$$ exchange rate on the NEER.

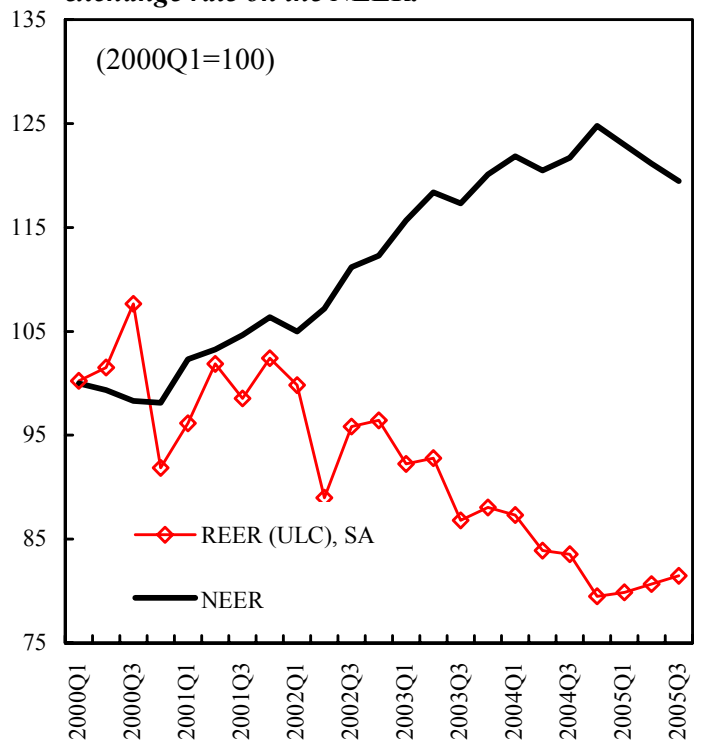

... but Bulgaria's share in EU imports continued to rise ...

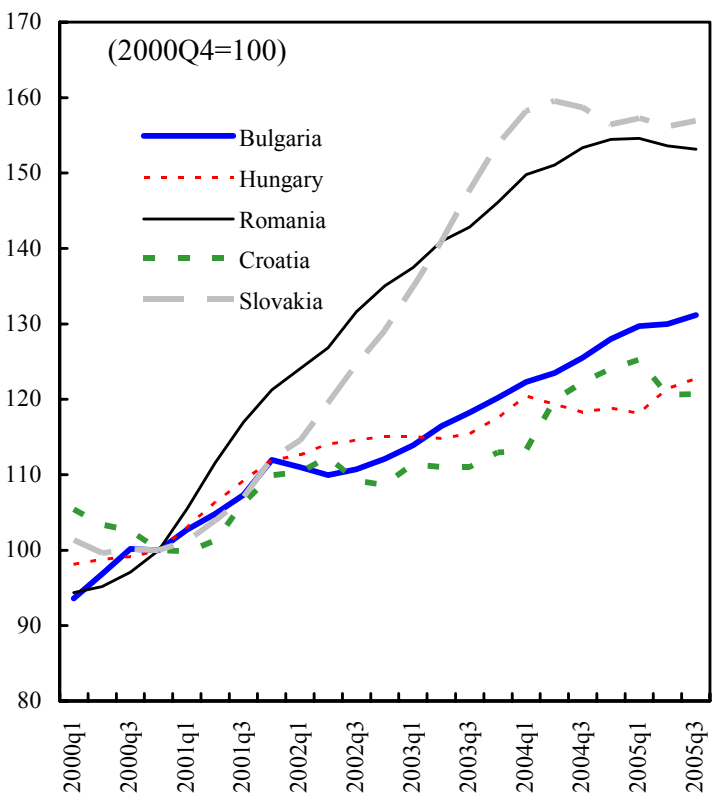

Export volume growth slowed during 2005 ...

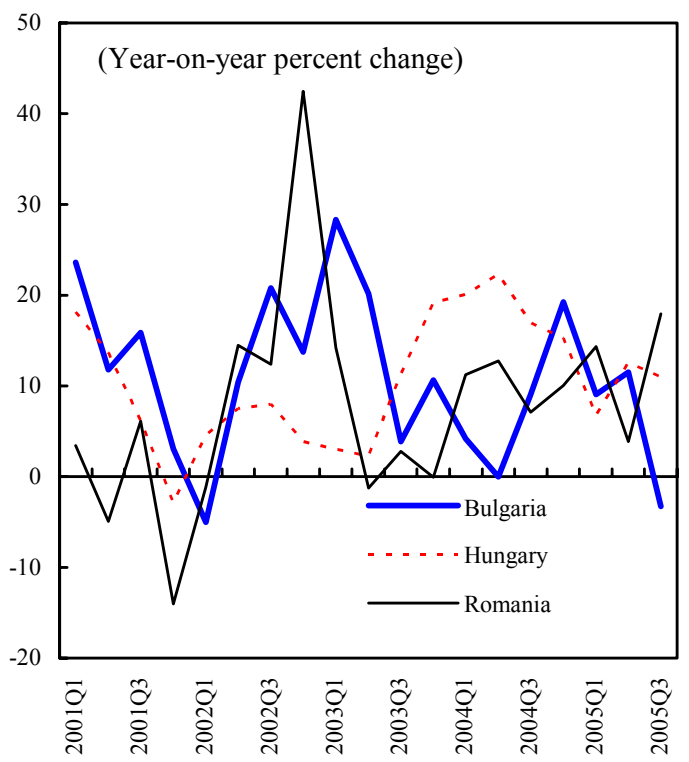

... especially in the new EU member states.

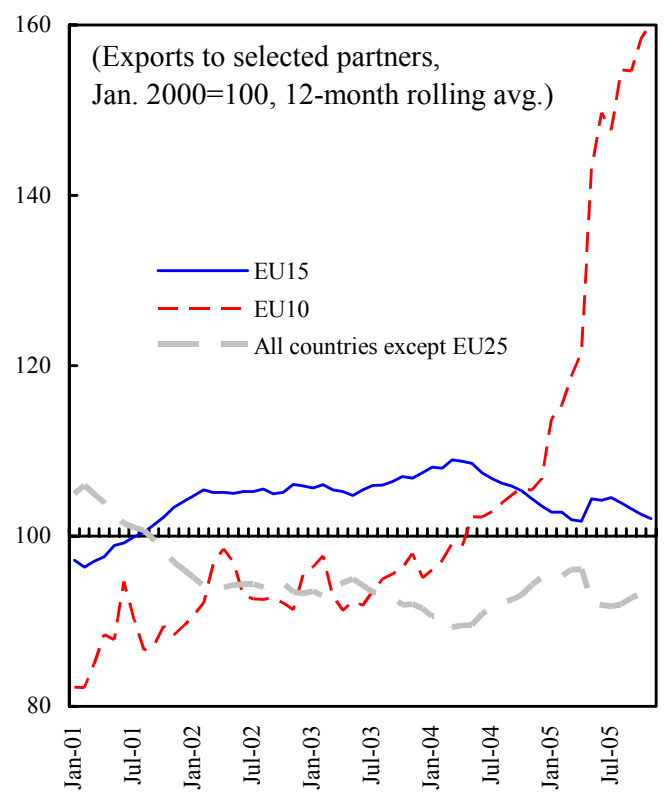

Sources: Bulgarian authorities; and Fund staff estimates. 
Figure 4. Bulgaria: Fiscal Sector Developments

(In percent of GDP)

Revenues are buoyant and expenditures are contained ...

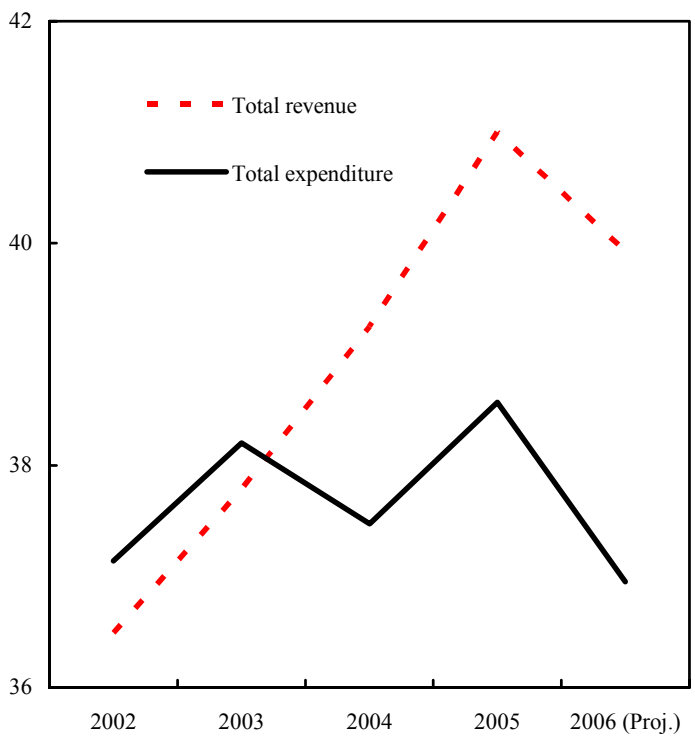

Public capital expenditure has increased and is projected to stabilize ...

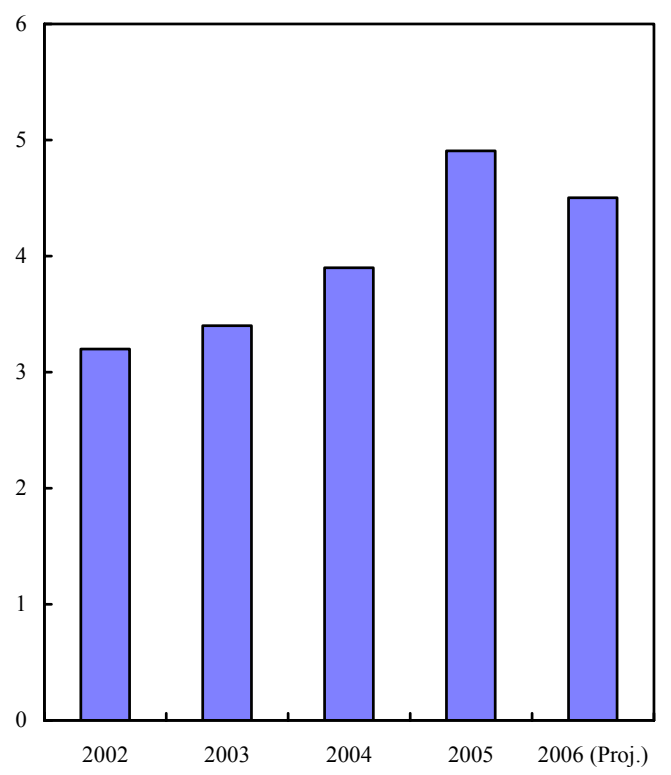

... leaving space for increasing surpluses.

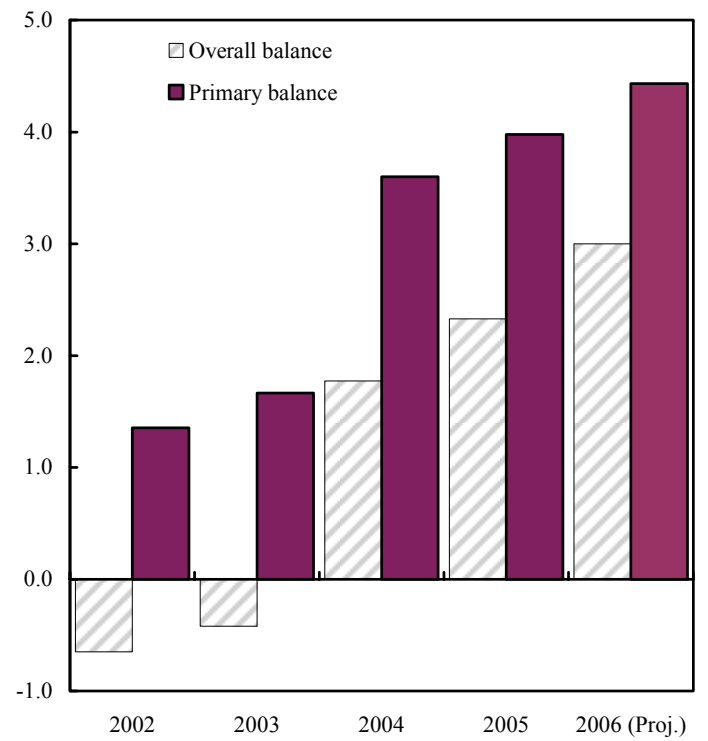

... while budget surpluses and privatization have enabled reductions in the public external stock of debt.

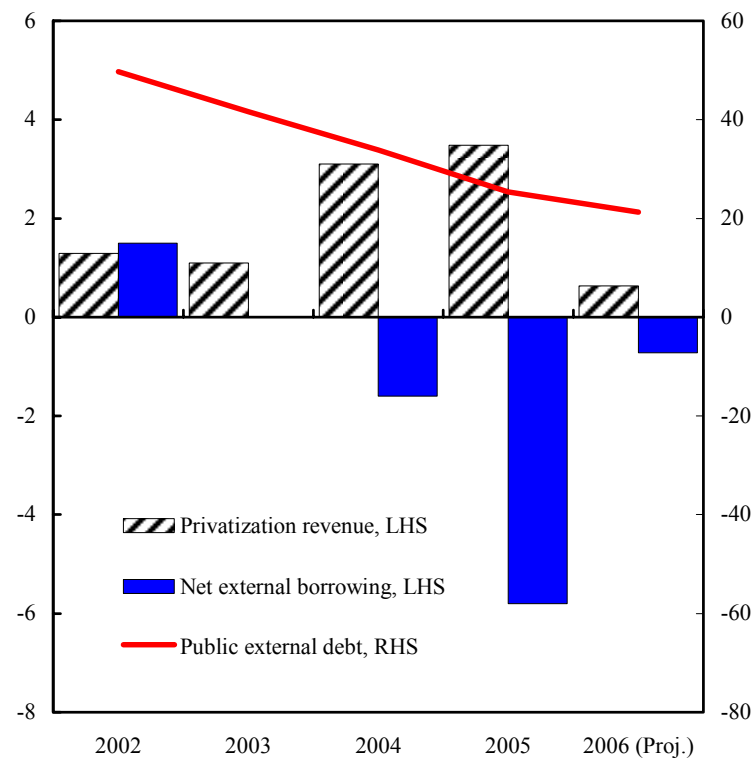

Sources: Bulgarian authorities; and Fund staff estimates. 
Figure 5. Bulgaria: Financial Sector Indicators

The timing of the credit measures contributed to a spike in enterprise credit ...

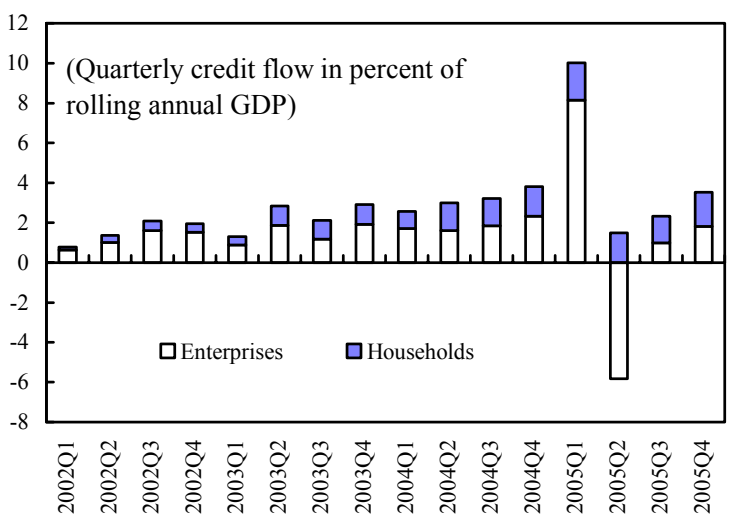

Credit growth slowed in 2005 and is projected to slow further in 2006, while banks rebuild their NFA.

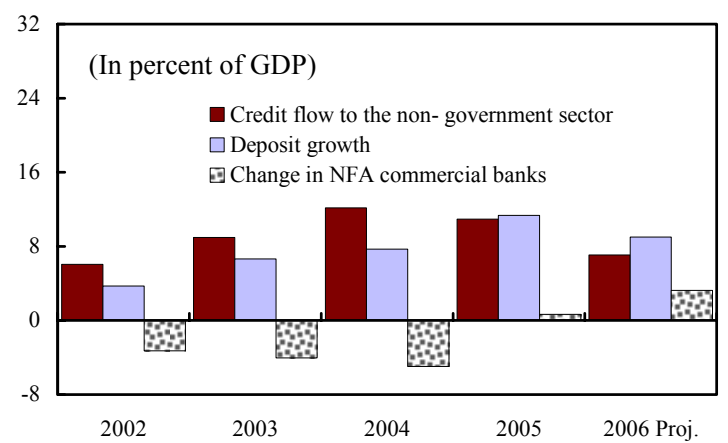

The stock market index stabilized but real estate prices continued their upward trend ...

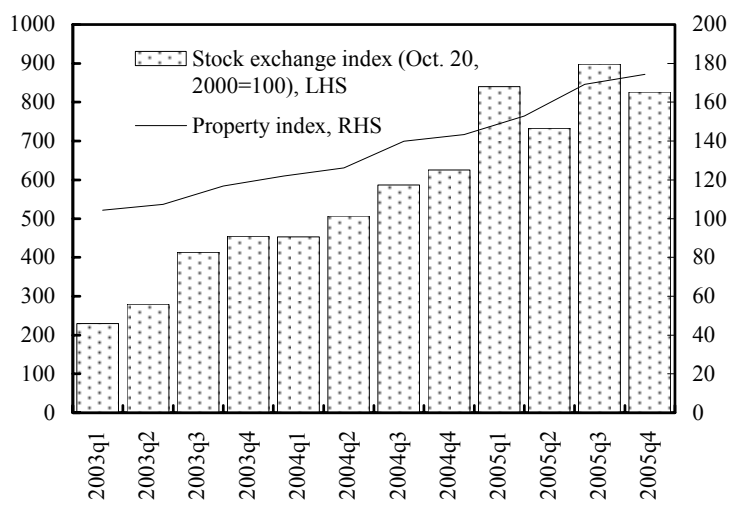

... and a concomitant temporary spike in M3 growth.

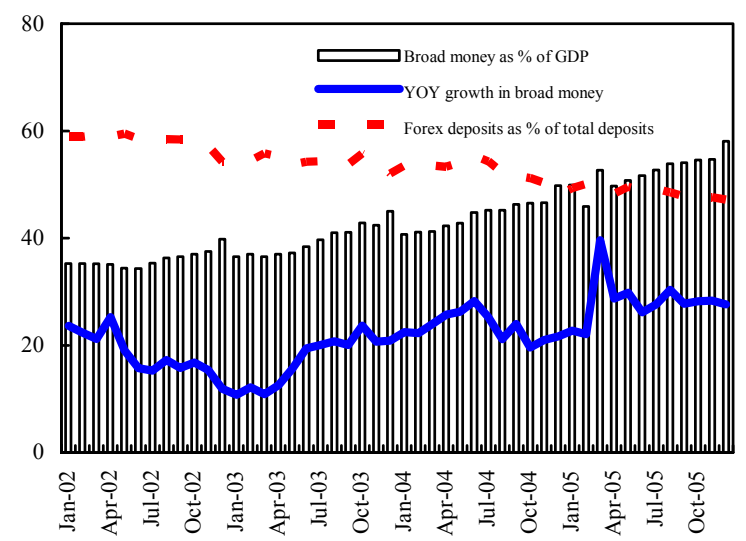

Lending rates continued their downward trend while deposit rates stabilized.

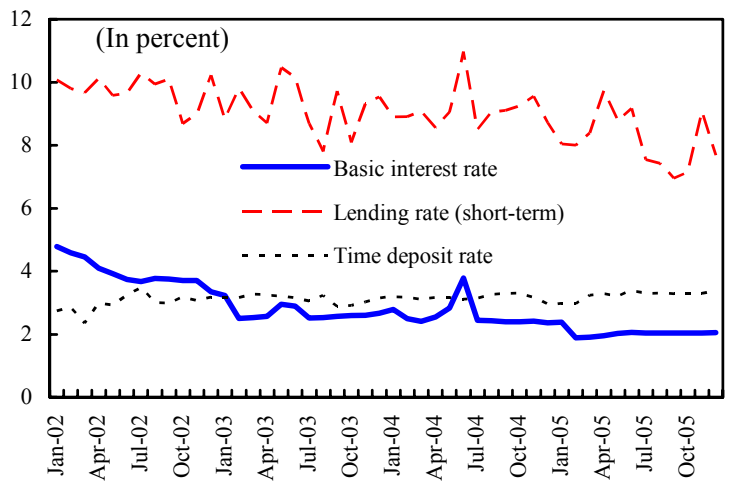

... and narrowing sovereign bond spreads indicate continued investor confidence.

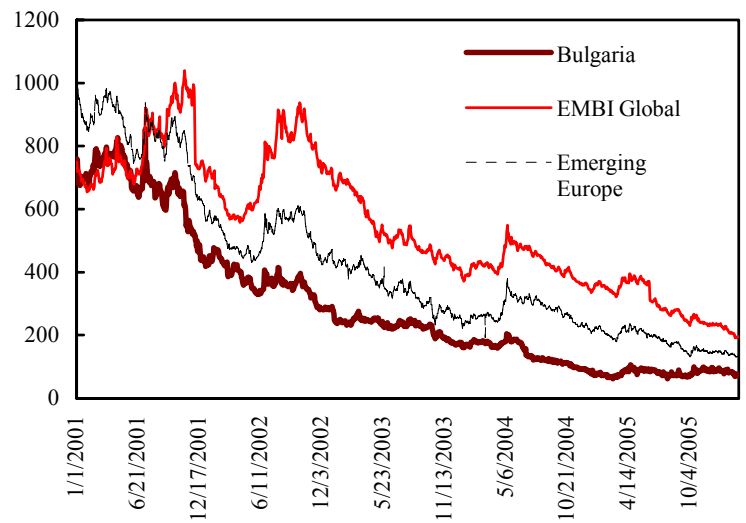

Sources: Bulgarian authorities; and Fund staff estimates. 
Figure 6. Bulgaria and Comparator Countries, Selected Macroeconomic Indicators, 2004 and 2005 (in percent of GDP, unless otherwise indicated)

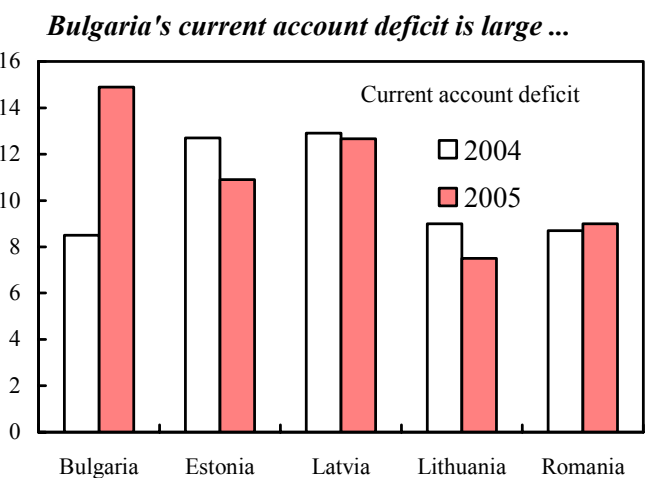

FDI contributes to rising investment ratios ...

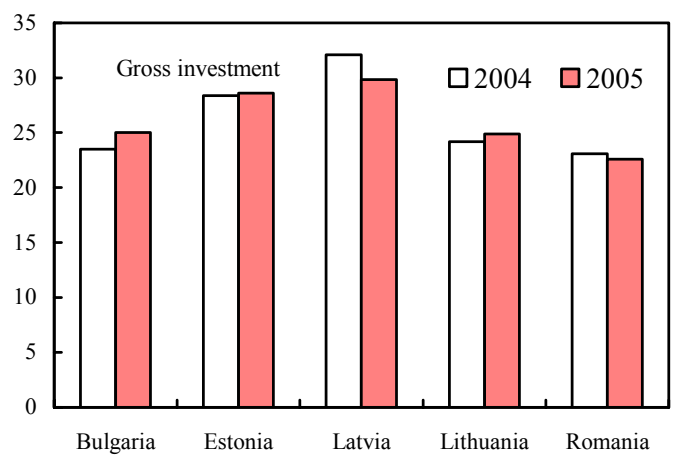

Despite Bulgaria's comparatively strong fiscal position ...

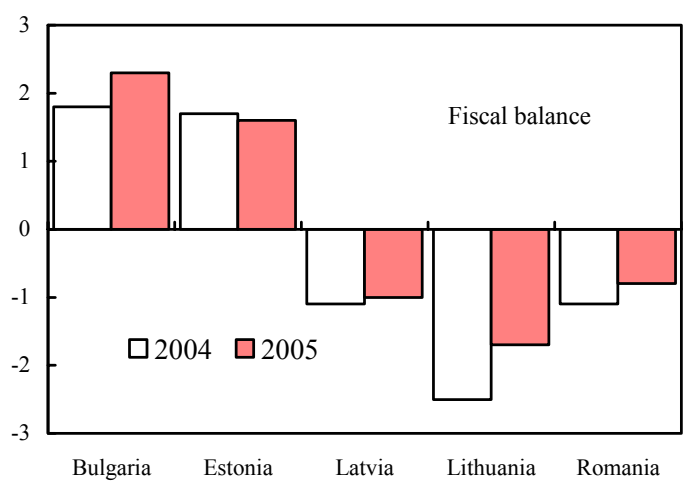

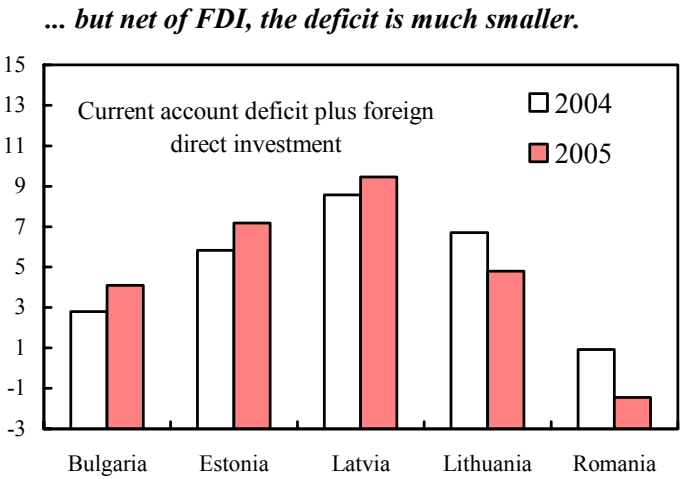

... notwithstanding comparatively modest growth.

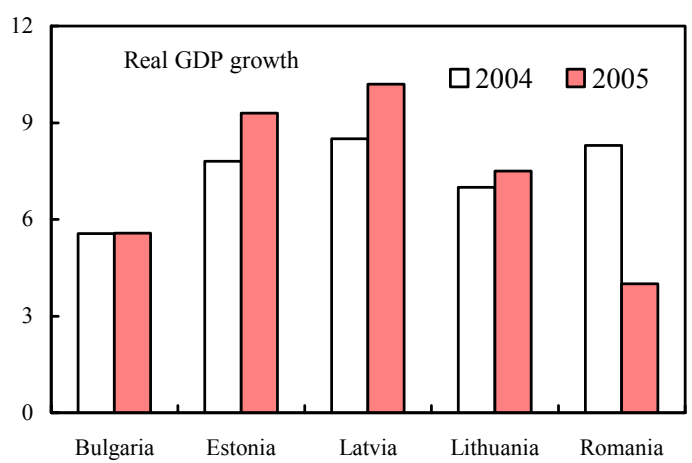

... its net intertnational investment position remains negative.

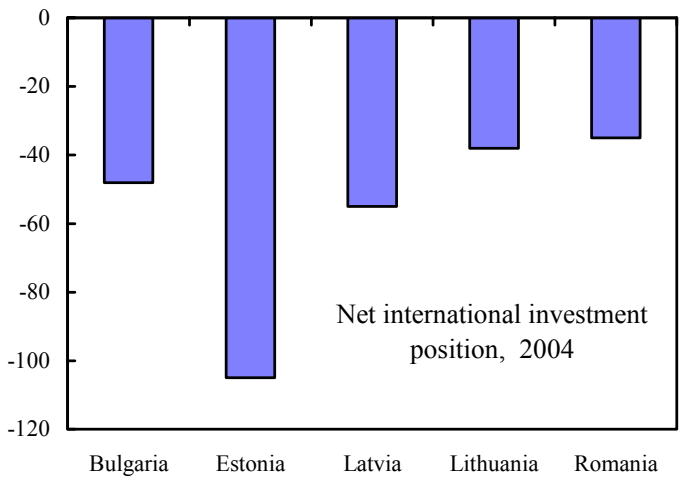

Sources: WEO and country authorities, various years. 
Figure 7. Bulgaria: Baseline Medium-Term Projections, 2001-2011 1/

(In percent of GDP, unless otherwise indicated)

GDP growth is trending up while inflation is projected to decline.

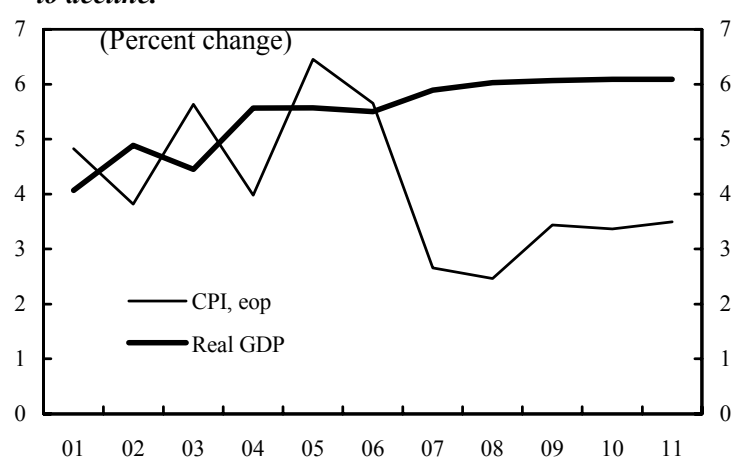

... and the current account deficit is projected to narrow.

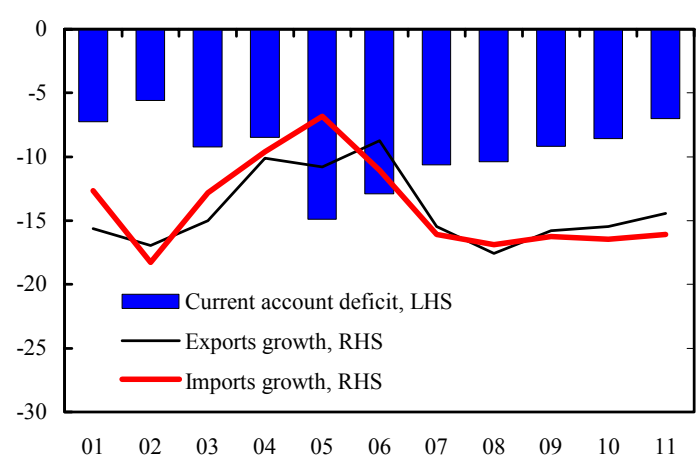

The fiscal surplus will decline ...

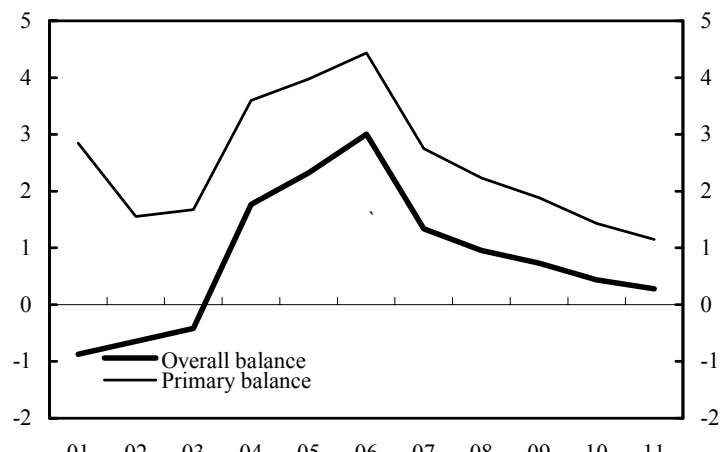

$\begin{array}{lllllllllll}01 & 02 & 03 & 04 & 05 & 06 & 07 & 08 & 09 & 10 & 11\end{array}$
Investment continues to increase modestly while savings grow rapidly ...

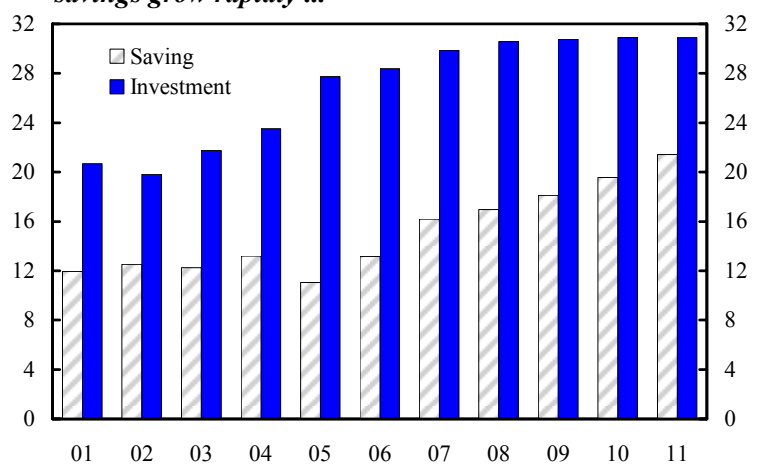

External debt will decline after 2006 and debt service will drop after the impact of 2005-06 prepayments.

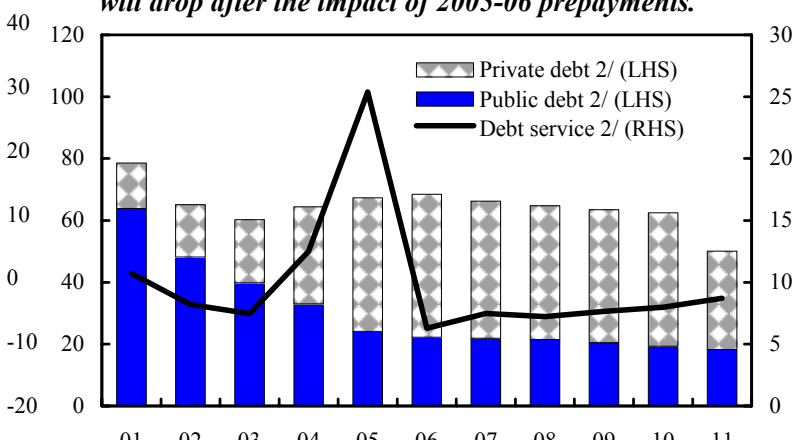

... but public debt will drop further.

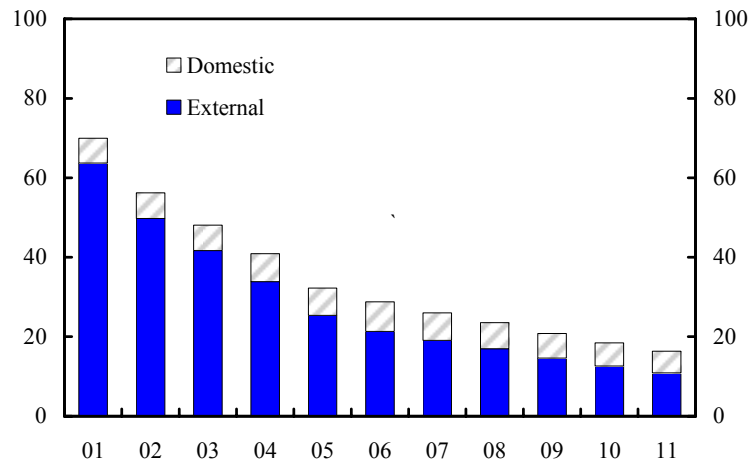

Sources: Bulgarian authorities; and Fund staff estimates and projections.

1/ 2006 onward; projections.

2/ Projections include assumptions on disbursements related to debt not already contracted. 
Figure 8. Bulgaria: External Debt Sustainability: Bound Tests 1/

(External debt in percent of GDP)

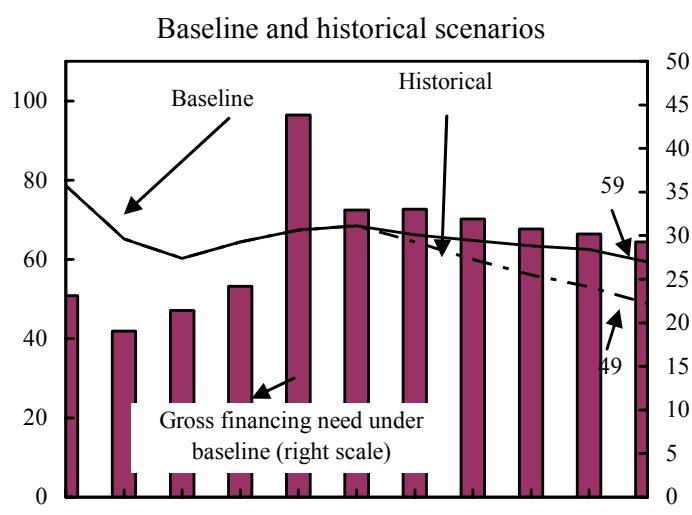

20012002200320042005200620072008200920102011

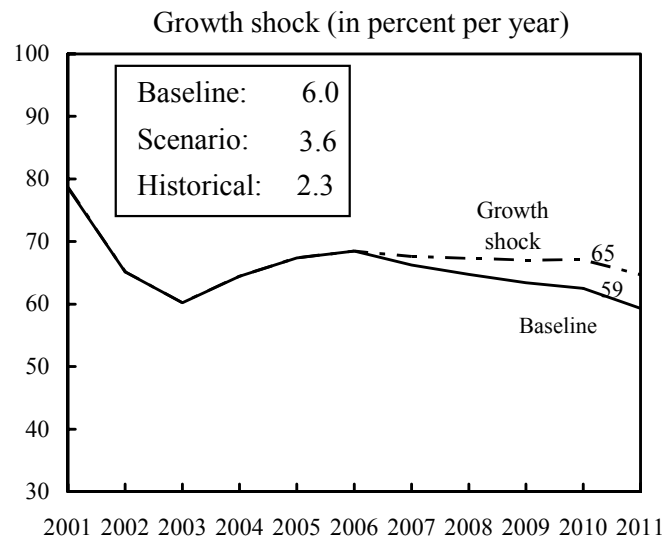

Combined shock 2/

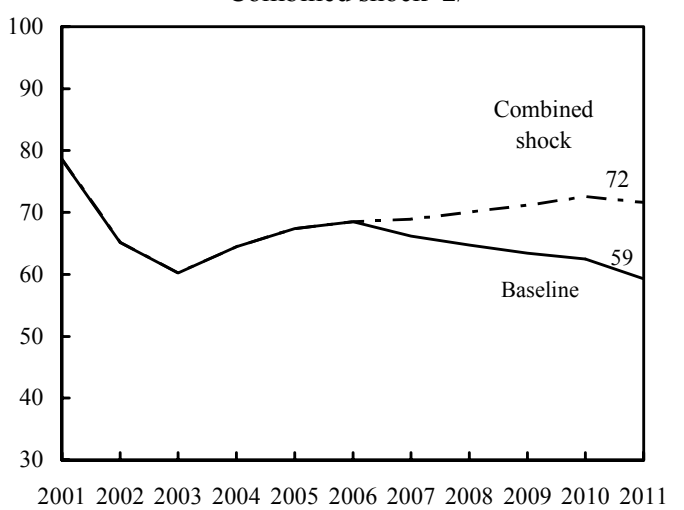

Interest rate shock (in percent)

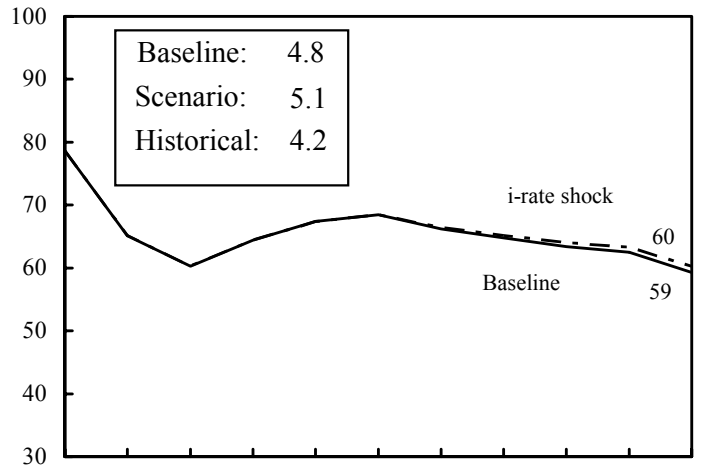

2001200220032004200520062007200820092010201

Non-interest current account shock (in percent of GDP)

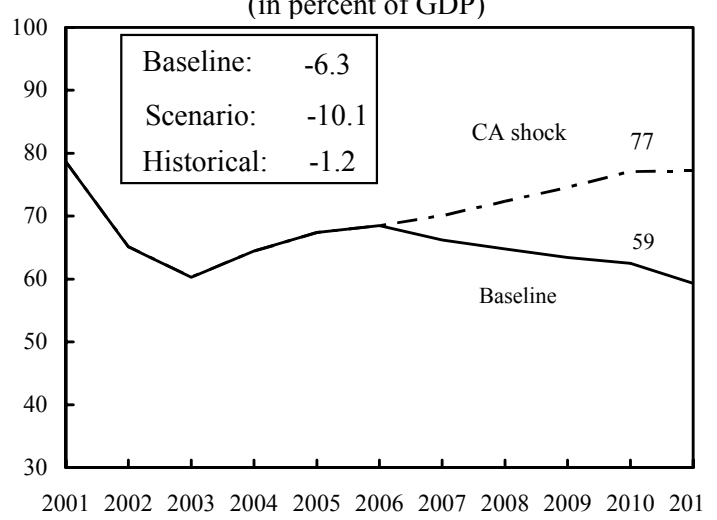

Sources: International Monetary Fund, Country desk data, and staff estimates.

1/ Shaded areas represent actual data. Individual shocks are permanent one-half standard deviation shocks.

Figures in the boxes represent average projections for the respective variables in the baseline and scenario being presented. Ten-year historical average for the variable is also shown.

2/ Permanent 1/4 standard deviation shocks applied to real interest rate, growth rate, and current account balance.

3/ One-time real depreciation of 30 percent occurs in 2006. 
Figure 9. Bulgaria: Public Debt Sustainability: Bound Tests 1/

(Public debt in percent of GDP)

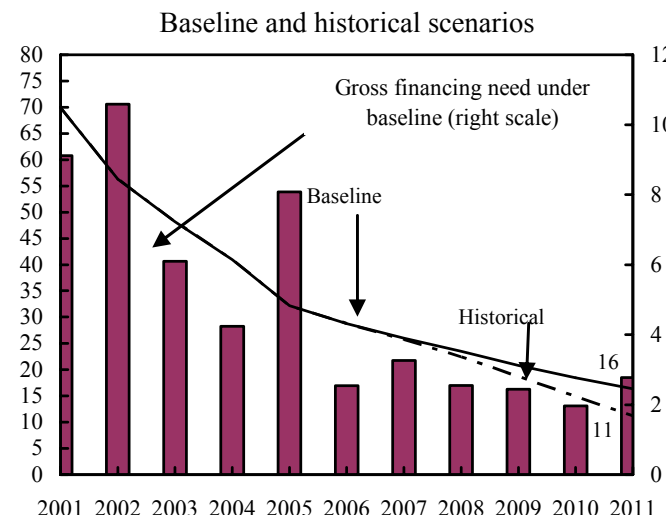

Growth shock (in percent per year)

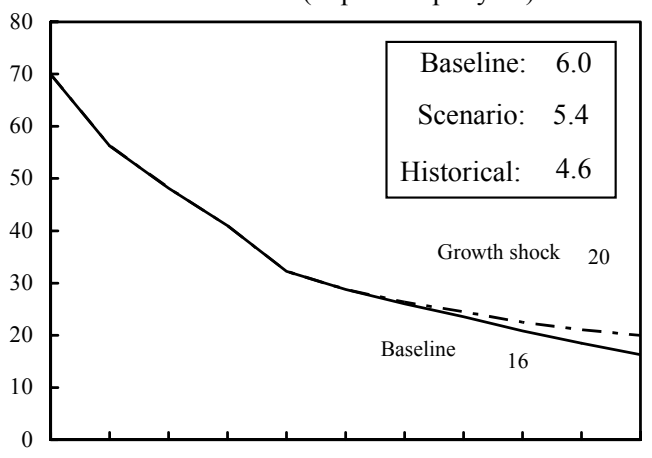

20012002200320042005200620072008200920102011

Combined shock $2 /$

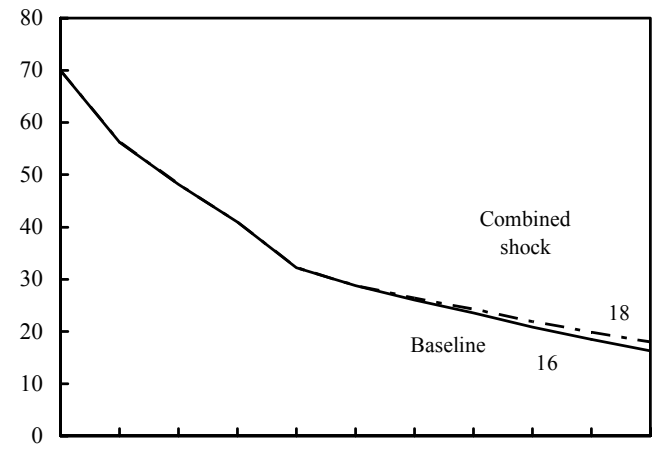

20012002200320042005200620072008200920102011

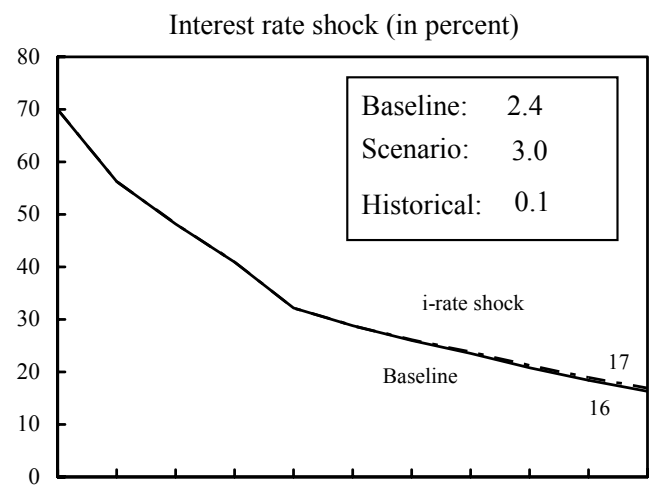

20012002200320042005200620072008200920102011

Primary balance shock (in percent of GDP) and no policy change scenario (constant primary balance)

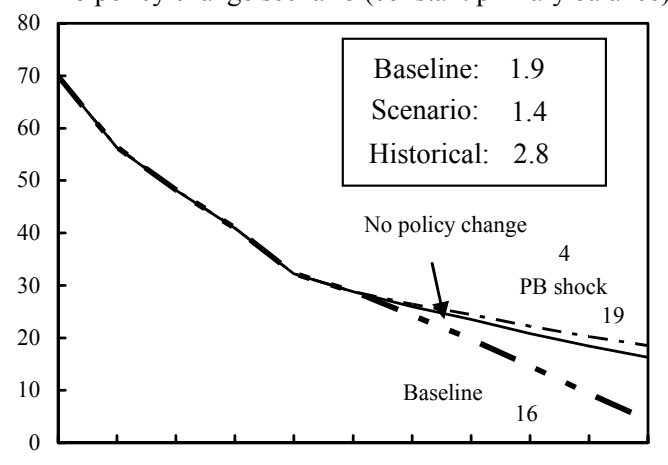

20012002200320042005200620072008200920102011

Sources: International Monetary Fund, Country desk data, and staff estimates.

1/ Shaded areas represent actual data.Individual shocks are permanent one-half standard deviation shocks. Figures in the boxes represent average projections for the respective variables in the baseline and scenario being presented. Ten-year historical average for the variable is also shown.

2/ Permanent 1/4 standard deviation shocks applied to real interest rate, growth rate, and primary balance.

3/ One-time real depreciation of 30 percent and 10 percent of GDP shock to contingent liabilities occur in 2006, with real depreciation defined as nominal depreciation (measured by percentage fall in dollar value of local currency) minus domestic inflation (based on GDP deflator). 
Table 1. Bulgaria: Proposed New Schedule of Purchases Under the Stand-By Arrangement

\begin{tabular}{|c|c|c|c|}
\hline \multirow[b]{2}{*}{ Date } & \multicolumn{2}{|c|}{ Amount of Purchase 1/ } & \multirow[b]{2}{*}{ Conditions } \\
\hline & In millions of SDRs & In percent of quota & \\
\hline August 6, 2004 & 12.0 & 1.9 & Board approval of Stand-By Arrangement \\
\hline December 15, 2004 & 11.0 & 1.7 & Observance of end-September 2004 performance criteria \\
\hline March 15, 2005 & 11.0 & 1.7 & Observance of end-December 2004 performance criteria and completion of first review \\
\hline September $15,20052 /$ & 22.0 & 3.4 & Observance of end-June 2005 performance criteria \\
\hline December 15, 2005 & 22.0 & 3.4 & Observance of end-September 2005 performance criteria and completion of second review \\
\hline June 13, 2006 & 11.0 & 1.7 & Observance of end-March 2006 performance criteria and completion of third review \\
\hline September 5, $20063 /$ & 11.0 & 1.7 & Observance of end-June 2006 performance criteria \\
\hline Total & 100.0 & 15.6 & \\
\hline
\end{tabular}

Source: Fund staff calculations.

1/ Assuming maximum proposed access. The authorities plan to treat the arrangement as precautionary and do not intend to make any purchases.

2/ Includes access originally proposed to be available on meeting the end-March performance criteria. These performance criteria were to be set at the time of the first review, earlier envisaged to be completed before end-March 2005.

3 / Brought forward to include within the program period. 
Table 2. Bulgaria: Observance of Structural Conditionality Under the Stand-By Arrangement in 2005 1/

\section{Conditionality Met}

1. Ministry of Finance to prepare an economic classification of consolidated general, central and local government expenditures.

2. Approval of legal provisions requiring leasing companies to report regularly their ownership structure and financial operations.

3. No imposition of new or intensification of existing restrictions on the making of payments and transfers for current international transactions, nor introduction or modification of multiple currency practices, nor conclusion of any bilateral

payments arrangements that are inconsistent with Article VIII of the IMF Articles

of Agreement, nor imposition or intensification of any import restrictions for

balance of payments purposes, nor accumulation of any external payments arrears.

\section{Conditionality Not Met (Implemented Partially or with Delay)}

1. Selection of winning bids for the sale of three large thermal electricity companies (Varna EAD, Ruse EAD, and Bobov Dol EAD).

2. Adoption by parliament of the NRA procedural code.

3. Incorporation of all lev-denominated expenditure accounts of the judicial system in the budgetary payments system (SEBRA).

4. Submit to parliament draft legislation to transfer business registration to a nonjudicial administrative body and establish a unified national electronic register with limited judicial oversight and simplified administrative procedures.

5. Approval by parliament of new PIT, CIT, VAT and excise tax laws required to make the NRA operational.

6. Government to update the property tax valuations.

7. No new extrabudgetary funds or state-owned enterprises to be created during the program period.
Type 2/

SB - September 30, 2005

SB - December 31, 2005

Other PC - Continuous

\section{Previous Status 2/}

SPC - September 30, 2005

SPC - September 30, 2005

SPC - September 30, 2005

SB -September 30, 2005

SB - September 30, 2005

SB - September 30, 2005

SB - Continuous

Met.

Under the foreign exchange law the BNB has requested leasing companies to report on their income statements and balance sheets on a quarterly basis with effect from September 30, 2005

The winning bidder for Varna EAD and Ruse EAD wa selected, although privatization has failed due to

unacceptable additional demands of the bidder and ruling of the competition agency against selling both plants to the same bidder. The tender for the Bobov Dol powe plant was canceled due to unsatisfactory offers.

Adopted on December 21, 2005. Lag due to delay in forming a new government and priority given to $\mathrm{EU}$ accession related legislation.

Accounts were incorporated into SEBRA on October 17, 2005. The delay was due to technical requirements.

Draft legislation was approved by the Council of Ministers on January 12, 2006 and submitted to parliament on January 28, 2006.

The new excise tax law was approved by parliament on November 2, 2005 and promulgated in the State Gazette on November 15, 2005 .

The property tax valuations have been raised by some 20 30 percent through amending the Law on Local Taxes and Charges, effective January 1, 2006

Since the first review no new public enterprices have been created.

\section{Current Status 2/}

Selection of winning bidders for the Varna and Ruse electricity generation companies is structural

performance criterion for June 30, 2006. A waive

is requested since the deal of the Bobov Dol powe plant was challenged and blocked in the courts. 
Table 2 (continued). Bulgaria: Observance of Structural Conditionality Under the Stand-By Arrangement in $20051 /$

Conditionality Not Met

1. Submit a constitutional amendment to parliament to allow municipalities to set their own tax rates.

2. Ministry of Finance to use only the Financial Management Information System.

3. Submission to parliament of a draft law raising the legal limits on maximum working hours, lengthening calculation periods, and expanding the reasons for work outside regular hours.

4. Issuance of a government decree eliminating the portability of the seniority premium in the case of unemployment.
Previous Status 2/

SB - June 30, 2005

SB - September 1, 2005

SB - September 30, 2005

SB - December 31, 2005

\section{Notes}

The government has proposed draft texts, however, a

constitutional amendment cannot be initiated by the

government but by 25 percent of all MPs and requires

75 percent parliamentary majority.

The two systems (the current one and the FMIS) are used in parallel.

The change in government has caused a slippage in

completing the measure on time. The new govent

has set up an intergovernmental working group involving

socil parners The first meting of the working goup

was on January 10, 2006.

Due to the change in government the measure has slipped beyond the envisaged completion date. The new

government has set up an intergovernmental working

group involving social partners which first meeting was on January 10, 2006
Current Status 2/

Agreement with social partners to that effect is structural benchmark for March 31, 2006 and submission to parliament of legislation increasing working time flexibility is structural benchmark for June 30, 2006

Agreement with social partners to eliminate the seniority bonuses is SB for March 31, 2006 and adoption of a decree eliminating the seniority bonuses is SB for June 30, 2006 . 
Table 3. Bulgaria: Quantitative Performance Criteria and Indicative Targets Under the Stand-By Arrangement 1/ (In millions of leva, unless otherwise indicated)

June 30

I. Floor on the overall fiscal surplus of the general

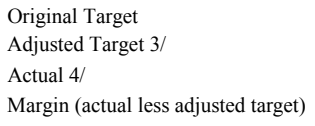

$\begin{array}{rr}699 & 2 / \\ \mathrm{n} / \mathrm{a} & \\ 810 & \\ 111 & \end{array}$

403
$\mathrm{n} / \mathrm{a}$
1,247
844

0
$\mathrm{n} / \mathrm{a}$
330
330

$\begin{array}{lr}198 & 383 \\ 277 & 556 \\ 486 & 1,081 \\ 209 & 525\end{array}$

605

614
1,378

914
1,378

464

II. Ceiling on central government arrears 4/
Target
Actual 5/
Margin

III Expenditure ceiling 4/

Target
Actual
Margin

IV Ceiling on the wage bill of the selected SOEs 4

Target 6

Actual

Margin

V. Ceiling on the contracting or guaranteeing of

nonconcessional external public debt 7/

(i) 1 year and less than 3 years

Target
Actual
Margin
(ii) Over 1 year
Target
Actual
Margin
(iii) $1-5$ years
Target
Actual
Margin

$\begin{array}{lllr}-9.8 & 2 / & -54.8 & -54.8 \\ -8.7 & & -44.2 & -52.6 \\ -1.1 & & -10.6 & -2.2\end{array}$

$\begin{array}{rrr}6,469 & 2 / & 10,2 \\ 6,407 & & 9,7 \\ 62 & 482 \\ & \\ 283.0 & 404.3 \\ 265.1 & 379.1 \\ 17.9 & 25.2\end{array}$

17.9

$$
\begin{array}{r}
14,275 \\
14,588 \\
-313 \\
\\
525.2 \\
489.0 \\
36.2
\end{array}
$$

$\begin{array}{rrr}0 & 0 & \\ 0 & 0 & \\ 0 & 0 & \\ & & \\ 150.0 & 390.0 & 390.0 \\ 0 & 309.7 & 309.7 \\ 150.0 & 80.3 & 80 .\end{array}$$$
-54.8
$$$$
-2.2
$$

$5.0 \quad 5.0$

$3.5 \quad 2.3$

$1.5 \quad 2.7$

417

943

Definitions of the performance criteria are included in the Annexes to the Memorandum of Economic and Financial Policies, August 2004 and the Supplementary Memorandum of Economic and Financial Policies, March 2005 .

2/ Indicative limit or target.

$3 /$ The targets will be raised by 69 percent of the cumulative tax revenue (excluding personal income tax) overperformance in 2005.

4/ The targets will be raised by 69 percent of the cumulative tax revenue (excluding personal income tax) overperformance in 2005 .

4/ Cumulative change from January 1, 2004 for 2004 pert

5/ Includes change in net central government arrears.
6/ Targets have changed compared to EBS/04/107 due to the privatization of BTC in Q2 2004 and Balkan Mine 2000, Open coal mine, and Brikel SOEs in Q3 2004, and of Mina Zdravec EAD and Eood Central Base-Pernik in Q4 2004. Targets for 2005 have changed compared to EBS/05/68 due to staff layoffs in Terem EAD in Q1 and closures of Balkancar Zaria, Elektrostomana, Dunarid AD, and Balkancar 6th September in Q2 2005 .

7/In millions of euro. Cumulative change from December 31, 2004 for 2004 performance criteria and December 31, 2005 for 2005 performance criteria. 
Table 4. Bulgaria: Selected Economic Indicators, 2001-06

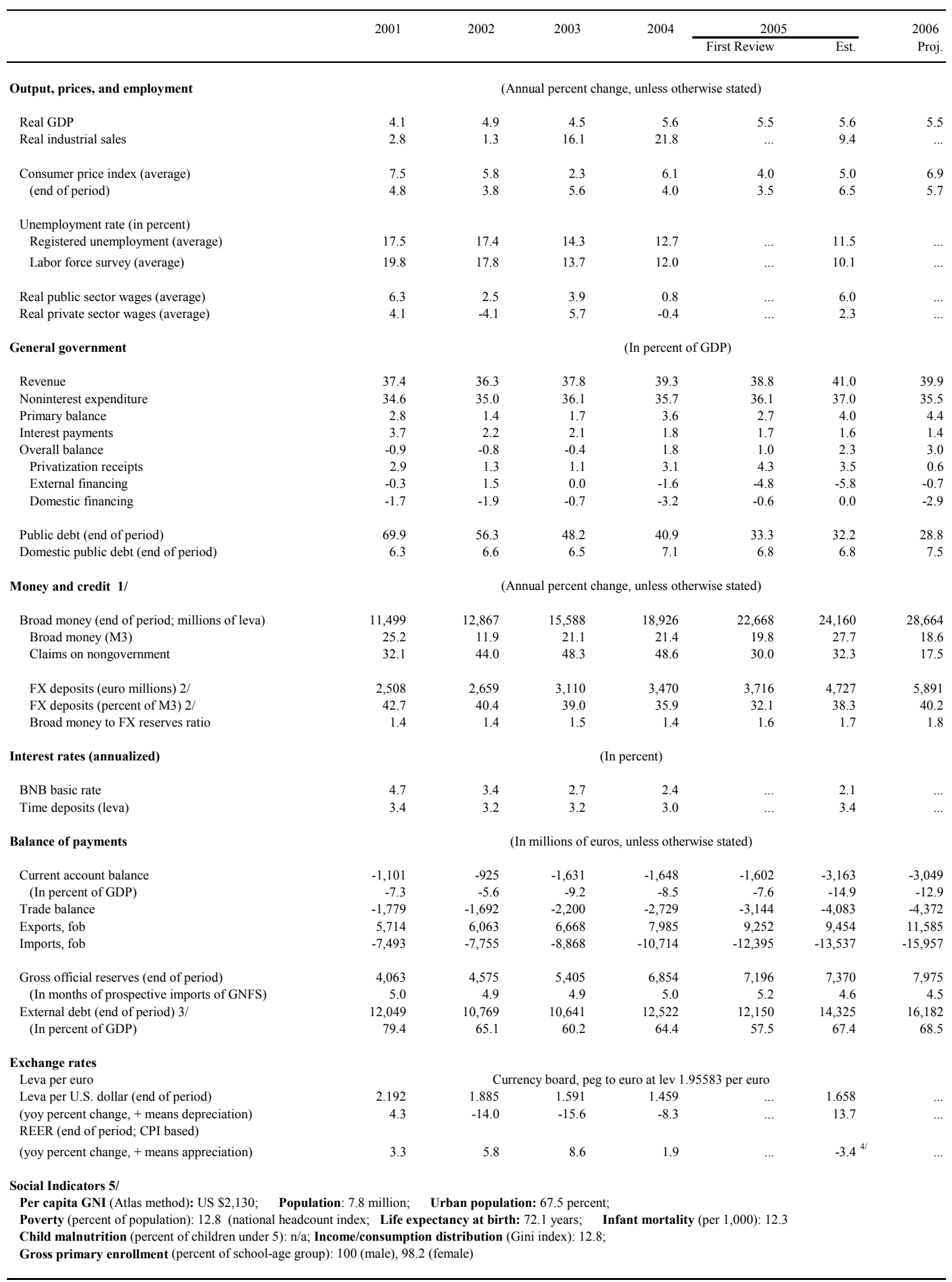

Sources: Bulgarian authorities, Fund staff estimates, and World Development Indicators database.

1/ Starting in 2002, a new format was adopted for monetary data resulting in revisions to historical series.

2/ Includes only foreign currency deposits in M3.

3 / Includes trade credits.

4 / November 2005 .

5/ 2001 figure for gross primary enrollment, income/consumption distribution, poverty rate. 2003 figure for per capita GNI, urban population,

life expectancy, infant mortality, and total population. 
Table 5. Bulgaria: Selected Vulnerability Indicators, 2002-06

\begin{tabular}{|c|c|c|c|c|c|c|}
\hline & 2002 & 2003 & 2004 & 2005 & 2006 & \\
\hline \multicolumn{7}{|l|}{ Key Economic and Market Indicators } \\
\hline Real GDP growth (in percent) & 4.9 & 4.5 & 5.6 & 5.6 & 5.5 & Proj. \\
\hline CPI inflation (period average, in percent) & 5.8 & 2.3 & 6.1 & 5.0 & 6.9 & Proj. \\
\hline Short-term (ST) interest rate (in percent) & 3.4 & 2.7 & 2.4 & 2.1 & $\ldots$ & Dec-05 \\
\hline EMBI + secondary market spread (bps; end of period) & 291 & 177 & 77 & 90 & 69 & 1-Mar-06 \\
\hline Exchange rate NC/US\$ (end of period) & 1.9 & 1.6 & 1.4 & 1.7 & 1.6 & Jan-06 \\
\hline \multicolumn{7}{|l|}{ External Sector } \\
\hline Exchange rate regime & \multicolumn{6}{|c|}{ Currency board, peg to euro at lev 1.95583 per euro } \\
\hline Current account balance (percent of GDP) & -5.6 & -9.2 & -8.5 & -14.9 & -12.9 & Proj. \\
\hline Net FDI inflows (percent of GDP) & 5.8 & 10.3 & 5.7 & 10.8 & 9.4 & Proj. \\
\hline Export growth (yoy, Euro value, GNFS) & 5.5 & 10.7 & 20.0 & 15.7 & 20.9 & Proj. \\
\hline Real effective exchange rate $(1995=100$; end of period $))$ & 139.9 & 151.9 & 154.9 & 150.3 & $\ldots$ & Nov- 05 \\
\hline Gross international reserves (GIR) in Euro billion & 4.6 & 5.4 & 6.9 & 7.4 & 8.0 & Proj. \\
\hline GIR in percent of ST debt at remaining maturity & 212.5 & 177.1 & 111.4 & 155.7 & 137.8 & Proj. \\
\hline GIR in percent of ST debt at RM and banks' FX deposits. & 93.8 & 77.7 & 62.1 & 71.3 & 62.4 & Proj. \\
\hline Net international reserves (NIR) in Euro billion & 3.6 & 4.5 & 6.0 & 6.8 & 7.7 & Proj. \\
\hline Total gross external debt in percent of GDP 3 / & 65.1 & 60.2 & 64.4 & 67.4 & 68.5 & Proj. \\
\hline $\mathrm{o} / \mathrm{w}$ ST external debt (original maturity, in percent of total ED) & 14.1 & 14.3 & 19.8 & 25.6 & 28.8 & Proj. \\
\hline ED of domestic private sector (in percent of total ED) & 26.1 & 33.8 & 48.7 & 64.1 & 67.5 & Proj. \\
\hline ED to foreign official sector (in percent of total ED) & 30.4 & 29.3 & 26.5 & 22.6 & 19.8 & Proj. \\
\hline Total gross external debt in percent of exports of GNFS & 126.1 & 112.5 & 110.4 & 109.8 & 102.4 & Proj. \\
\hline Gross external financing requirement (in Euro billion) 2/ & 1.9 & 2.6 & 3.7 & 8.2 & 4.1 & Proj. \\
\hline \multicolumn{7}{|l|}{ Public Sector 3/ } \\
\hline Overall balance (percent of GDP) & -0.8 & -0.4 & 1.8 & 2.3 & 3.0 & Proj. \\
\hline Primary balance (percent of GDP) & 1.4 & 1.7 & 3.6 & 4.0 & 4.4 & Proj. \\
\hline Debt-stabilizing primary balance (percent of GDP) 4 / & $\ldots$ & $\ldots$ & $\ldots$ & $\ldots$ & 1.0 & Proj. \\
\hline Gross public sector financing requirement (in percent of GDP) 5 / & 10.6 & 6.1 & 4.2 & 8.1 & 2.5 & Proj. \\
\hline Public sector gross debt (in percent of GDP) 6/ & 56.3 & 48.2 & 40.9 & 32.2 & 28.8 & Proj. \\
\hline o/w Exposed to rollover risk (in percent of total PSGD) 6/ & 8.4 & 8.0 & 12.9 & 30.5 & 13.3 & Proj. \\
\hline Exposed to exchange rate risk (in percent of total PSGD) 7/ & 91.7 & 91.0 & 88.2 & 85.3 & 80.2 & Proj. \\
\hline Exposed to interest rate risk (in percent of total PSGD) 8/ & 59.0 & 56.7 & 51.7 & 39.5 & 32.6 & Proj. \\
\hline $\mathrm{o} / \mathrm{w}$ External debt from official creditors (in percent of total) & 29.7 & 31.3 & 34.1 & 36.0 & 29.3 & Proj. \\
\hline External debt from private creditors (in percent of total) & 25.8 & 22.2 & 14.6 & 0.0 & 0.0 & Proj. \\
\hline Domestic debt linked to foreign currency (in percent of total) & 3.4 & 3.1 & 3.0 & 3.4 & 3.2 & Proj. \\
\hline Public sector net debt (in percent of GDP) $9 /$ & 45.5 & 36.6 & 27.5 & 21.4 & $\ldots$ & Dec-05 \\
\hline \multicolumn{7}{|l|}{ Financial Sector 10/ } \\
\hline Capital adequacy ratio (in percent) & 25.2 & 22.0 & 16.1 & 15.2 & $\ldots$ & Dec-05 \\
\hline Non-standard loans in percent of total loans 11/ & 8.6 & 7.3 & 6.9 & 7.7 & $\ldots$ & Dec-05 \\
\hline Return on average assets (in percent) & 2.1 & 2.4 & 2.1 & 2.1 & $\ldots$ & Dec-05 \\
\hline Return on equity (in percent) & 14.9 & 22.7 & 20.6 & 22.1 & $\ldots$ & Dec-05 \\
\hline FX deposits (in percent of total deposits) & 54.3 & 52.1 & 48.0 & 47.2 & $\ldots$ & Dec-05 \\
\hline FX loans (in percent of total loans) & 55.8 & 52.6 & 53.7 & 50.3 & $\ldots$ & Dec-05 \\
\hline Net open forex position (in percent of capital) 12/ & -4.2 & -4.9 & -5.9 & -5.6 & $\ldots$ & Jun-05 \\
\hline Government debt held by FS ( percent of total FS assets) & 23.8 & 19.8 & 16.5 & 14.4 & $\ldots$ & Nov-05 \\
\hline Credit to private sector (percent change) & 44.0 & 48.3 & 48.6 & 32.4 & $\cdots$ & Dec-05 \\
\hline \multicolumn{7}{|l|}{ Memo item: } \\
\hline Nominal GDP in billions of euros & 16.5 & 17.7 & 19.4 & 21.3 & 23.6 & Proj. \\
\hline Nominal GDP in billions of U.S. dollars & 15.7 & 20.0 & 24.2 & 26.4 & 28.0 & Proj. \\
\hline
\end{tabular}

Sources: Bulgarian authorities; and Fund staff estimates.

1/ For 2005, staff estimates or latest available observations as indicated in the last column. For 2006, staff projection.

$2 /$ Current account deficit plus amortization of external debt.

3/ Public sector covers central government, autonomous budgets, social security funds, municipal budgets, and extra budgetary funds.

4/ Based on averages for the last five years for the relevant variables (i.e., growth, interest rates).

5/ Overall balance plus debt amortization.

6/ Amorization on domestic and external debt (excluding external debt to official creditors) in 2005 divided by 2004 total debt stock.

$7 /$ Debt in foreign currency or linked to the exchange rate, domestic and external. Does not exclude external debt on concessional terms.

8 / Total debt at variable interest rate (domestic and external).

9/ Public sector gross debt minus balance of the fiscal reserve account.

10/ Financial sector covers banking sector only excluding insurance, pension funds and capital market institutions.

11/ Loans overdue by more than 30 days.

12 / Sum of on- and off-balance sheet exposure. 
Table 6. Bulgaria: Real GDP by expenditure category, 2001-06

\begin{tabular}{|c|c|c|c|c|c|c|c|}
\hline & \multirow[t]{2}{*}{2001} & \multirow[t]{2}{*}{2002} & \multirow[t]{2}{*}{2003} & \multirow[t]{2}{*}{2004} & \multicolumn{2}{|c|}{2005} & \multirow{2}{*}{$\begin{array}{l}2006 \\
\text { proj. }\end{array}$} \\
\hline & & & & & First Rev. & Est. & \\
\hline & \multicolumn{7}{|c|}{ (Percentage change) } \\
\hline Real GDP & 4.1 & 4.9 & 4.5 & 5.6 & 5.5 & 5.6 & 5.5 \\
\hline Domestic demand 1/ & 7.1 & 3.8 & 8.9 & 7.1 & 5.7 & 10.2 & 4.6 \\
\hline Private demand & 8.6 & 4.6 & 8.9 & 7.4 & 5.8 & 10.4 & 5.2 \\
\hline Public demand & 1.5 & 0.8 & 8.7 & 6.0 & 6.0 & 9.3 & 2.2 \\
\hline Final consumption & 4.4 & 3.6 & 6.6 & 5.0 & 4.2 & 6.6 & 3.3 \\
\hline Private consumption & 5.2 & 3.5 & 6.4 & 5.4 & 4.6 & 7.1 & 4.0 \\
\hline Public consumption & 1.4 & 4.1 & 7.5 & 3.6 & 2.8 & 4.9 & 1.0 \\
\hline Gross Investment & 20.1 & 4.4 & 18.2 & 14.8 & 10.2 & 22.3 & 8.3 \\
\hline Gross fixed capital formation & 23.3 & 8.5 & 13.9 & 12.0 & 13.0 & 19.0 & 9.7 \\
\hline Changes in inventories & 0.4 & -25.8 & 69.2 & 37.8 & -12.8 & 42.9 & 0.0 \\
\hline Net exports & 64.6 & -10.6 & 74.0 & 19.8 & 5.5 & -38.3 & 1.0 \\
\hline Exports of goods and services & 10.0 & 7.0 & 8.0 & 13.1 & 12.2 & 4.9 & 12.7 \\
\hline \multirow[t]{2}{*}{ Imports of goods and services } & 14.8 & 4.9 & 15.3 & 14.1 & 11.2 & 12.2 & 9.7 \\
\hline & \multicolumn{7}{|c|}{ (Contribution to real GDP growth) 2/ } \\
\hline Domestic demand & 7.5 & 4.1 & 9.3 & 7.6 & 6.1 & 11.0 & 5.3 \\
\hline Private demand & 7.2 & 3.9 & 7.5 & 6.4 & 5.0 & 8.8 & 4.8 \\
\hline Public demand & 0.3 & 0.2 & 1.8 & 1.3 & 1.1 & 2.0 & 0.5 \\
\hline Final consumption & 3.8 & 3.2 & 5.7 & 4.4 & 3.7 & 5.7 & 2.9 \\
\hline Private consumption & 3.6 & 2.5 & 4.4 & 3.7 & 3.2 & 4.8 & 2.8 \\
\hline Public consumption & 0.2 & 0.7 & 1.4 & 0.7 & 0.5 & 0.9 & 0.2 \\
\hline Gross capital formation & 3.7 & 0.9 & 3.6 & 3.2 & 2.4 & 5.2 & 2.3 \\
\hline Gross fixed capital formation & 3.7 & 1.5 & 2.5 & 2.3 & 2.7 & 4.0 & 2.3 \\
\hline Changes in inventories & 0.0 & -0.6 & 1.1 & 0.9 & -0.3 & 1.1 & 0.0 \\
\hline Net exports & -3.5 & 0.8 & -4.9 & -1.9 & -0.6 & -5.5 & 0.2 \\
\hline Exports of goods and services & 5.6 & 3.9 & 4.3 & 7.0 & 7.1 & 2.9 & 7.8 \\
\hline \multirow[t]{2}{*}{ Imports of goods and services } & -9.0 & -3.1 & -9.1 & -8.9 & -7.7 & -8.4 & -7.6 \\
\hline & \multicolumn{7}{|c|}{ (Percentage change in implicit deflators) } \\
\hline GDP & 6.7 & 3.8 & 2.3 & 4.2 & 3.0 & 3.6 & 5.4 \\
\hline Final consumption & 6.2 & 4.9 & 1.3 & 3.7 & 2.7 & 5.0 & 5.1 \\
\hline Gross capital formation & 4.5 & -0.1 & -0.8 & 3.6 & 4.8 & 6.3 & 5.1 \\
\hline \multicolumn{8}{|l|}{ Net exports } \\
\hline Exports of goods and services & 0.7 & -2.8 & -0.3 & 6.2 & 3.3 & 9.4 & 7.6 \\
\hline Imports of goods and services & 0.1 & -1.8 & -2.2 & 5.1 & 3.5 & 10.9 & 6.6 \\
\hline \multicolumn{8}{|l|}{ Memorandum items } \\
\hline Share of domestic demand in nominal GDP & 107.6 & 106.6 & 109.5 & 110.3 & 110.5 & 116.8 & 115.4 \\
\hline Share of domestic private demand in nominal GDP & 86.1 & 85.3 & 87.1 & 87.7 & 96.3 & 92.8 & 94.7 \\
\hline Share of domestic public demand in nominal GDP & 21.5 & 21.3 & 22.4 & 22.6 & 14.2 & 24.0 & 23.5 \\
\hline Share of net exports in nominal GDP & -7.6 & -6.6 & -9.5 & -10.3 & -10.4 & -16.8 & -15.3 \\
\hline Nominal GDP (in millions of leva) & 29,709 & 32,335 & 34,547 & 38,009 & 41,302 & 41,570 & 46,221 \\
\hline
\end{tabular}

Sources: National Statistical Institute for actuals; Agency for Economic Forecasting and Analysis, Bulgarian National Bank, and staff estimates.

1/ Private and public sector decomposition based on staff calculations and not officially reported by the NSI.

2/ Sum of contributions to real GDP growth may not add up to total growth due to statistical discrepancy in the official data. 
Table 7. Bulgaria: Balance of Payments, 2004-06 (In millions of euros)

\begin{tabular}{|c|c|c|c|c|c|c|c|c|c|c|c|c|}
\hline & \multirow{2}{*}{2004} & \multicolumn{6}{|c|}{2005} & \multicolumn{5}{|c|}{2006 Proj. } \\
\hline & & $\begin{array}{r}\text { First Review } \\
\text { Projection }\end{array}$ & Q1 & Q2 & Q3 & Q4 & Year & Q1 & Q2 & Q3 & Q4 & Year \\
\hline CURRENT ACCOUNT & $-1,648$ & $-1,602$ & -687 & -727 & -427 & $-1,323$ & $-3,163$ & -832 & -755 & -206 & $-1,257$ & $-3,049$ \\
\hline Trade balance & $-2,729$ & $-3,144$ & -651 & $-1,040$ & $-1,100$ & $-1,291$ & $-4,083$ & -768 & $-1,198$ & $-1,223$ & $-1,183$ & $-4,372$ \\
\hline Exports (f.o.b.) & 7,985 & 9,252 & 2,081 & 2,305 & 2,415 & 2,654 & 9,454 & 2,656 & 2,831 & 2,957 & 3,142 & 11,585 \\
\hline $\mathrm{y}-\mathrm{o}-\mathrm{y}$ change (in percent) & 19.7 & 15.7 & 21.1 & 21.5 & 10.6 & 21.4 & 18.4 & 27.6 & 22.8 & 22.5 & 18.4 & 22.5 \\
\hline Imports (f.o.b.) & $-10,714$ & $-12,395$ & $-2,732$ & $-3,346$ & $-3,515$ & $-3,945$ & $-13,537$ & $-3,423$ & $-4,029$ & $-4,180$ & $-4,325$ & $-15,957$ \\
\hline $\mathrm{y}-\mathrm{o}-\mathrm{y}$ change (in percent) & 20.8 & 15.7 & 22.7 & 24.2 & 32.6 & 25.5 & 26.3 & 25.3 & 20.4 & 18.9 & 9.6 & 17.9 \\
\hline Services, net & 723 & 939 & -69 & 164 & 604 & -168 & 532 & -48 & 212 & 760 & -146 & 777 \\
\hline Of which: Exports of travel services & 1,746 & 2,004 & 216 & 490 & 956 & 227 & 1,888 & 255 & 556 & 1,096 & 291 & 2,199 \\
\hline Income, net $1 /$ & -531 & -408 & -139 & -90 & -170 & -152 & -551 & -233 & -120 & -145 & -62 & -561 \\
\hline Of which: Income to direct investors & -456 & -339 & -65 & -109 & -166 & -182 & -522 & -127 & -127 & -127 & -127 & -507 \\
\hline Current transfers, net & 888 & 1,011 & 172 & 239 & 239 & 288 & 938 & 217 & 351 & 402 & 135 & 1,106 \\
\hline CAPITAL AND FINANCIAL ACCOUNT & 3,186 & 2,233 & 573 & 1,429 & 282 & 1,563 & 3,847 & 855 & 939 & 667 & 1,477 & 3,938 \\
\hline Capital transfers, net & 0 & 0 & 0 & -1 & 0 & 0 & -1 & 0 & 0 & 0 & 0 & 0 \\
\hline Foreign direct investment, net $2 / 3 /$ & 1,104 & 2,132 & 908 & 322 & 740 & 327 & 2,297 & 520 & 520 & 520 & 670 & 2,229 \\
\hline Of which: Privatization receipts 4/ & 243 & 916 & 554 & 0 & 139 & 0 & 693 & 0 & 0 & 0 & 150 & 150 \\
\hline Portfolio investment, net & -557 & $-1,247$ & -725 & 267 & -378 & 80 & -757 & 11 & 11 & 11 & 11 & 46 \\
\hline Other investment, net & 2,220 & 1,349 & 848 & 130 & -263 & 558 & 1,274 & 324 & 408 & 136 & 796 & 1,664 \\
\hline General government & 102 & 141 & -28 & 23 & -71 & 131 & 55 & -133 & 81 & 94 & 8 & 49 \\
\hline Domestic banks & 1,036 & 253 & 128 & -320 & -162 & 176 & -177 & -41 & -361 & 116 & -500 & -786 \\
\hline Other private sector & 1,081 & 955 & 748 & 426 & -29 & 251 & 1,396 & 498 & 688 & -74 & 1,288 & 2,400 \\
\hline Errors and omissions & 419 & 0 & -459 & 712 & 183 & 598 & 1,034 & 0 & 0 & 0 & 0 & 0 \\
\hline OVERALL BALANCE & 1,538 & 632 & -114 & 702 & -145 & 240 & 684 & 23 & 185 & 460 & 220 & 889 \\
\hline FINANCING & $-1,538$ & -632 & 114 & -702 & 145 & -240 & -684 & -23 & -185 & -460 & -220 & -889 \\
\hline Gross international reserves (increase: -) & $-1,493$ & -425 & 147 & -650 & 196 & -17 & -324 & 171 & -150 & -429 & -197 & -605 \\
\hline Use of Fund credit, net & -44 & -206 & -32 & -52 & -52 & -223 & -359 & -195 & -35 & -31 & -24 & -284 \\
\hline Purchases & 62 & 0 & 0 & 0 & 0 & 0 & 0 & 0 & 0 & 0 & 0 & 0 \\
\hline Repurchases 5/ & -106 & -206 & -32 & -52 & -52 & -223 & -359 & -195 & -35 & -31 & -24 & -284 \\
\hline Exceptional financing & 0 & 0 & 0 & 0 & 0 & 0 & 0 & 0 & 0 & 0 & 0 & 0 \\
\hline \multicolumn{13}{|l|}{ MEMORANDUM ITEMS } \\
\hline Gross international reserves (stock, e.o.p.) 6/ & 6,854 & 7,196 & 6,748 & 7,453 & 7,299 & 7,370 & 7,370 & 7,199 & 7,349 & 7,778 & 7,975 & 7,975 \\
\hline In months of prospective GNFS imports & 5.0 & 5.2 & 4.7 & 4.9 & 4.6 & 4.6 & 4.6 & 4.0 & 4.1 & 4.3 & 4.5 & 4.5 \\
\hline In percent of short-term debt (original maturity) & 276.7 & 182.9 & 183.7 & 202.9 & 198.7 & 200.6 & 200.6 & 149.8 & 153.0 & 162.3 & 167.2 & 166.8 \\
\hline Excess international reserves (stock, e.o.p.) $7 /$ & 3,245 & $\ldots$ & 3,342 & 3,728 & 3,292 & 3,100 & 3,100 & 2,875 & 2,896 & 3,192 & 3,144 & 3,124 \\
\hline In percent of short-term debt & 131.0 & $\ldots$ & 99.2 & 117.8 & 103.7 & 84.4 & 84.4 & 77.0 & 73.9 & 76.6 & 67.5 & 67.0 \\
\hline Current account + FDI & -544 & 530 & 221 & -405 & 313 & -995 & -866 & -312 & -235 & 313 & -587 & -820 \\
\hline (in percent of GDP) & -2.8 & 2.5 & 1.0 & -1.9 & 1.5 & -4.7 & -4.1 & -6.4 & -4.3 & 4.7 & -8.8 & -3.5 \\
\hline Current account (in percent of GDP) & -8.5 & -7.6 & -15.5 & -14.6 & -7.2 & -22.4 & -14.9 & -17.0 & -13.8 & -3.1 & -18.9 & -12.9 \\
\hline Merchandise trade account (in percent of GDP) & -14.0 & -14.9 & -14.7 & -20.9 & -18.5 & -21.9 & -19.2 & -15.7 & -21.9 & -18.5 & -17.8 & -18.5 \\
\hline Merchandise exports (in percent of GDP) & 41.1 & 43.8 & 46.8 & 46.3 & 40.6 & 45.0 & 44.5 & 54.4 & 51.7 & 44.7 & 47.2 & 49.0 \\
\hline Merchandise imports (in percent of GDP) & -55.1 & -58.7 & -61.5 & -67.2 & -59.2 & -67.0 & -63.7 & -70.1 & -73.6 & -63.1 & -65.0 & -67.5 \\
\hline Export volume (year-on-year change) & 8.8 & 12.8 & 9.0 & 11.5 & -3.3 & 0.7 & 4.1 & 10.5 & 10.9 & 16.3 & 16.0 & 13.3 \\
\hline Import volume (year-on-year change) & 12.8 & 11.5 & 11.1 & 14.5 & 15.1 & 3.5 & 10.9 & 7.8 & 9.1 & 14.2 & 7.8 & 9.4 \\
\hline FDI (net) in percent of current account & 67.0 & 133.1 & 132.2 & 44.3 & 173.3 & 24.8 & 72.6 & $\ldots$ & $\ldots$ & $\ldots$ & $\ldots$ & 73.1 \\
\hline Gross external debt (stock, e.o.p.) 8/ & 12,522 & 12,150 & 13,114 & 13,578 & 13,521 & 14,325 & 14,325 & 14,270 & 14,762 & 15,157 & 16,182 & 16,182 \\
\hline (In percent of annual GDP) & 64.4 & 57.5 & 61.7 & 63.9 & 63.6 & 67.4 & 67.4 & 60.4 & 62.5 & 64.1 & 68.5 & 68.5 \\
\hline Public & 6,429 & 5,374 & 5,779 & 5,889 & 5,299 & 5,139 & 5,139 & 4,949 & 5,075 & 5,205 & 5,253 & 5,253 \\
\hline Private & 6,093 & 6,776 & 7,336 & 7,689 & 8,222 & 9,186 & 9,186 & 9,321 & 9,687 & 9,951 & 10,929 & 10,929 \\
\hline Short-term debt (in percent of total debt, e.o.p.) & 19.8 & 32.4 & 25.7 & 23.3 & 23.5 & 25.6 & 25.6 & 26.2 & 26.6 & 27.5 & 28.8 & 28.8 \\
\hline Net external debt (in percent of annual GDP) $9 /$ & 17.4 & 13.3 & 19.2 & 18.0 & 19.1 & 21.5 & 21.5 & 20.5 & 21.3 & 19.7 & 22.0 & 22.0 \\
\hline GDP & 19,433 & 21,117 & 4,443 & 4,979 & 5,941 & 5,892 & 21,254 & 4,881 & 5,474 & 6,620 & 6,657 & 23,632 \\
\hline
\end{tabular}

1/ Revisions to the 2004 data since the May 2004 Board meeting have led to a deterioration of about 0.8 percent of GDP.

2/ All FDI are assumed to be non-debt creating in the projections.

$3 /$ The figures for 2004 and 2005 are influenced by a complex debt financed merger and acquisition transaction of a local mobile telephone

company that led to a sharp increase in its equity value, and a transfer of the realized capital gains out of the country by the original owners. This resulted in a net

FDI outflow of 650 million euros and an increase in gross external debt by 590 million euros in 2004.

4/ Privatization receipts for the electricity distribution companies are included in 2005. These are included in the receipts for 2004 in the balance of payments presentation of the BNB. The present treatment aligns them with its receipt in the fiscal accounts.

5/ According to expectations schedule.

6/ Historical numbers include valuation changes. From 2006-10 includes reserves posted as a guarantee for defense related purchases. Reserve coverage ratios are calculated net

of impaired reserves.

7/ Gross international reserves minus reserve money. For 2006-08, reserves posted as a guarantee for defense related purchases are excluded.

8/ Projections include assumptions on disbursements related to debt not already contracted.

9/ External debt minus gross foreign assets of the banking system. 
Table 8. Bulgaria: Balance of Payments, 2004-2006: Analysis of Developments

\begin{tabular}{|c|c|c|c|c|c|}
\hline & \multirow{2}{*}{$\begin{array}{r}2004 \\
\text { Actual }\end{array}$} & \multicolumn{3}{|c|}{2005} & \multirow{2}{*}{$\begin{array}{r}2006 \\
\text { Projection }\end{array}$} \\
\hline & & First review & Estimate & $\overline{\text { Difference }}$ & \\
\hline & \multicolumn{4}{|c|}{ (In percent of GDP) } & \\
\hline Current Account & -8.5 & -7.6 & -14.9 & -7.3 & -12.9 \\
\hline Trade Balance & -14.0 & -14.9 & -19.2 & -4.3 & -18.5 \\
\hline Exports & 41.1 & 43.8 & 44.5 & 0.7 & 49.0 \\
\hline Consumer goods & 13.5 & 14.0 & 12.8 & -1.2 & 12.6 \\
\hline of which: Textiles & 8.0 & 7.6 & 7.2 & -0.4 & 6.9 \\
\hline Investment goods & 5.5 & 5.9 & 6.8 & 0.9 & 7.3 \\
\hline Raw Materials & 17.9 & 19.1 & 19.1 & 0.0 & 23.0 \\
\hline of which: Iron \& Steel & 4.1 & 4.4 & 3.6 & -0.8 & 4.3 \\
\hline Other metals (mainly copper) & 3.9 & 4.0 & 4.4 & 0.4 & 4.2 \\
\hline Fuel & 4.2 & 4.8 & 5.7 & 1.0 & 6.1 \\
\hline Imports & -55.1 & -58.7 & -63.7 & -5.0 & -67.5 \\
\hline Consumer goods & -9.0 & -10.1 & -9.8 & 0.3 & -9.9 \\
\hline Investment Goods & -14.7 & -15.8 & -17.6 & -1.7 & -18.4 \\
\hline Raw Materials & -23.7 & -22.2 & -22.9 & -0.8 & -24.3 \\
\hline Fuel & -10.0 & -10.1 & -12.9 & -2.7 & -14.4 \\
\hline Services & 3.7 & 4.4 & 2.5 & -1.9 & 3.3 \\
\hline Travel (exports) & 9.0 & 9.5 & 8.9 & -0.6 & 9.3 \\
\hline Other Services, net & 0.1 & 0.5 & -0.7 & -1.2 & -0.5 \\
\hline Income, net & -2.7 & -1.9 & -2.6 & -0.7 & -2.4 \\
\hline Transfers, net & 4.6 & 4.8 & 4.4 & -0.4 & 4.7 \\
\hline Private transfers & 4.2 & 4.4 & 3.7 & -0.7 & 4.1 \\
\hline \multicolumn{6}{|l|}{ Memorandum items: } \\
\hline Fuel, net & -5.8 & -5.3 & -7.1 & -1.8 & -8.3 \\
\hline \multicolumn{6}{|l|}{ of which: } \\
\hline Privatization proceeds & 1.3 & 4.3 & 3.3 & -1.1 & 0.6 \\
\hline \multirow[t]{2}{*}{ Mobiltel related } & -2.3 & 0.0 & -0.1 & -0.1 & 0.0 \\
\hline & \multicolumn{4}{|c|}{ (Annual percentage change) } & \\
\hline Export volume (goods) & 8.8 & 12.8 & 4.1 & -8.7 & 13.3 \\
\hline Import volume (goods) & 12.8 & 11.5 & 10.9 & -0.6 & 9.4 \\
\hline Export deflator (goods) & 10.0 & 2.6 & 13.7 & 11.1 & 8.1 \\
\hline Import deflator (goods) & 7.1 & 3.8 & 13.9 & 10.1 & 7.7 \\
\hline GDP (in billions of euros) & 19.4 & 21.1 & 21.3 & 0.1 & 23.6 \\
\hline
\end{tabular}

Sources: Bulgarian authorities; and Fund staff estimates. 
Table 9: Bulgaria, Monetary Survey, 2004-06 (End-period; in millions of leva, unless otherwise stated)

\begin{tabular}{|c|c|c|c|c|c|c|c|c|c|c|}
\hline & \multirow{2}{*}{$\begin{array}{r}2004 \\
\text { Act. }\end{array}$} & \multicolumn{5}{|c|}{2005} & \multicolumn{4}{|c|}{2006} \\
\hline & & $\begin{array}{l}\text { Q1 } \\
\text { Act. }\end{array}$ & $\begin{array}{l}\text { Q2 } \\
\text { Act. }\end{array}$ & $\begin{array}{r}\text { Q3 } \\
\text { Act. }\end{array}$ & $\begin{array}{c}\mathrm{Q} 4 \\
\text { First Review }\end{array}$ & $\begin{array}{r}\text { Q4 } \\
\text { Proj. }\end{array}$ & $\begin{array}{r}\text { Q1 } \\
\text { Proj. }\end{array}$ & $\begin{array}{l}\text { Q2 } \\
\text { Proj. }\end{array}$ & $\begin{array}{r}\text { Q3 } \\
\text { Proj. }\end{array}$ & $\begin{array}{r}\text { Q4 } \\
\text { Proj. }\end{array}$ \\
\hline Broad money & 18,926 & 21,887 & 21,476 & 22,483 & 22,668 & 24,160 & 24,595 & 25,708 & 26,653 & 28,664 \\
\hline Currency outside banks & 4,628 & 4,487 & 4,848 & 5,213 & 5,364 & 5,396 & 5,112 & 5,424 & 5,793 & 5,964 \\
\hline Reserve money & 7,058 & 6,662 & 7,286 & 7,837 & 8,179 & 8,351 & 8,034 & 8,264 & 8,505 & 9,097 \\
\hline Deposits & 14,298 & 17,399 & 16,628 & 17,271 & 17,305 & 18,764 & 19,483 & 20,284 & 20,859 & 22,700 \\
\hline Lev & 7,512 & 8,904 & 8,578 & 9,146 & 10,037 & 10,052 & 10,131 & 10,548 & 10,847 & 11,804 \\
\hline Foreign currency & 6,786 & 8,495 & 8,051 & 8,124 & 7,268 & 8,712 & 9,352 & 9,736 & 10,013 & 10,896 \\
\hline Other longer-term liabilities (not incl. in broad money) & 4,767 & 5,256 & 5,517 & 5,877 & 5,931 & 6,216 & 6,384 & 6,558 & 6,737 & 6,923 \\
\hline Deposits & 571 & 683 & 723 & 747 & 906 & 827 & 876 & 929 & 985 & 1,044 \\
\hline Lev & 225 & 296 & 262 & 277 & 363 & 294 & 351 & 372 & 394 & 418 \\
\hline Foreign currency & 346 & 387 & 461 & 470 & 544 & 533 & 526 & 557 & 591 & 626 \\
\hline Capital and reserves & 4,196 & 4,573 & 4,794 & 5,130 & 5,025 & 5,389 & 5,508 & 5,629 & 5,753 & 5,879 \\
\hline Net foreign assets & 11,181 & 10,835 & 13,038 & 12,934 & 11,800 & 13,221 & 13,291 & 14,358 & 15,032 & 16,441 \\
\hline BNB & 11,571 & 11,547 & 12,974 & 12,775 & 12,750 & 13,343 & 13,369 & 13,729 & 14,630 & 15,062 \\
\hline Commercial banks & -390 & -712 & 64 & 159 & -950 & -122 & -78 & 628 & 402 & 1,379 \\
\hline Net domestic assets & 12,512 & 16,308 & 13,955 & 15,426 & 16,799 & 17,155 & 17,688 & 17,908 & 18,358 & 19,146 \\
\hline Domestic credit & 12,302 & 16,360 & 14,021 & 15,585 & 16,468 & 17,200 & 17,726 & 17,939 & 18,380 & 19,160 \\
\hline General government & $-1,808$ & $-1,625$ & $-2,246$ & $-1,623$ & $-1,881$ & $-1,462$ & $-1,329$ & $-1,902$ & $-2,308$ & $-2,768$ \\
\hline Non-government & 14,110 & 17,985 & 16,267 & 17,208 & 18,349 & 18,663 & 19,055 & 19,841 & 20,688 & 21,929 \\
\hline Claims on non-financial corporations & 9,306 & 12,242 & 10,319 & 10,654 & $\ldots$ & 11,439 & $\ldots$ & $\ldots$ & $\ldots$ & 1 \\
\hline Claims on households & 4,374 & 5,096 & 5,686 & 6,224 & $\ldots$ & 6,928 & $\ldots$ & $\ldots$ & $\ldots$ & $\ldots$ \\
\hline Other items, net & $-1,127$ & $-1,427$ & $-1,481$ & $-1,637$ & $-1,174$ & $-1,620$ & $-1,636$ & $-1,652$ & $-1,669$ & $-1,686$ \\
\hline \multirow[t]{2}{*}{ Fixed assets } & 1,337 & 1,375 & 1,415 & 1,477 & 1,505 & 1,575 & 1,598 & 1,622 & 1,647 & 1,671 \\
\hline & \multicolumn{10}{|c|}{ (12-month percentage change) } \\
\hline Broad money & 22 & 40 & 26 & 28 & 20 & 28 & 12 & 20 & 19 & 19 \\
\hline Currency outside banks & 19 & 21 & 22 & 20 & 16 & 17 & 14 & 12 & 11 & 11 \\
\hline Reserve money & 34 & 34 & 39 & 30 & 16 & 18 & 21 & 13 & 9 & 9 \\
\hline Claims on non-government & 49 & 73 & 42 & 36 & 30 & 32 & 6 & 22 & 20 & 18 \\
\hline Claims on non-financial corporations & 38 & 68 & 32 & 26 & $\ldots$ & 23 & & $\ldots$ & $\ldots$ & $\ldots$ \\
\hline Claims on households & 75 & 82 & 72 & 63 & $\ldots$ & 58 & $\ldots$ & $\ldots$ & $\ldots$ & $\ldots$ \\
\hline Deposits & 22 & 46 & 27 & 30 & 21 & 31 & 12 & 22 & 21 & 21 \\
\hline Lev & 34 & 60 & 47 & 41 & 34 & 34 & 14 & 23 & 19 & 17 \\
\hline \multirow[t]{2}{*}{ Foreign currency } & 12 & 33 & 12 & 20 & 7 & 28 & 10 & 21 & 23 & 25 \\
\hline & \multicolumn{10}{|c|}{ (quarterly growth rates) } \\
\hline Claims on non-government & 11.5 & 27.5 & -9.6 & 5.8 & 6.1 & 8.5 & 2.1 & 4.1 & 4.3 & 6.0 \\
\hline Claims on non-financial corporations & 9.8 & 31.5 & -15.7 & 3.2 & $\ldots$ & 7.4 & $\ldots$ & $\ldots$ & $\ldots$ & $\ldots$ \\
\hline \multirow[t]{2}{*}{ Claims on households } & 14.9 & 16.5 & 11.6 & 9.5 & $\ldots$ & 11.3 & $\ldots$ & $\ldots$ & $\ldots$ & $\ldots$ \\
\hline & \multicolumn{10}{|c|}{ (share of GDP) } \\
\hline Broad Money & 49.8 & 56.6 & 54.2 & 55.4 & 54.9 & 58.1 & 58.0 & 59.2 & 59.6 & 62.0 \\
\hline Claims on Nongovernment & 37.1 & 46.5 & 41.1 & 42.4 & 44.4 & 44.9 & 44.9 & 45.7 & 46.3 & 47.4 \\
\hline Claims on non-financial corporations & 24.5 & 31.6 & 26.0 & 26.3 & $\ldots$ & 27.5 & $\ldots$ & $\ldots$ & $\ldots$ & $\ldots$ \\
\hline Claims on households & 11.5 & 13.2 & 14.3 & 15.3 & $\ldots$ & 16.7 & $\ldots$ & $\ldots$ & $\ldots$ & $\ldots$ \\
\hline \multicolumn{11}{|l|}{ Memorandum items: } \\
\hline Reserve money (leva, million) & 7058 & 6,662 & 7,286 & 7,837 & 8,179 & 8,351 & 8,034 & 8,264 & 8,505 & 8,688 \\
\hline Banks' reserves (including cash in bank vault, Leva, millior & 2431 & 2,174 & 2,439 & 2,624 & 2,815 & 2,956 & 2,922 & 2,840 & 2,712 & 2,724 \\
\hline Money multiplier (M3/reserve money) & 2.7 & 3.3 & 2.9 & 2.9 & 2.8 & 2.9 & 3.1 & 3.1 & 3.1 & 3.3 \\
\hline BNB net foreign assets/Reserve money (in percent) & 164 & 173.3 & 178.1 & 163.0 & 155.9 & 159.8 & 166.4 & 166.1 & 172.0 & 165.6 \\
\hline Foreign currency deposits (percent of broad money) & 36 & 38.8 & 37.5 & 36.1 & 32.1 & 36.1 & 38.0 & 37.9 & 37.6 & 38.0 \\
\hline Commecial banks NFA/foreign currency deposits (in percent) & -5 & -8.0 & 0.7 & 1.9 & -12.2 & -1.3 & -0.8 & 6.1 & 3.8 & 12.0 \\
\hline Claims on nongovernment/deposits (in percent) & 95 & 99.5 & 93.7 & 95.5 & 106.0 & 95.3 & 93.6 & 93.5 & 94.7 & 92.4 \\
\hline Velocity M3 & 2.0 & 1.8 & 1.8 & 1.8 & $\ldots$ & 1.7 & 1.7 & 1.7 & 1.7 & 1.6 \\
\hline
\end{tabular}

Sources: BNB, National Statistics Institute, and Fund staff estimates. 
Table 10. Bulgaria: General Government Operations, 2001-2006 (In millions of leva)

\begin{tabular}{|c|c|c|c|c|c|c|c|}
\hline & \multirow[t]{2}{*}{2001} & \multirow{2}{*}{2002} & \multirow[t]{2}{*}{2003} & \multirow[t]{2}{*}{$20041 /$} & \multicolumn{2}{|c|}{2005} & \multirow{2}{*}{$\begin{array}{l}2006 \\
\text { Proj }\end{array}$} \\
\hline & & & & & First Rev. & Act. & \\
\hline Total revenue and grants & 11,124 & 11,750 & 13,053 & 14,918 & 16,037 & 17,030 & 18,454 \\
\hline Tax revenue & 8,518 & 8,882 & 10,215 & 11,869 & 12,764 & 13,579 & 14,677 \\
\hline Profit taxes & 1,150 & 976 & 1,032 & 973 & 981 & 1,028 & 1,093 \\
\hline Nonfinancial enterprises & 812 & 871 & 899 & 853 & 856 & 901 & 962 \\
\hline Financial enterprises & 339 & 104 & 133 & 119 & 125 & 127 & 132 \\
\hline Income taxes & 1,063 & 1,052 & 1,140 & 1,248 & 1,196 & 1,249 & 1,131 \\
\hline VAT & 2,454 & 2,688 & 3,101 & 3,891 & 4,317 & 4,798 & 5,538 \\
\hline Excise and fuel duties & 1,107 & 1,314 & 1,544 & 1,885 & 2,057 & 2,188 & 2,751 \\
\hline Customs duties & 195 & 188 & 231 & 292 & 278 & 372 & 444 \\
\hline Social insurance contributions & 2,312 & 2,361 & 2,808 & 3,171 & 3,540 & 3,505 & 3,247 \\
\hline Pension and unemployment contributions $2 /$ & 1,823 & 1,848 & 2,194 & 2,456 & 2,750 & 2,696 & 2,355 \\
\hline Health Insurance Fund & 489 & 513 & 614 & 715 & 790 & 809 & 892 \\
\hline Other taxes & 236 & 303 & 359 & 409 & 395 & 440 & 472 \\
\hline Nontax revenues & 2,243 & 2,566 & 2,527 & 2,595 & 2,754 & 2,935 & 3,090 \\
\hline BNB transfers & 175 & 173 & 133 & 171 & 147 & 149 & 150 \\
\hline Other & 2,069 & 2,393 & 2,394 & 2,424 & 2,607 & 2,786 & 2,940 \\
\hline Grants and donations & 363 & 302 & 311 & 455 & 520 & 516 & 688 \\
\hline Total expenditure and net lending 3 / & 11,384 & 12,025 & 13,202 & 14,248 & 15,620 & 16,055 & 17,067 \\
\hline Noninterest expenditure, net lending, contingency & 10,278 & 11,312 & 12,478 & 13,551 & 14,915 & 15,370 & 16,405 \\
\hline Current noninterest expenditure & 8,893 & 10,077 & 11,199 & 11,943 & 12,561 & 12,883 & 13,991 \\
\hline Compensation & 1,748 & 2,015 & 2,205 & 2,381 & 2,490 & 2,505 & 2,785 \\
\hline Wages and salaries & 1,711 & 1,974 & 2,159 & 2,335 & 2,445 & 2,459 & 2,739 \\
\hline Scholarships & 37 & 41 & 45 & 46 & 46 & 46 & 46 \\
\hline Maintenance and operations & 2,282 & 2,570 & 2,849 & 3,178 & 3,159 & 3,475 & 3,573 \\
\hline Subsidies & 709 & 773 & 888 & 869 & 748 & 870 & 592 \\
\hline Social expenditures & 4,074 & 4,653 & 5,109 & 5,445 & 6,064 & 5,987 & 6,941 \\
\hline Pension fund & 2,586 & 2,944 & 3,161 & 3,457 & 3,668 & 3,715 & 4,073 \\
\hline Assistance and unemployment & 858 & 1,007 & 1,004 & 941 & 1,226 & 1,032 & 1,341 \\
\hline Health Insurance Fund & 404 & 498 & 720 & 778 & 896 & 947 & 1,219 \\
\hline Other social expenditures 4 / & 226 & 204 & 224 & 269 & 274 & 293 & 308 \\
\hline Transfers $5 /$ & 79 & 66 & 150 & 71 & 100 & 46 & 100 \\
\hline Capital expenditures & 1,158 & 1,045 & 1,191 & 1,473 & 1,929 & 2,039 & 2,081 \\
\hline Contingency & 227 & 189 & 88 & 219 & 426 & 439 & 333 \\
\hline Enterprise restructuring & 0 & 0 & 0 & 0 & 15 & 4 & 20 \\
\hline Budget & 188 & 143 & 42 & 168 & 356 & 317 & 193 \\
\hline Natural disaster & 39 & 46 & 46 & 51 & 56 & 118 & 120 \\
\hline Primary balance & 847 & 438 & 575 & 1,368 & 1,122 & 1,660 & 2,049 \\
\hline Interest & 1,106 & 713 & 724 & 697 & 705 & 686 & 662 \\
\hline External & 853 & 544 & 561 & 517 & 507 & 494 & 445 \\
\hline Domestic & 253 & 169 & 163 & 181 & 198 & 192 & 217 \\
\hline Overall balance & -259 & -275 & -149 & 670 & 417 & 974 & 1,387 \\
\hline Financing & 259 & 275 & 149 & -670 & -417 & -974 & $-1,387$ \\
\hline Privatization 6/ & 861 & 417 & 391 & 1,180 & 1,791 & 1,447 & 293 \\
\hline External (net) & -96 & 481 & -2 & -622 & $-1,975$ & $-2,411$ & -332 \\
\hline Domestic (net) & -506 & -623 & -240 & $-1,228$ & -233 & -11 & $-1,348$ \\
\hline \multicolumn{8}{|l|}{ Memorandum item: } \\
\hline Nominal GDP in millions of leva & 29,709 & 32,335 & 34,547 & 38,009 & 41,302 & 41,570 & 46,221 \\
\hline
\end{tabular}

Sources: Ministry of Finance; and Fund staff projections.

1/ In late 2004, a state enterprise for infrastructure projects ("PIP") was created, capitalized with BGN 340 million to execute spending in 2005. PIP is consolidated with the general government.

2/ Pension and unemployment contributions were combined in January 2002.

3/ From 2004, total expenditure is adjusted for variation of arrears (net). Net variation in arrears amounted to BGN -84.7 million and BGN 8.2 million in 2004 and 2005, respectively.

4/ Includes additional compulsory social security contributions (for the second pillar of the pension system) for public sector employees. 5/ Under the 2003 and 2004 budgets, these transfers were envisaged to be made below the line for various purposes.

6/ Slight differences between privatization receipts in the balance of payments and the fiscal accounts are due to domestic privatization. In 2004, however, about BGN 500 million (1.3 percent of GDP) of previously completed bank privatizations was transferred to the government upon the closure of the Bank Consolidation Company. 
Table 11. Bulgaria: General Government Operations, 2001-2006 (In percent of GDP)

\begin{tabular}{|c|c|c|c|c|c|c|c|}
\hline & \multirow[t]{2}{*}{2001} & \multirow[t]{2}{*}{2002} & \multirow[t]{2}{*}{2003} & \multirow[t]{2}{*}{$20041 /$} & \multicolumn{2}{|c|}{2005 Full Year } & \multirow{2}{*}{$\begin{array}{l}200 \\
\text { Proj }\end{array}$} \\
\hline & & & & & First Rev. & Act. & \\
\hline Total revenue and grants & 37.4 & 36.3 & 37.8 & 39.3 & 38.8 & 41.0 & 39.9 \\
\hline Tax revenue & 28.7 & 27.5 & 29.6 & 31.2 & 30.9 & 32.7 & 31.8 \\
\hline Profit taxes & 3.9 & 3.0 & 3.0 & 2.6 & 2.4 & 2.5 & 2.4 \\
\hline Nonfinancial enterprises & 2.7 & 2.7 & 2.6 & 2.2 & 2.1 & 2.2 & 2.1 \\
\hline Financial enterprises & 1.1 & 0.3 & 0.4 & 0.3 & 0.3 & 0.3 & 0.3 \\
\hline Income taxes & 3.6 & 3.3 & 3.3 & 3.3 & 2.9 & 3.0 & 2.4 \\
\hline VAT & 8.3 & 8.3 & 9.0 & 10.2 & 10.5 & 11.5 & 12.0 \\
\hline Excise and fuel duties & 3.7 & 4.1 & 4.5 & 5.0 & 5.0 & 5.3 & 6.0 \\
\hline Customs duties & 0.7 & 0.6 & 0.7 & 0.8 & 0.7 & 0.9 & 1.0 \\
\hline Social insurance contributions & 7.8 & 7.3 & 8.1 & 8.3 & 8.6 & 8.4 & 7.0 \\
\hline Pension and unemployment contributions $2 /$ & 6.1 & 5.7 & 6.4 & 6.5 & 6.7 & 6.5 & 5.1 \\
\hline Health Insurance Fund & 1.6 & 1.6 & 1.8 & 1.9 & 1.9 & 1.9 & 1.9 \\
\hline Other taxes & 0.8 & 0.9 & 1.0 & 1.1 & 1.0 & 1.1 & 1.0 \\
\hline Nontax revenues & 7.6 & 7.9 & 7.3 & 6.8 & 6.7 & 7.1 & 6.7 \\
\hline BNB transfers & 0.6 & 0.5 & 0.4 & 0.4 & 0.4 & 0.4 & 0.3 \\
\hline Other & 7.0 & 7.4 & 6.9 & 6.4 & 6.3 & 6.7 & 6.4 \\
\hline Grants and donations & 1.2 & 0.9 & 0.9 & 1.2 & 1.3 & 1.2 & 1.5 \\
\hline Total expenditure and net lending 3 / & 38.3 & 37.2 & 38.2 & 37.5 & 37.8 & 38.6 & 36.9 \\
\hline Noninterest expenditure, net lending, contingency & 34.6 & 35.0 & 36.1 & 35.7 & 36.1 & 37.0 & 35.5 \\
\hline Current noninterest expenditure & 29.9 & 31.2 & 32.4 & 31.4 & 30.4 & 31.0 & 30.3 \\
\hline Compensation & 5.9 & 6.2 & 6.4 & 6.3 & 6.0 & 6.0 & 6.0 \\
\hline Wages and salaries & 5.8 & 6.1 & 6.2 & 6.1 & 5.9 & 5.9 & 5.9 \\
\hline Scholarships & 0.1 & 0.1 & 0.1 & 0.1 & 0.1 & 0.1 & 0.1 \\
\hline Maintenance and operations & 7.7 & 7.9 & 8.2 & 8.4 & 7.6 & 8.4 & 7.7 \\
\hline Subsidies & 2.4 & 2.4 & 2.6 & 2.3 & 1.8 & 2.1 & 1.3 \\
\hline Social expenditures & 13.7 & 14.4 & 14.8 & 14.3 & 14.7 & 14.4 & 15.0 \\
\hline Pension fund & 8.7 & 9.1 & 9.2 & 9.1 & 8.9 & 8.9 & 8.8 \\
\hline Assistance and unemployment & 2.9 & 3.1 & 2.9 & 2.5 & 3.0 & 2.5 & 2.9 \\
\hline Health Insurance Fund & 1.4 & 1.5 & 2.1 & 2.0 & 2.2 & 2.3 & 2.6 \\
\hline Other social expenditures 4 / & 0.8 & 0.6 & 0.6 & 0.7 & 0.7 & 0.7 & 0.7 \\
\hline Transfers $5 /$ & $\ldots$ & $\ldots$ & 0.4 & 0.2 & 0.2 & 0.1 & 0.2 \\
\hline Capital expenditures & 3.9 & 3.2 & 3.4 & 3.9 & 4.7 & 4.9 & 4.5 \\
\hline Contingency & 0.8 & 0.6 & 0.3 & 0.6 & 1.0 & 1.1 & 0.7 \\
\hline Enterprise restructuring & 0.0 & 0.0 & 0.0 & 0.0 & 0.0 & 0.0 & 0.0 \\
\hline Budget & 0.6 & 0.4 & 0.1 & 0.4 & 0.9 & 0.8 & 0.4 \\
\hline Natural disaster & 0.1 & 0.1 & 0.1 & 0.1 & 0.1 & 0.3 & 0.3 \\
\hline Primary balance & 2.8 & 1.4 & 1.7 & 3.6 & 2.7 & 4.0 & 4.4 \\
\hline Interest & 3.7 & 2.2 & 2.1 & 1.8 & 1.7 & 1.6 & 1.4 \\
\hline External & 2.9 & 1.7 & 1.6 & 1.4 & 1.2 & 1.2 & 1.0 \\
\hline Domestic & 0.9 & 0.5 & 0.5 & 0.5 & 0.5 & 0.5 & 0.5 \\
\hline Overall balance & -0.9 & -0.8 & -0.4 & 1.8 & 1.0 & 2.3 & 3.0 \\
\hline Financing & 0.9 & 0.8 & 0.4 & -1.8 & -1.0 & -2.3 & -3.0 \\
\hline Privatization 6/ & 2.9 & 1.3 & 1.1 & 3.1 & 4.3 & 3.5 & 0.6 \\
\hline External (net) & -0.3 & 1.5 & 0.0 & -1.6 & -4.8 & -5.8 & -0.7 \\
\hline Domestic (net) & -1.7 & -1.9 & -0.7 & -3.2 & -0.6 & 0.0 & -2.9 \\
\hline Public debt & 69.9 & 56.3 & 48.2 & 40.9 & 33.3 & 32.2 & 28.8 \\
\hline External & 63.7 & 49.7 & 41.6 & 33.9 & 26.4 & 25.4 & 21.3 \\
\hline Domestic & 6.3 & 6.6 & 6.5 & 7.1 & 6.8 & 6.8 & 7.5 \\
\hline \multicolumn{8}{|l|}{ Memorandum item: } \\
\hline Nominal GDP in millions of leva & 29,709 & 32,335 & 34,547 & 38,009 & 41,302 & 41,570 & 46,221 \\
\hline
\end{tabular}

Sources: Ministry of Finance; and Fund staff projections.

1/ In late 2004, a state enterprise for infrastructure projects ("PIP") was created, capitalized with BGN 340 million to execute spending in 2005. PIP is consolidated with the general government.

2/ Pension and unemployment contributions were combined in January 2002

3/ From 2004, total expenditure is adjusted for variation of arrears (net). Net variation in arrears amounted to BGN -84.7 million and BGN 8.2 million in 2004 and 2005, respectively.

4/ Includes additional compulsory social security contributions (for the second pillar of the pension system) for public sector employees. 5/ Under the 2003 and 2004 budgets, these transfers were envisaged to be made below the line for various purposes.

6/ Slight differences between privatization receipts in the balance of payments and the fiscal accounts are due to domestic privatization. In 2004, however, about BGN 500 million (1.3 percent of GDP) of previously completed bank privatizations was transferred to the government upon the closure of the Bank Consolidation Company. 
Table 12. Bulgaria: Balance of Payments, 2002-2011 (In millions of euros)

\begin{tabular}{|c|c|c|c|c|c|c|c|c|c|c|}
\hline & 2002 & 2003 & 2004 & 2005 & 2006 & 2007 & 2008 & 2009 & 2010 & 2011 \\
\hline & & & & & \multicolumn{6}{|c|}{ Projections } \\
\hline CURRENT ACCOUNT & -925 & $-1,631$ & $-1,648$ & $-3,163$ & $-3,049$ & $-2,742$ & $-2,898$ & $-2,788$ & $-2,854$ & $-2,552$ \\
\hline Trade balance & $-1,692$ & $-2,200$ & $-2,729$ & $-4,083$ & $-4,372$ & $-4,575$ & $-5,029$ & $-5,283$ & $-5,379$ & $-5,277$ \\
\hline Exports (f.o.b.) & 6,063 & 6,668 & 7,985 & 9,454 & 11,585 & 12,638 & 13,252 & 14,369 & 15,670 & 17,419 \\
\hline$y$-o-y change (in percent) & 6.1 & 10.0 & 19.7 & 18.4 & 22.5 & 9.1 & 4.9 & 8.4 & 9.1 & 11.2 \\
\hline Imports (f.o.b.) & $-7,755$ & $-8,868$ & $-10,714$ & $-13,537$ & $-15,957$ & $-17,213$ & $-18,281$ & $-19,652$ & $-21,049$ & $-22,695$ \\
\hline $\mathrm{y}$-o-y change (in percent) & 3.5 & 14.4 & 20.8 & 26.3 & 17.9 & 7.9 & 6.2 & 7.5 & 7.1 & 7.8 \\
\hline Services, net & 486 & 523 & 723 & 532 & 777 & 1,043 & 1,222 & 1,421 & 1,605 & 1,836 \\
\hline Exports of NFS & 2,479 & 2,791 & 3,362 & 3,587 & 4,219 & 4,699 & 5,085 & 5,523 & 5,949 & 6,460 \\
\hline Imports of NFS & $-1,993$ & $-2,268$ & $-2,639$ & $-3,054$ & $-3,442$ & $-3,656$ & $-3,863$ & $-4,103$ & $-4,344$ & $-4,624$ \\
\hline Of which: Exports of travel services & 1,203 & 1,460 & 1,746 & 1,888 & 2,199 & 2,474 & 2,752 & 3,006 & 3,214 & 3,434 \\
\hline Income, net $1 /$ & -285 & -567 & -531 & -551 & -561 & -865 & $-1,070$ & $-1,270$ & $-1,373$ & $-1,604$ \\
\hline Of which: Income to direct investors & -237 & -493 & -456 & -522 & -507 & -670 & -825 & -958 & $-1,060$ & $-1,261$ \\
\hline Current transfers, net & 566 & 613 & 888 & 938 & 1,106 & 1,655 & 1,980 & 2,344 & 2,292 & 2,493 \\
\hline CAPITAL AND FINANCIAL ACCOUNT & 1,657 & 2,412 & 3,186 & 3,847 & 3,938 & 3,642 & 3,732 & 3,339 & 3,436 & 3,002 \\
\hline Capital transfers, net & 0 & 0 & 0 & -1 & 0 & 0 & 0 & 0 & 0 & 0 \\
\hline Foreign direct investment, net $2 / 3$ / & 951 & 1,827 & 1,104 & 2,297 & 2,229 & 2,276 & 2,206 & 2,100 & 2,133 & 2,187 \\
\hline Of which: Privatization receipts $4 /$ & 144 & 312 & 243 & 693 & 150 & 223 & 150 & 0 & 0 & 0 \\
\hline Portfolio investment, net & -99 & -191 & -557 & -757 & 46 & -186 & 76 & 76 & 76 & 76 \\
\hline Other investment, net & 1,006 & 840 & 2,220 & 1,274 & 1,664 & 1,552 & 1,451 & 1,163 & 1,227 & 739 \\
\hline General government & -129 & 60 & 102 & 55 & 49 & 415 & 254 & 179 & 146 & 130 \\
\hline Domestic banks & 443 & 562 & 1,036 & -177 & -786 & 105 & 403 & 47 & 50 & 600 \\
\hline Other private sector & 691 & 219 & 1,081 & 1,396 & 2,400 & 1,031 & 794 & 938 & 1,031 & 9 \\
\hline Errors and omissions & -201 & -64 & 419 & 1,034 & 0 & 0 & 0 & 0 & 0 & 0 \\
\hline OVERALL BALANCE & 732 & 781 & 1,538 & 684 & 889 & 900 & 835 & 551 & 582 & 450 \\
\hline FINANCING & -732 & -781 & $-1,538$ & -684 & -889 & -900 & -835 & -551 & -582 & -450 \\
\hline Gross international reserves (increase: -) & -578 & -817 & $-1,493$ & -324 & -605 & -805 & -740 & -488 & -561 & -450 \\
\hline Use of Fund credit, net & -155 & 35 & -44 & -359 & -284 & -95 & -95 & -63 & -21 & 0 \\
\hline Purchases & 117 & 128 & 62 & 0 & 0 & 0 & 0 & 0 & 0 & 0 \\
\hline Repurchases 5/ & -270 & -101 & -106 & -359 & -284 & -95 & -95 & -63 & -21 & 0 \\
\hline Exceptional financing & 0 & 0 & 0 & 0 & 0 & 0 & 0 & 0 & 0 & 0 \\
\hline \multicolumn{11}{|l|}{ MEMORANDUM ITEMS } \\
\hline Gross international reserves (stock, e.o.p.) 6/ & 4,575 & 5,405 & 6,854 & 7,370 & 7,975 & 8,780 & 9,520 & 10,008 & 10,569 & 11,018 \\
\hline In months of prospective GNFS imports & 4.9 & 4.9 & 5.0 & 4.6 & 4.5 & 4.7 & 4.7 & 4.7 & 4.6 & $\ldots$ \\
\hline In percent of short-term debt (original maturity) & 301.9 & 354.5 & 276.7 & 200.6 & 166.8 & 172.1 & 171.7 & 163.5 & 154.8 & 152.2 \\
\hline Current account + FDI & 26 & 196 & -544 & -866 & -820 & -466 & -692 & -689 & -721 & -365 \\
\hline (in percent of GDP) & 0.2 & 1.1 & -2.8 & -4.1 & -3.5 & -1.8 & -2.5 & -2.3 & -2.2 & -1.0 \\
\hline Current account (in percent of GDP) & -5.6 & -9.2 & -8.5 & -14.9 & -12.9 & -10.6 & -10.4 & -9.1 & -8.6 & -7.0 \\
\hline Merchandise trade account (in percent of GDP) & -10.2 & -12.5 & -14.0 & -19.2 & -18.5 & -17.7 & -18.0 & -17.3 & -16.1 & -14.5 \\
\hline Merchandise exports (in percent of GDP) & 36.7 & 37.8 & 41.1 & 44.5 & 49.0 & 49.0 & 47.3 & 47.1 & 47.0 & 47.7 \\
\hline Merchandise imports (in percent of GDP) & -46.9 & -50.2 & -55.1 & -63.7 & -67.5 & -66.7 & -65.3 & -64.5 & -63.1 & -62.2 \\
\hline Export volume (year-on-year change) & 9.9 & 15.2 & 8.8 & 4.1 & 13.3 & 14.2 & 10.0 & 10.5 & 10.9 & 10.8 \\
\hline Import volume (year-on-year change) & 7.5 & 19.5 & 12.8 & 10.9 & 9.4 & 12.0 & 10.1 & 9.1 & 8.4 & 7.5 \\
\hline FDI (net) in percent of current account & 102.8 & 112.0 & 67.0 & 72.6 & 73.1 & 83.0 & 76.1 & 75.3 & 74.7 & 85.7 \\
\hline Gross external debt (stock, e.o.p.) 7/ & 10,769 & 10,641 & 12,522 & 14,325 & 16,182 & 17,094 & 18,126 & 19,325 & 20,834 & 21,642 \\
\hline (In percent of GDP) & 65.1 & 60.2 & 64.4 & 67.4 & 68.5 & 66.2 & 64.8 & 63.4 & 62.5 & 59.3 \\
\hline Public & 7,961 & 7,048 & 6,429 & 5,139 & 5,253 & 5,656 & 6,026 & 6,252 & 6,462 & 6,652 \\
\hline Private & 2,808 & 3,593 & 6,093 & 9,186 & 10,929 & 11,438 & 12,101 & 13,073 & 14,372 & 11,639 \\
\hline Short-term debt (in percent of total debt, e.o.p.) & 14.1 & 14.3 & 19.8 & 25.6 & 28.8 & 29.3 & 30.2 & 31.4 & 32.6 & 33.5 \\
\hline Net external debt (in percent of annual GDP) 8/ & 25.7 & 20.9 & 17.4 & 21.5 & 22.0 & 21.3 & 21.5 & 21.5 & 21.3 & 20.0 \\
\hline GDP & 16,533 & 17,663 & 19,433 & 21,254 & 23,632 & 25,816 & 27,988 & 30,482 & 33,342 & 36,487 \\
\hline
\end{tabular}

Sources: Bulgarian authorities; and Fund staff estimates.

1/ Revisions to the 2004 data since the May 2004 Board meeting have led to a deterioration of about 0.8 percent of GDP.

2/ All FDI are assumed to be non-debt creating in the projections.

3/ The figures for 2004 and 2005 are influenced by a complex debt financed merger and acquisition transaction of a local mobile telephone

company that led to a sharp increase in its equity value, and a transfer of the realized capital gains out of the country by the original owners. This resulted in a net

FDI outflow of 650 million euros and an increase in gross external debt by 590 million euros in 2004

4/ Privatization receipts for the electricity distribution companies are included in 2005. These are included in the receipts for 2004 in the balance of payments presentation of

the BNB. The present treatment aligns them with its receipt in the fiscal accounts

5/ According to expectations schedule.

6/ Historical numbers include valuation changes. From 2006-10 includes reserves posted as a guarantee for defense related purchases. Reserve coverage ratios are calculated net

of impaired reserves.

7/ Projections include assumptions on disbursements related to debt not already contracted.

8/ External debt minus gross foreign assets of the banking system. 
Table 13. Bulgaria: Macroeconomic Framework, 2002-2011

\begin{tabular}{|c|c|c|c|c|c|c|c|c|c|c|c|}
\hline & 2002 & 2003 & 2004 & 2005 & 2005 & 2006 & 2007 & 2008 & 2009 & 2010 & 2011 \\
\hline & & & & First Rev. & \multicolumn{7}{|c|}{ Projections } \\
\hline \multicolumn{12}{|l|}{ GDP and prices (annual percent change) } \\
\hline Real GDP & 4.9 & 4.5 & 5.6 & 5.5 & 5.6 & 5.5 & 5.9 & 6.0 & 6.1 & 6.1 & 6.1 \\
\hline GDP deflator & 3.8 & 2.3 & 4.2 & 3.0 & 3.6 & 5.4 & 3.2 & 2.2 & 2.7 & 3.1 & 3.2 \\
\hline CPI (end of period) & 3.8 & 5.6 & 4.0 & 3.5 & 6.5 & 5.7 & 2.7 & 2.5 & 3.4 & 3.4 & 3.5 \\
\hline (period average) & 5.8 & 2.3 & 6.1 & 4.0 & 5.0 & 6.9 & 3.5 & 2.5 & 3.0 & 3.4 & 3.5 \\
\hline \multicolumn{12}{|l|}{ Monetary aggregates (annual percent change) } \\
\hline Broad money (nominal, end of period) & 11.9 & 20.9 & 21.6 & 19.8 & 27.7 & 18.6 & 14.4 & 12.1 & 10.4 & 10.4 & 9.2 \\
\hline Claims on non-government (nominal, end of period) & 44.0 & 48.3 & 48.7 & 30.0 & 32.3 & 17.5 & 16.9 & 15.1 & 10.3 & 10.0 & 10.0 \\
\hline \multicolumn{12}{|l|}{ Saving and investment (in percent of GDP) } \\
\hline Foreign saving $1 /$ & 7.3 & 9.5 & 10.3 & 10.4 & 16.7 & 15.2 & 13.7 & 13.6 & 12.7 & 11.3 & 9.4 \\
\hline Gross national saving & 14.2 & 12.5 & 15.0 & 17.4 & 13.1 & 15.7 & 19.5 & 20.4 & 21.8 & 22.5 & 24.1 \\
\hline Gross domestic saving $2 /$ & 12.5 & 12.2 & 13.2 & 14.5 & 11.2 & 13.4 & 16.4 & 17.2 & 18.3 & 19.8 & 21.7 \\
\hline Government & 4.1 & 4.6 & 7.0 & 6.7 & 8.4 & 8.5 & 8.7 & 8.5 & 8.2 & 7.7 & 7.5 \\
\hline Non-government & 8.4 & 7.6 & 6.2 & 7.8 & 2.8 & 4.9 & 7.7 & 8.7 & 10.1 & 12.0 & 14.1 \\
\hline Gross domestic investment & 19.8 & 21.7 & 23.5 & 25.0 & 27.9 & 28.6 & 30.1 & 30.8 & 31.0 & 31.1 & 31.1 \\
\hline Government & 3.2 & 3.4 & 3.9 & 4.5 & 4.9 & 4.5 & 6.3 & 6.5 & 6.6 & 6.6 & 6.6 \\
\hline Non-government & 16.6 & 18.3 & 19.6 & 20.5 & 23.0 & 24.1 & 23.8 & 24.3 & 24.4 & 24.5 & 24.5 \\
\hline \multicolumn{12}{|l|}{ General government (in percent of GDP) } \\
\hline Revenue & 36.3 & 37.8 & 39.3 & 38.8 & 41.0 & 39.9 & 41.3 & 40.9 & 40.6 & 40.3 & 40.0 \\
\hline Non-interest expenditure & 35.0 & 36.1 & 35.7 & 36.1 & 37.0 & 35.5 & 38.5 & 38.7 & 38.7 & 39.0 & 38.9 \\
\hline Primary balance & 1.4 & 1.7 & 3.6 & 2.7 & 4.0 & 4.4 & 2.7 & 2.3 & 1.9 & 1.4 & 1.1 \\
\hline Interest payments & 2.2 & 2.1 & 1.8 & 1.7 & 1.6 & 1.4 & 1.4 & 1.3 & 1.1 & 1.0 & 0.9 \\
\hline Overall balance 3 / & -0.8 & -0.4 & 1.8 & 1.0 & 2.3 & 3.0 & 1.3 & 1.0 & 0.7 & 0.4 & 0.3 \\
\hline Total public debt & 56.3 & 48.2 & 40.9 & 33.3 & 32.2 & 28.8 & 26.0 & 23.5 & 20.8 & 18.4 & 16.3 \\
\hline Of which: External & 49.7 & 41.6 & 33.9 & 26.4 & 25.4 & 21.3 & 19.0 & 17.0 & 14.7 & 12.7 & 10.9 \\
\hline \multicolumn{12}{|l|}{ Balance of payments (in percent of GDP) } \\
\hline Current account & -5.6 & -9.2 & -8.5 & -7.6 & -14.9 & -12.9 & -10.6 & -10.4 & -9.1 & -8.6 & -7.0 \\
\hline Trade balance & -10.2 & -12.5 & -14.0 & -14.9 & -19.2 & -18.5 & -17.7 & -18.0 & -17.3 & -16.1 & -14.5 \\
\hline Exports & 36.7 & 37.8 & 41.1 & 43.8 & 44.5 & 49.0 & 49.0 & 47.3 & 47.1 & 47.0 & 47.7 \\
\hline Imports & 46.9 & 50.2 & 55.1 & 58.7 & 63.7 & 67.5 & 66.7 & 65.3 & 64.5 & 63.1 & 62.2 \\
\hline Services, net & 2.9 & 3.0 & 3.7 & 4.4 & 2.5 & 3.3 & 4.0 & 4.4 & 4.7 & 4.8 & 5.0 \\
\hline Receipts & 15.0 & 15.8 & 17.3 & 18.5 & 16.9 & 17.9 & 18.2 & 18.2 & 18.1 & 17.8 & 17.7 \\
\hline Payments & 12.1 & 12.8 & 13.6 & 14.1 & 14.4 & 14.6 & 14.2 & 13.8 & 13.5 & 13.0 & 12.7 \\
\hline Income, net & -1.7 & -3.2 & -2.7 & -1.9 & -2.6 & -2.4 & -3.4 & -3.8 & -4.2 & -4.1 & -4.4 \\
\hline \multicolumn{12}{|l|}{ Memorandum items } \\
\hline $\begin{array}{l}\text { Gross official reserves (in millions of euros) } \\
\text { (in months of prospective imports of GNFS) }\end{array}$ & $\begin{array}{r}4,575 \\
4.9\end{array}$ & $\begin{array}{r}5,405 \\
4.9\end{array}$ & $\begin{array}{r}6,854 \\
5.0\end{array}$ & $\begin{array}{r}7,196 \\
5.2\end{array}$ & $\begin{array}{r}7,370 \\
4.6\end{array}$ & $\begin{array}{r}7,975 \\
4.5\end{array}$ & $\begin{array}{r}8,780 \\
4.7\end{array}$ & $\begin{array}{r}9,520 \\
4.8\end{array}$ & $\begin{array}{r}10,008 \\
4.7\end{array}$ & $\begin{array}{r}10,569 \\
4.6\end{array}$ & $\begin{array}{r}11,018 \\
\ldots\end{array}$ \\
\hline External debt/GDP (in percent) & 65.1 & 60.2 & 64.4 & 57.5 & 67.4 & 68.5 & 66.2 & 64.8 & 63.4 & 62.5 & 59.3 \\
\hline External debt/exports of GNFS (in percent) & 126.1 & 112.5 & 110.4 & 92.3 & 109.8 & 102.4 & 98.6 & 98.9 & 97.2 & 96.4 & 90.6 \\
\hline External debt service/exports of GNFS (in percent) & 15.9 & 13.9 & 21.4 & 17.3 & 41.4 & 9.4 & 11.1 & 11.1 & 11.7 & 12.3 & 13.3 \\
\hline Export volume (year-on-year change) & 9.9 & 15.2 & 8.8 & $\ldots$ & 4.1 & 13.3 & 14.2 & 10.0 & 10.5 & 10.9 & 10.8 \\
\hline Import volume (year-on-year change) & 7.5 & 19.5 & 12.8 & $\ldots$ & 10.9 & 9.4 & 12.0 & 10.1 & 9.1 & 8.4 & 7.5 \\
\hline Terms of trade (percent change) & 0.2 & -0.3 & 2.7 & -1.1 & -0.1 & 0.4 & -0.8 & -1.2 & -0.4 & -0.4 & 0.1 \\
\hline Nominal GDP (in millions of leva) & 32,335 & 34,547 & 38,009 & 41,302 & 41,570 & 46,221 & 50,492 & 54,740 & 59,618 & 65,212 & 71,362 \\
\hline Nominal GDP (in millions of euros) & 16,533 & 17,663 & 19,433 & 21,117 & 21,254 & 23,632 & 25,816 & 27,988 & 30,482 & 33,342 & 36,487 \\
\hline
\end{tabular}

Sources: Bulgarian authorities; and Fund staff projections.

1/ Net imports of goods and nonfactor services.

2/ Gross domestic saving equals gross national saving less net factor income and transfers from abroad. The government

contribution to gross domestic saving equals revenues less current expenditures, excluding external interest payments.

3/ From 2003 onwards, includes below-the-line transfers. In 2003, balance excluding below-the-line transfers was 0.0 percent of GDP. 
Table 14. Bulgaria: External Debt Sustainability Framework, 2001-2011

(In percent of GDP, unless otherwise indicated)

\begin{tabular}{|c|c|c|c|c|c|c|c|c|c|c|c|c|}
\hline & \multicolumn{5}{|c|}{ Actual } & \multicolumn{7}{|c|}{ Projections } \\
\hline & 2001 & 2002 & 2003 & 2004 & $2005^{7 /}$ & 2006 & 2007 & 2008 & 2009 & 2010 & 2011 & Debt-stabilizing \\
\hline 1 Baseline: External debt & 78.6 & 65.1 & 60.2 & 64.4 & 67.4 & 68.5 & 66.2 & 64.8 & 63.4 & 62.5 & 59.3 & $\begin{array}{c}\text { current account } 6 / \\
-8.2\end{array}$ \\
\hline 2 Change in external debt & -8.5 & -13.5 & -4.9 & 4.2 & 3.0 & 1.1 & -2.3 & -1.4 & -1.4 & -0.9 & -3.2 & \\
\hline 3 Identified external debt-creating flows $(4+8+9)$ & -6.8 & -5.1 & -4.0 & -2.7 & -1.4 & 0.1 & -1.9 & -1.2 & -1.4 & -1.4 & -2.5 & \\
\hline $4 \quad$ Current account deficit, excluding interest payments & 3.5 & 3.3 & 7.2 & 6.7 & 12.8 & 11.1 & 8.0 & 7.6 & 6.2 & 5.6 & 3.9 & \\
\hline Deficit in balance of goods and services & 8.7 & 7.3 & 9.5 & 10.3 & 16.7 & 15.2 & 13.7 & 13.6 & 12.7 & 11.3 & 9.4 & \\
\hline Exports & 53.3 & 51.7 & 53.5 & 58.4 & 61.4 & 66.9 & 67.2 & 65.5 & 65.3 & 64.8 & 65.4 & \\
\hline Imports & 62.1 & 59.0 & 63.0 & 68.7 & 78.1 & 82.1 & 80.8 & 79.1 & 77.9 & 76.2 & 74.9 & \\
\hline Net non-debt creating capital inflows (negative) & -5.2 & -4.3 & -9.1 & -5.7 & -10.8 & -9.4 & -8.8 & -7.9 & -6.9 & -6.4 & -6.0 & \\
\hline Automatic debt dynamics $1 /$ & -5.1 & -4.1 & -2.1 & -3.7 & -3.4 & -1.5 & -1.1 & -0.9 & -0.7 & -0.6 & -0.4 & \\
\hline Contribution from nominal interest rate & 3.7 & 2.3 & 2.1 & 1.8 & 2.1 & 1.8 & 2.6 & 2.7 & 2.9 & 3.0 & 3.0 & \\
\hline Contribution from real GDP growth & -3.2 & -3.5 & -2.7 & -3.0 & -3.3 & -3.3 & -3.7 & -3.7 & -3.6 & -3.5 & -3.5 & \\
\hline Contribution from price and exchange rate changes $2 /$ & -5.6 & -2.9 & -1.5 & -2.4 & -2.2 & $\ldots$ & $\ldots$ & $\ldots$ & $\ldots$ & $\ldots$ & $\ldots$ & \\
\hline 13 Residual, incl. change in gross foreign assets (2-3) 3/ & -1.7 & -8.3 & -0.9 & 6.9 & 4.4 & 0.9 & -0.4 & -0.2 & 0.0 & 0.5 & -0.7 & \\
\hline External debt-to-exports ratio (in percent) & 147.4 & 126.1 & 112.5 & 110.4 & 109.8 & 102.4 & 98.6 & 98.9 & 97.2 & 96.4 & 90.6 & \\
\hline $\begin{array}{l}\text { Gross external financing need (in billions of Euros) } 4 \text { / } \\
\text { in percent of GDP }\end{array}$ & 3.5 & 3.1 & 3.8 & 4.7 & 9.3 & 7.8 & 8.5 & 8.9 & 9.4 & 10.1 & 10.7 & \\
\hline \multicolumn{2}{|l|}{ Scenario with key variables at their historical averages 5 / } & & & & & 68.5 & 64.4 & 59.9 & 56.0 & 53.1 & 48.8 & -6.8 \\
\hline \multicolumn{13}{|l|}{ Key Macroeconomic Assumptions Underlying Baseline } \\
\hline Real GDP growth (in percent) & 4.1 & 4.9 & 4.5 & 5.6 & 5.6 & 5.5 & 5.9 & 6.0 & 6.1 & 6.1 & 6.1 & \\
\hline GDP deflator in Euros (change in percent) & 6.9 & 3.8 & 2.3 & 4.2 & 3.6 & 5.4 & 3.2 & 2.2 & 2.7 & 3.1 & 3.2 & \\
\hline Nominal external interest rate (in percent) & 4.8 & 3.2 & 3.4 & 3.3 & 3.6 & 3.0 & 4.1 & 4.5 & 4.9 & 5.1 & 5.3 & \\
\hline Growth of exports (Euro terms, in percent) & 6.3 & 5.5 & 10.7 & 20.0 & 14.9 & 21.2 & 9.7 & 5.8 & 8.5 & 8.7 & 10.5 & \\
\hline Growth of imports (Euro terms, in percent) & 12.8 & 3.4 & 14.2 & 19.9 & 24.3 & 16.9 & 7.6 & 6.1 & 7.3 & 6.9 & 7.6 & \\
\hline Current account balance, excluding interest payments & -3.5 & -3.3 & -7.2 & -6.7 & -12.8 & -11.1 & -8.0 & -7.6 & -6.2 & -5.6 & -3.9 & \\
\hline Net non-debt creating capital inflows & 5.2 & 4.3 & 9.1 & 5.7 & 10.8 & 9.4 & 8.8 & 7.9 & 6.9 & 6.4 & 6.0 & \\
\hline
\end{tabular}

Sources: Bulgarian authorities; and Fund staff estimates.

1/ Derived as $[\mathrm{r}-\mathrm{g}-\rho(1+\mathrm{g})+\varepsilon \alpha(1+\mathrm{r})] /(1+\mathrm{g}+\rho+\mathrm{g} \rho)$ times previous period debt stock, with $\mathrm{r}=$ nominal effective interest rate on external debt; $\rho=$ change in domestic GDP deflator in Euro terms, $\mathrm{g}=$ real GDP growth rate, $\varepsilon=$ nominal appreciation (increase in euro value of domestic currency), and $\alpha=$ share of domestic-currency denominated debt in total external debt.

$2 /$ The contribution from price and exchange rate changes is defined as $[-\rho(1+g)+\varepsilon \alpha(1+\mathrm{r})] /(1+\mathrm{g}+\rho+g \rho)$ times previous period debt stock. $\rho$ increases with an appreciating domestic currency $(\varepsilon>0)$

and rising inflation (based on GDP deflator).

3/ For projection, line includes the impact of price and exchange rate changes.

4/ Defined as current account deficit, plus amortization on medium- and long-term debt, plus short-term debt at end of previous period.

5/ The key variables include real GDP growth; nominal interest rate; euro deflator growth; and both non-interest current account and non-debt inflows in percent of GDP.

6/ Long-run, constant balance that stabilizes the debt ratio assuming that key variables (real GDP growth, nominal interest rate, euro deflator growth, and non-debt inflows in percent of GDP) remain at their levels of the last projection year.

7/ Estimate. 
Table 15. Bulgaria: Public Sector Debt Sustainability Framework, 2001-2011

(In percent of GDP, unless otherwise indicated)

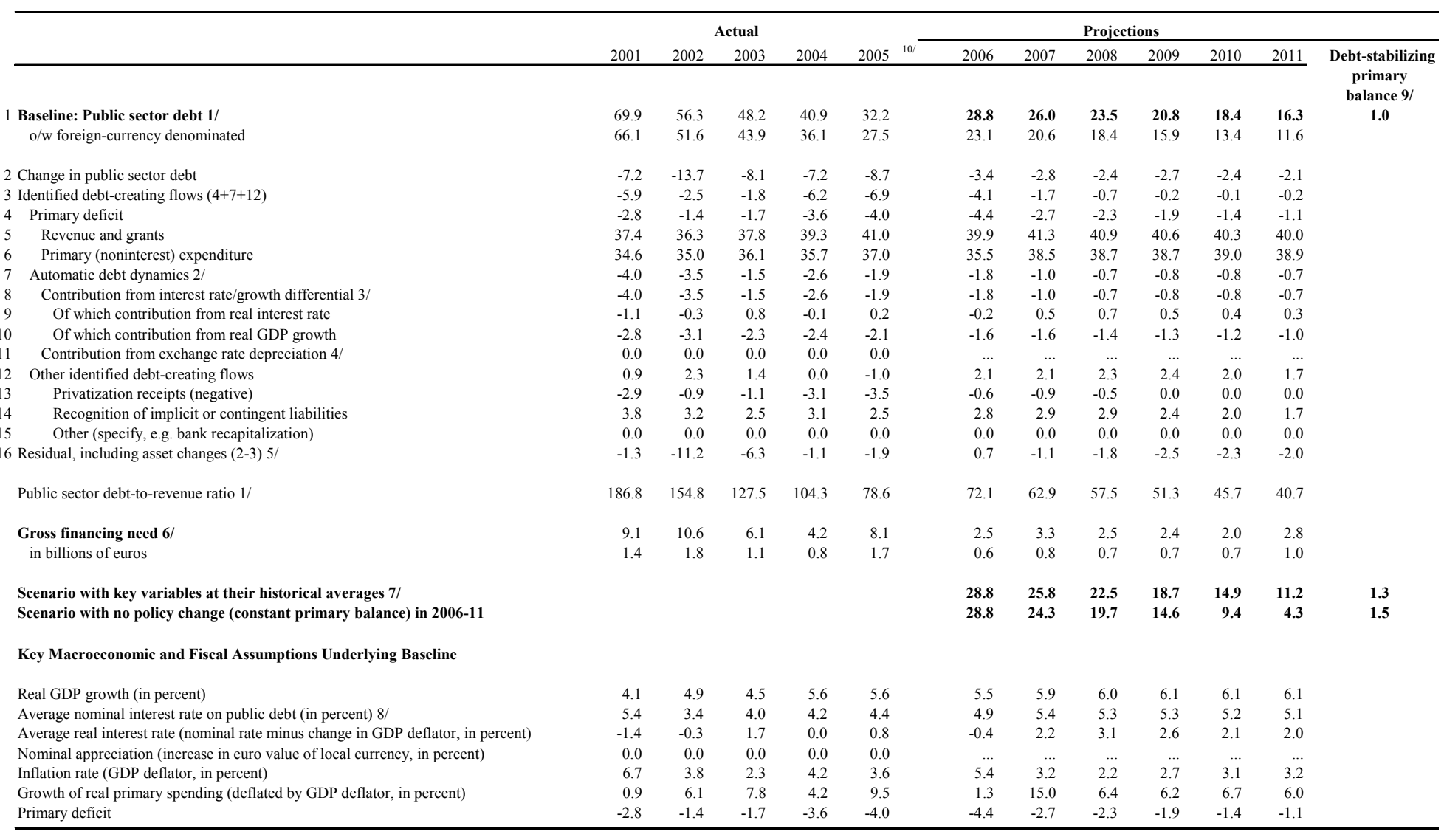

Sources: Bulgarian authorities; and Fund staff estimates.

1/ Indicate coverage of public sector, e.g., general government or nonfinancial public sector. Also whether net or gross debt is used.

2/ Derived as $[(\mathrm{r}-\pi(1+\mathrm{g})-\mathrm{g}+\alpha \varepsilon(1+\mathrm{r})](1+\mathrm{g}+\pi+\mathrm{g} \pi))$ times previous period debt ratio, with $\mathrm{r}=$ interest rate; $\pi=$ growth rate of GDP deflator; $\mathrm{g}=$ real GDP growth rate; $\alpha=$ share of foreign-currency

denominated debt; and $\varepsilon=$ nominal exchange rate depreciation (measured by increase in local currency value of euro).

$3 /$ The real interest rate contribution is derived from the denominator in footnote $2 /$ as $r-\pi(1+\mathrm{g})$ and the real growth contribution as $-\mathrm{g}$.

4/ The exchange rate contribution is derived from the numerator in footnote $2 /$ as $\alpha \varepsilon(1+\mathrm{r})$.

the rind

medium and long-term public sector debt, plus short-term debt at end of previous period.

7/ The key variables include seven year averages of real GDP growth, real interest rate, and primary balance in percent of GDP.

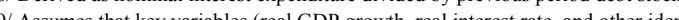

entified debt-creating flows) remain at the level of the last projection year.

10/ Estimate. 
Table 16. Bulgaria: Capacity to Repay the Fund, 2003-2011 1/

\begin{tabular}{|c|c|c|c|c|c|c|c|c|c|}
\hline & 2003 & 2004 & 2005 & 2006 & 2007 & 2008 & 2009 & 2010 & 2011 \\
\hline \multicolumn{10}{|l|}{ Fund repurchases and charges } \\
\hline In millions of SDRs 2/ & 90.4 & 110.5 & 325.4 & 233.8 & 113.2 & 88.8 & 92.5 & 70.5 & 17.1 \\
\hline In millions of euros & 112.2 & 131.4 & 386.0 & 282.7 & 136.7 & 107.0 & 111.2 & 84.6 & 20.4 \\
\hline In percent of exports of goods and NFS & 1.2 & 1.2 & 3.0 & 1.8 & 0.8 & 0.6 & 0.6 & 0.4 & 0.1 \\
\hline In percent of total debt service & 8.5 & 5.4 & 7.2 & 19.0 & 7.1 & 5.3 & 4.8 & 3.2 & 0.6 \\
\hline In percent of quota & 14.1 & 17.3 & 50.8 & 36.5 & 17.7 & 13.9 & 14.5 & 11.0 & 2.7 \\
\hline In percent of gross international reserves & 2.1 & 1.9 & 5.2 & 3.5 & 1.6 & 1.1 & 1.1 & 0.8 & 0.2 \\
\hline \multicolumn{10}{|l|}{ Fund credit outstanding } \\
\hline In millions of SDRs & 799.2 & 762.0 & 461.9 & 346.9 & 248.2 & 169.7 & 84.1 & 16.6 & 0.0 \\
\hline In millions of euros & 954.1 & 875.4 & 557.6 & 419.3 & 299.4 & 204.3 & 101.0 & 19.9 & 0.0 \\
\hline In percent of exports of goods and NFS & 10.1 & 7.7 & 4.3 & 2.7 & 1.7 & 1.1 & 0.5 & 0.1 & 0.0 \\
\hline In percent of quota & 124.8 & 119.0 & 72.1 & 54.2 & 38.8 & 26.5 & 13.1 & 2.6 & 0.0 \\
\hline In percent of gross international reserves & 17.7 & 12.8 & 7.6 & 5.3 & 3.4 & 2.1 & 1.0 & 0.2 & 0.0 \\
\hline \multicolumn{10}{|l|}{ Memorandum items: } \\
\hline Exports of goods and NFS (in millions of euros) & $9,458.7$ & $11,346.7$ & $13,040.8$ & $15,804.7$ & $17,336.6$ & $18,336.9$ & $19,892.1$ & $21,619.1$ & $23,878.5$ \\
\hline Debt service (in millions of euros) & $1,315.4$ & $2,428.5$ & $5,397.3$ & $1,484.6$ & $1,929.4$ & $2,028.2$ & $2,332.8$ & $2,660.3$ & $3,178.1$ \\
\hline Quota (in millions of SDRs) & 640.2 & 640.2 & 640.2 & 640.2 & 640.2 & 640.2 & 640.2 & 640.2 & 640.2 \\
\hline Quota (in millions of euros) & 764.3 & 735.5 & 772.9 & 773.9 & 772.4 & 770.5 & 769.0 & 767.3 & 765.4 \\
\hline Gross international reserves (in millions of euros) & $5,405.0$ & $6,854.2$ & $7,370.3$ & $7,974.9$ & $8,779.7$ & $9,519.8$ & $10,007.6$ & $10,568.5$ & $11,018.4$ \\
\hline Euros per SDR (period avg) & 1.24 & 1.19 & 1.19 & 1.21 & 1.21 & 1.20 & 1.20 & 1.20 & 1.20 \\
\hline Euros per SDR (eop) & 1.19 & 1.15 & 1.21 & 1.21 & 1.21 & 1.20 & 1.20 & 1.20 & 1.20 \\
\hline
\end{tabular}

$1 /$ Assumes purchases are made under the current precautionary arrangement.

2/ Projections are based on actual repurchases through end-February and obligations basis thereafter. 
Table 17. Bulgaria: Financial Relations with the Fund, 2000-2010

\begin{tabular}{|c|c|c|c|c|c|c|c|c|c|c|c|}
\hline & 2000 & 2001 & 2002 & 2003 & 2004 & 2005 & 2006 & 2007 & 2008 & 2009 & 2010 \\
\hline & \multicolumn{11}{|c|}{ (In millions of SDRs) } \\
\hline \multicolumn{12}{|l|}{ Purchases } \\
\hline SBA & 0.0 & 0.0 & 84.0 & 104.0 & 52.0 & 0.0 & 0.0 & 0.0 & 0.0 & 0.0 & 0.0 \\
\hline $\mathrm{EFF}$ & 209.2 & 104.6 & 0.0 & 0.0 & 0.0 & 0.0 & 0.0 & 0.0 & 0.0 & 0.0 & 0.0 \\
\hline \multicolumn{12}{|l|}{ Obligations schedule } \\
\hline Repurchases & 105.3 & 236.2 & 195.2 & 76.6 & 89.2 & 300.1 & 215.0 & 98.7 & 78.5 & 52.3 & 17.4 \\
\hline Charges and interest & 33.8 & 36.7 & 18.1 & 13.8 & 21.3 & 25.3 & 16.0 & 9.9 & 5.8 & 2.5 & 0.5 \\
\hline Fund credit outstanding & $1,014.6$ & 883.0 & 771.8 & 799.2 & 762.0 & 461.8 & 246.9 & 148.2 & 69.7 & 17.4 & 0.0 \\
\hline \multicolumn{12}{|l|}{ Expectations schedule } \\
\hline Repurchases & 105.3 & 236.2 & 195.2 & 76.6 & 89.2 & 300.1 & 235.2 & 78.5 & 78.5 & 52.3 & 17.4 \\
\hline Charges and interest & 33.8 & 36.7 & 18.1 & 13.8 & 21.3 & 25.3 & 15.5 & 9.4 & 5.8 & 2.5 & 0.5 \\
\hline Fund credit outstanding & $1,014.6$ & 883.0 & 771.8 & 799.2 & 762.0 & 461.8 & 226.6 & 148.2 & 69.7 & 17.4 & 0.0 \\
\hline
\end{tabular}

Source: Fund staff calculations. 


\section{BULGARIA: FUND RELATIONS}

As of January 31, 2006

I. Membership Status: Joined 09/25/1990; Accepted Article VIII 09/24/1998

II. General Resources Account:

Quota

Fund holdings of currency

Reserve position in Fund

III. SDR Department:

Holdings

IV. Outstanding Purchases and Loans:

Stand-by Arrangements

Extended Arrangements

V. Financial Arrangements:

$\begin{array}{lcccc}\begin{array}{l}\text { Type } \\ \text { Stand-by }\end{array} & \begin{array}{c}\text { Approval } \\ \text { date }\end{array} & \begin{array}{c}\text { Expiration } \\ \text { date }\end{array} & \begin{array}{c}\text { Amount approved } \\ \text { (SDR million) }\end{array} & \begin{array}{c}\text { Amount drawn } \\ \text { (SDR million) }\end{array} \\ \text { Stand-by } & 08 / 06 / 2004 & 09 / 05 / 2006 & 100.00 & 0.00 \\ \text { EFF } & 02 / 27 / 2002 & 03 / 15 / 2004 & 240.00 & 240.00 \\ & 09 / 25 / 1998 & 09 / 24 / 2001 & 627.62 & 627.62\end{array}$

VI. Projected Payments to Fund (SDR million; based on existing use of resources and present holdings of SDRs): ${ }^{9}$

Principal

Charges/Interest

Total

$$
\begin{array}{r}
\text { SDR million } \\
640.20 \\
1,059.31
\end{array}
$$

33.00

$\underline{\text { SDR million }}$

7.0

$\underline{\text { SDR million }}$

305.08

147.00
\%Quota

100.00

165.46

5.15

\%Allocation

N/A

\%Quota

47.65

22.96

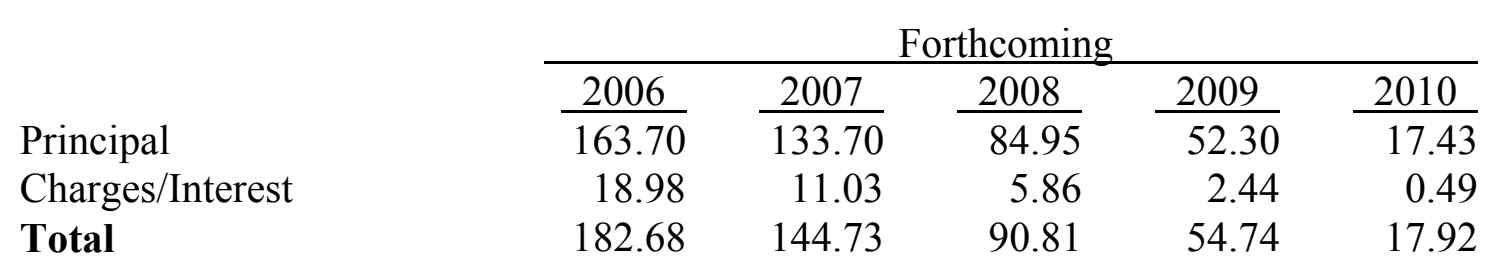

${ }^{9}$ On expectation basis. 


\section{Safeguards Assessment:}

Under the Fund's safeguards assessment policy, the Bulgarian National Bank (BNB) was subject to an assessment with respect to the SBA which was approved on February 27, 2002. The assessment, which was completed on June 12, 2002, identified certain weaknesses and made appropriate recommendations, as reported in IMF Country Report No. 02/174. An updated assessment, which was conducted with respect to the current SBA and completed on November 23,2004 , found that the BNB's financial statements had been improved and earlier audit qualifications eliminated, the scope of the internal audit function had been widened and a riskbased audit methodology had been introduced. No major vulnerabilities in the safeguards framework were identified. The mission's recommendations to further solidify Bulgaria's safeguards are being implemented.

\section{Exchange Arrangement:}

An amendment to the Law on the Bulgarian National Bank (BNB) effectively established a currency board arrangement from July 1, 1997. The deutsche mark was chosen at par as the peg currency, which has since been replaced with the euro at the rate of lev 1.95583 per $€ 1$. The $\mathrm{BNB}$ is buying and selling euros in noncash transactions at the parity rate. In cash transactions it levies a commission of 0.5 percent on the selling side. Bulgaria has accepted the obligations of Article VIII, Sections 2, 3, and 4 of the Articles of Agreement, and maintains an exchange system that is free of restrictions on the making of payments and transfers for current international transactions, except for those imposed in compliance with applicable UN Security Council resolutions. All such restrictions have been notified to the Fund pursuant to Decision No. $144(52 / 51)$.

\section{Article IV Consultation:}

The last Article IV consultation was concluded on June 14, 2004 (see IMF Country Report No. 04/176). Bulgaria is on a 24-month cycle. The Acting Chairman's summing-up of the discussion was circulated as SUR/04/60.

\section{FSAP Participation and ROSCs:}

Bulgaria participated in an FSAP held from October 29 to November 14, 2001. A follow-up to the FSAP update was conducted as part of the 2004 Article IV consultation mission. Table 18 provides information on the production of ROSCs.

\section{Technical Assistance}

Table 19 provides information on IMF technical assistance activities since 1999. 
Table 18. Bulgaria: ROSCs

Standard/code assessed
ROSC - Fiscal transparency module
ROSC - Detailed assessments using the data quality assessment
framework

framework

ROSC update - Data dissemination and fiscal transparency.

ROSC - Monetary and financial policy transparency, banking supervision, securities regulation, insurance regulation, and payment systems

ROSC update - Data dissemination, fiscal transparency, transparency of monetary and financial policies, banking supervision, deposit insurance, insurance supervision, securities market supervision

ROSC - Data dissemination, fiscal transparency, transparency of monetary policy, banking supervision, system of deposit insurance, insurance supervision, securities market supervision

Experimental ROSC - Data transparency, fiscal transparency, transparency of monetary policy, banking supervision, system of deposit insurance, insurance supervision, securities market supervision, insurance supervision, accounting and auditing practices

\begin{tabular}{ll}
$\begin{array}{l}\text { Date of } \\
\text { issuance }\end{array}$ & $\begin{array}{l}\text { Document } \\
\text { number }\end{array}$ \\
\hline
\end{tabular}

$08 / 05 / 2005$

IMF Country

Report

No. 05/300

$12 / 12 / 2003$

IMF Country

Report

No. 03/393

08/07/2002

IMF Country

Report

No. 02/172

07/15/2002

IMF Country

Report

No. 02/188

03/08/2001

www.imf.org

03/17/2000

www.imf.org

08/27/1999

www.imf.org

\section{Resident Representative:}

Mr. James Roaf took up the resident representative position on August 24, 2003. 
Table 19. Bulgaria: Technical Assistance, 1999-2006

\begin{tabular}{|c|c|c|c|c|}
\hline Dept. & Subject/Identified Need & Action & Timing & Counterpart \\
\hline MAE & Accounting & Expert & Jun. \& Aug./Sep.99 & $\mathrm{BNB}$ \\
\hline MAE & Transparency Report/Based Core Principles & Mission & Jul. 99 & $\mathrm{BNB}$ \\
\hline MAE & Deposit insurance & Mission & Oct. 99 & BNB \\
\hline MAE & Accounting & Expert & Feb. 00 & BNB \\
\hline MAE & $\begin{array}{l}\text { Payment system/liquidity management/ } \\
\text { bankruptcy legislation }\end{array}$ & Mission & May 00 & BNB \\
\hline MAE & Bankruptcy legislation & Expert & Jun. 00 & BNB \\
\hline MAE & Foreign exchange & Mission & Nov. 00 & $\mathrm{BNB}$ \\
\hline MAE & Accounting & Expert & Nov.-Dec. 00 & BNB \\
\hline MAE & Short-term advisor payment system & Expert & Jun. 01 & BNB \\
\hline MAE & Accounting and Internal Audit & Expert & Apr. 02 & BNB \\
\hline MAE & Foreign Exchange & Expert & Apr. 02 & BNB \\
\hline MAE & Review of TA needs resulting from FSAP & Mission & May 02 & BNB \\
\hline MAE & Accounting & Expert & Aug. 02 & $\mathrm{BNB}$ \\
\hline MAE & Accounting & Expert & Oct. 02 & $\mathrm{BNB}$ \\
\hline MAE & Accounting & Expert & Mar.-Apr. 03 & $\mathrm{BNB}$ \\
\hline MFD & Accounting & Expert & Oct. 03 & $\mathrm{BNB}$ \\
\hline MFD & Accounting & Expert & Oct. 04 & BNB \\
\hline MFD & Policies and tools to manage rapid credit growth & Mission & Dec. 04 & BNB \\
\hline MFD & Financial Accounting and Information Systems & Mission & Apr. 05 & $\mathrm{BNB}$ \\
\hline MFD & Accounting and internal audit & Expert & Oct. 05 & BNB \\
\hline MFD & Financial Management Systems Implementation & Expert & Jan.-Feb. 06 & BNB \\
\hline FAD & Budget General & Expert & Jun. 99 & MOF \\
\hline FAD & Tax administration & Expert & Jul. 99 & MOF \\
\hline FAD & Public Expenditure Management & Mission & Sep. 99 & MOF \\
\hline FAD & Budget General & Expert & Oct. $99-$ Oct. 00 & MOF \\
\hline FAD & Tax Administration & Mission & Jan. 00-Feb. 00 & MOF \\
\hline FAD & Tax Administration Advisor & Expert & Apr.-Jun. 00 & MOF \\
\hline FAD & Tax Administration & Expert & Apr.-May 00 & MOF \\
\hline FAD & Tax Administration & Expert & May-Jun. 00 & MOF \\
\hline FAD & Tax Administration & Expert & Jun. 00 & MOF \\
\hline FAD & Tax Administration & Expert & Sep. 00-01 & MOF \\
\hline FAD & Expert Installation mission/Tax Administration & Expert & Oct. 00 & MOF \\
\hline FAD & Tax Administration-Follow-up Mission & Mission & Jan. 01 & MOF \\
\hline FAD & Public Expenditure Management & Mission & Jan.-Feb. 01 & MOF \\
\hline FAD & Mission for Workshop & Mission & Jun. 01 & MOF \\
\hline FAD & Tax Administration Follow-up Mission & Expert & Sep. 01 & MOF \\
\hline FAD & Customs administration & Mission & Oct. 01 & MOF \\
\hline FAD & Tax policy & Mission & Jan. 02 & MOF \\
\hline FAD & Budget General & Expert & Apr. 02-Mar. 03 & MOF \\
\hline FAD & TA Expert Installation Mission & Expert & Apr. 02 & MOF \\
\hline FAD & Tax Administration Follow-Uup Mission & Mission & Apr. 02 & MOF \\
\hline FAD & Tax Administration & Expert & Sep.-Oct. 02 & MOF \\
\hline FAD & Budget General: Inspection & Expert & Jan. 03 & MOF \\
\hline FAD & Tax Administration-Installation Visit & Expert & Mar.03 & MOF \\
\hline FAD & Tax Administration & Expert & Mar.-Apr. 03 & MOF \\
\hline FAD & Public Expenditure Management & Expert & Apr-Sep. 03 & MOF \\
\hline FAD & Tax Administration & Mission & Apr. 04-May. 04 & MOF \\
\hline FAD & Accrual Accounting and Budget Execution Reforms & Mission & Sep. 05 & MOF \\
\hline FAD & Program Budgeting & Expert 1/ & Sep. 05 & MOF \\
\hline STA & BOP statistics & Mission & Jun.-Jul. 99 & BNB \\
\hline STA & GDDS & Mission & Jul. 99 & BNB \\
\hline STA & National accounts & Mission & Nov. 99 & NSI \\
\hline STA & Price statistics & Mission & Jun. 00 & NSI \\
\hline STA & BOP statistics & Mission & Dec. 00 & BNB \\
\hline STA & Producer prices & Mission & Nov. 01 & NSI \\
\hline STA & Producer prices & Mission & Apr. 02 & NSI \\
\hline STA & Price statistics & Mission & May 02 & NSI \\
\hline STA & Producer prices & Mission & Jan 03 & NSI \\
\hline STA & Data ROSC & Mission & Jan.03 & $\mathrm{BNB} / \mathrm{MOF} / \mathrm{NSI}$ \\
\hline STA & SDDS & Mission & Sep. 03 & BNB \\
\hline STA & Producer prices & Mission & Sep. 04 & NSI \\
\hline
\end{tabular}

1/ Mission by FAD's Regional TA Advisor based in Slovenia. 


\section{Bulgaria: IMF-World Bank Relations}

\section{A. Partnership in Bulgaria's Development Strategy}

1. The government's economic program has been underpinned by a conservative fiscal policy and significant progress with structural reforms. So far Bulgaria has made substantial progress towards long-term macroeconomic stability - an important step along the way to its ultimate goals of improving living standards and accession to the EU. The wide-ranging reforms in the government's agenda hinge on the continuing challenge of macroeconomic stability in the context of the Currency Board Arrangement (CBA), sustaining structural reforms and establishing a business environment conducive to growth, together with improved governance, a deeper financial system, and investment in human capital and physical infrastructure.

2. The IMF has been leading in supporting Bulgaria's medium-term program in maintaining macroeconomic stability. Building on the achievements of the three-year Extended Fund Facility (EFF) arrangement with Bulgaria, in February 2002 the IMF Board approved a two-year StandBy Arrangement (SBA) with Bulgaria. The SBA, with a reduced scope and detail of structural conditionality compared to the EFF, focused on medium-term fiscal challenges and structural reforms with significant macroeconomic, typically fiscal, implications. In August 2004, the IMF Board approved a 25-month precautionary SBA (ending September 2006) in an amount of SDR100 million.

3. The World Bank has been leading the policy dialogue in structural and institutional reforms aiming at (i) promoting competitive private sector-led growth; (ii) strengthening market institutions and improving both corporate and public sector governance; and (iii) mitigating the social impact of restructuring and delivering social services more effectively. In May 2002 the Board of Directors discussed the Country Assistance Strategy (CAS) of the Bank which outlined the roadmap for the Bank's country support for the period 2002-04. In addition to the Bank's ongoing lending operations in areas such as health, child welfare, water, trade and transport, environment, land registration and cadastre, the CAS included a three-year programmatic adjustment lending (PAL) program of up to three PALs of up to US\$150 million each. In February 2003, the Board of Directors approved the first PAL operation - it aimed at advancing structural, regulatory, and institutional reforms in the real and financial sectors. In June 2004, the Board of Directors approved the second PAL (PAL-2), which aimed at supporting improvements in public sector governance. The third PAL (PAL-3) was approved by the Board of Directors in June 2005. The Bank continues to undertake substantive country diagnostics providing a solid base for policy dialogue and design and implementation of its lending operations in Bulgaria.

\section{B. IMF-World Bank Collaboration in Specific Areas}

4. In general, the Bank has the lead on the dialogue on the core structural aspects of the reforms while the Fund has the lead on the dialogue on the macroeconomic, typically fiscal, aspects of the reforms. There are a number of areas where the IMF leads and its analyses serve as inputs into World Bank policy formulation and advice, including policies to maintain macroeconomic stability, fiscal policies, income policies and external sector policies. There are 
other areas in which the Bank and the Fund share responsibility and are coordinating closely their policy advice to the Bulgarian authorities such as in the financial sector, public expenditure management and budgeting, and tax administration. In some areas, the Bank has taken the lead but its analysis, country diagnostic work, and policy recommendations served as inputs into the Fund's policy advice on the fiscal front such as education, health care, pensions, social protection, energy, and railways. In areas such as private sector development, strengthening market institutions (including entry and exit policies, regulatory reform to enhance the business climate, judicial reform, labor market reform), and improving governance the Bank has the lead and there has been little conditionality under Fund programs. In addition to consultations early in the process of formulating and adjusting each institution's program with Bulgaria, the Bank and Fund staff teams interact extensively during the review of the progress achieved in the country and coordinate closely their policy advice to the Bulgarian authorities.

\section{B.1. Areas where the IMF leads and its analyses serve as inputs into the World Bank policy formulation and advice.}

5. To achieve the objectives of their economic program, the Bulgarian authorities are fully committed to maintain sound and flexible macroeconomic policies centered on a Currency Board Arrangement (CBA) and implement an ambitious reform agenda. In particular, the authorities have maintained a tight fiscal policy since 1998, attaining a surplus of 2.4 percent of GDP in 2005 . The aim is to have three percent surplus in 2005 , conduct fiscal policy flexibly in the face of shocks, and maintain a high level of fiscal reserve assets. Given the constraints of the CBA, the authorities see labor market policies as another key component of the broad policy strategy. A strict incomes policy for the state enterprise sector is enforced and measures aimed at facilitating the adjustment of labor markets are being implemented. The structural and institutional reforms, which constitute the third pillar of the policy strategy, are focused on creating a fully functioning market economy that is competitive and can flexibly adjust to shocks.

6. In the context of a 25-month Stand-By Arrangement that was approved in August 2004, the IMF continued to lead in assisting Bulgaria in safeguarding macroeconomic stability and promoting structural reforms in areas that are macro-critical and fall within the Fund's core expertise. To safeguard the CBA and ensure that it can continue to serve as the macroeconomic policy anchor, the IMF set a floor on the size of the overall surplus of the general government and a ceiling on central government arrears. To prevent threats to the currency board and macroeconomic stability that could arise from a loss in competitiveness or excessive external financing requirements, Fund conditionality also included ceilings on the wage bill of those state enterprises that have the largest losses and arrears, are monopolies, and receive subsidies, and on the contracting and guaranteeing of public sector external debt. 


\section{B.2. Areas of shared responsibility.}

7. Financial Sector. In late 2001, staff of the two institutions carried out a joint IMF-World Bank Financial Sector Assessment Program (FSAP) for Bulgaria, providing a shared perspective on the development agenda of the country and on the prioritization and sequencing of reforms in the financial sector. Key findings of the FSAP are conditionalities on financial sector policies under both the SBA and the PAL program. The IMF has emphasized aspects related to the banking sector - mainly on policies under the mandate of BNB and supervisory agencies - while the World Bank is focusing on policies that affect market performance and development of the financial sector such as improving the legal and institutional framework for lending, restructuring of the banking sector, strengthening creditor rights, corporate insolvency and governance, and non-banking financial sector issues. A follow-up to the FSAP was undertaken by Fund staff in the context of the 2004 Article IV consultation mission in March-April 2004.

8. Since 1997, in the context of two Finance and Enterprise Adjustment Loans (FESALs), and with the PAL program, the Bank has supported the government in sector restructuring of the financial sector. Privatization of commercial banks was a major component of the FESALs, while the Fund provided support for the institution building efforts of the BNB and its Banking Supervision Department in particular. In the financial sector, the Bank focused on banking, insurance, pension funds, and capital markets while the Fund continued its focus on the BNB, banking supervision, and the payments system.

9. Revenue Administration. The IMF and the World Bank have been carrying out a joint effort since 1996 to assist Bulgaria in reforms aimed at the establishment of an efficient revenue collection agency. Diagnostics consistently pointed to revenue collection deficiencies including weak management, and problematic audit and enforcement of collection, which in turn facilitates low compliance. Supporting reform efforts, the World Bank implemented a project to modernize the Social Security Institute, including its revenue collection activities. The IMF provided a long-term advisor to the Ministry of Finance, and focused advisory services through consulting assignments. Joint World Bank-IMF efforts resulted in a proposal for "Implementing a Modern Revenue Collection Agency" in March 2000, which is moving forward. The World Bank's Board approved on June 5, 2003 the Revenue Administration Reform Project (RARP, €31.9 million), developed with technical assistance of the IMF, to support the establishment of the national revenue agency (NRA), which seeks to maximize the level of voluntary taxpayer compliance, promote effectiveness and efficiency, establish a professional workforce and approach to collection, and help reduce the scope for corruption.

10. Public Expenditure Management. The Bank has taken the lead in the dialogue on the efficiency and effectiveness of public expenditures and has outlined policy directions in the 
context of the Public Expenditure and Institutional Review (PEIR) ${ }^{10}$ of 2002, and the recently completed Public Finance Policy Review.

11. The IMF has provided long-term technical assistance on budgeting and expenditure management. To ensure the fiscal discipline necessary to support the CBA, the government has initiated a number of public expenditure management reforms. New budget procedures were introduced in early 2002 and were implemented for the 2003 budget. Despite this important progress, there is a need to continue and broaden the reform effort-capital expenditure proposals should be prepared under hard budget constraints and as an integral part of the medium-term budget frameworks; and the financial management at the local level should be strengthened.

\section{B.3. Areas where the World Bank leads and its analyses serve as inputs into the IMF policy formulation and advice.}

12. Energy sector. The Bank has played the lead role in assisting the government in the design of the reform program in the sector, and more importantly in its implementation. After the completion of the Energy Project at end-2000, the Bank has continued to support the developmental objectives of the sector to increase the energy efficiency. Under the PAL program, the government strengthened the legal and regulatory framework, removed major price distortions and initiated steps to enable the private sector to assume an increasing share of commercial risks. Policy recommendations were outlined in the Bank Energy and Environment Review completed in 2002, which aimed at also evaluating alternative strategies to balance the need for economic development and environmental protection. In June 2003 the Bank's Board approved two district heating projects to support the rehabilitation of the Sofia and the Pernik District Heating Companies. The Fund's and the Bank's teams have worked collaboratively in close consultations with the government, and the previous SBA included a performance criterion focusing on implementation of the schedule for bringing electricity prices to full cost recovery level, and two benchmarks - one on implementation of the new regulatory pricing regime, and the other on preparing a new Energy Act to harmonize Bulgaria's legislation with EU Directives.

13. Railways. The Bank has been the government's main external partner in the transformation of the railway sector, particularly through the Railway Rehabilitation Project, which was completed in June 2002. This transformation is at present only half way achieved. Some essential measures were implemented under the PAL program, especially the divestiture of all railway ancillary activities, securing a major staffing optimization, signing a Public Service Contract, and completing the institutional separation of the national company into two new infrastructure and rail services enterprises together with the opening of rail services to private operators. Key remaining steps include completion of the tariff reform, further staff

${ }^{10}$ The PEIR is entitled Bulgaria: Public Expenditure Issues and Directions for Reform, August 2002, The World Bank, (Report No. 23979-BUL) 
optimization, and improved corporate governance. They were supported by the Bank through the PALs.

14. Education. The reform efforts in the education sector aim at improving expenditure management in view of the declining population, especially in school age, and at enhancing quality and access to education. The main priority in the education sector, including universities, is to reallocate expenditures from surplus capacity in teaching staff and underused facilities toward modernization and upgrading of curricula, textbooks, teaching materials, schools, and other quality-enhancing education inputs. The Bank has supported the government program in education through the Education Modernization Project loan (closed on March 31, 2004), the PALs, and the analytical work done for the Poverty Assessment, the PEIR, the Intergovernmental Finance study ${ }^{11}$, and the Public Finance Policy Review. Under PAL-2 the government developed a concept for an education reform strategy and action plan, the implementation of which was supported through PAL-3.

15. Health care. Key reform priorities in the health sector include addressing the concurrent problems of surplus capacity issues in health facilities and hospitals, the serious deterioration in the quality of facilities and health services, and the inadequate modernization of equipment. At the same time, the government needs to ensure the financial integrity of the NHIF, which is the central point of the reforms in the sector. The Bank supported the restructuring of the health sector through the Health Sector Restructuring Project which was closed at end-2001. The follow-up Health Sector Reform project approved in late 2000 is under implementation and focuses on the administrative and information systems of the NHIF, and supports the ambulatory care sector and the hospital sector. The reform agenda was also supported through the PALs, with PAL-3 focusing on the implementation of the action plan for the hospital restructuring.

16. Social protection programs. Social protection programs - pensions, labor market programs, social assistance, and short-term and family benefits - have a wide coverage among the population. On pensions, one reform priority is to improve compliance with, and coverage of, the public pillar. Ensuring successful implementation of the pension reform was supported through the PALs. On labor market programs, there is a need to monitor these closely to improve their effectiveness and long-term impact in stimulating labor demand. Subject to progress in key reforms, consideration should be given to reduce the tax burden related to labor market policies in order to curtail labor costs. ${ }^{12}$ Some social assistance and benefit programs have become more pro-poor since the mid-1990s and are playing a major role in alleviating poverty. However, given the plethora of these programs, and the complexity of program design in many cases, a

${ }^{11}$ Issues in Intergovernmental Relations, the World Bank, January 27, 2004, Report No. 25821-BUL.

${ }^{12}$ However, such fiscal adjustment requires increasing efficiency in public expenditures, and lowering public expenditures to GDP before implementing tax reductions. 
constant challenge of the social protection system as a whole is to consolidate the system driven by improving targeting of vulnerable groups, and engage in systematic monitoring of the programs, their costs and effectiveness to ensure fiscal sustainability.

17. The Bank has been the main partner of the government in its efforts to address poverty reduction and meet its social development objectives. The main findings of the Poverty Assessment contributes significantly to the enhanced policy dialogue with the government on its policy options to improve living standards in the country, and increase the effectiveness and adequacy of its social protection programs. The Bank is assisting these important reforms in the social protection system through providing grants amounting to US\$2.2 million. The latter focus on poverty monitoring and evaluation, integration of ethnic minorities, child development and building social capital in disadvantaged communities. A Bank-financed Child Welfare Reform project helps address the needs of children in public care, while a Bank-financed Social Investment and Employment Promotion (SIEP), which supports community and employment creation and strengthening of ALMPs, was approved in 2002. The IMF has been also monitoring the sustainability of the pension system and the advancing of the labor market reforms in terms of their relevance for the Fund's program objectives.

\section{B.4. Areas where the World Bank leads and there is no direct IMF involvement.}

18. Private Sector Development. Bulgaria has completed the divestiture of about 95 percent (based on value of assets) of its non-infrastructure state-owned enterprises (SOEs) since 1995. To encourage the entry of new firms and the expansion of existing ones, the business climate will have to continue to improve focusing on reducing barriers to entry, reducing compliance cost of the regulatory regime, developing a competitive environment, and establishing an efficient exit mechanism for non-viable enterprises. Under the PAL program, major changes in the basic legislation were initiated - notably the Commercial Code, the Civil Procedure Code, and the Labor Code, and the passage of legislation on how the State will regulate economic activity to ensure stability and predictability of regulatory regimes.

\section{In the context of the two Finance and Enterprise Adjustment Loans (FESALs) and} the PAL program, the Bank supported the government in sector restructuring of the noninfrastructure enterprise sector. Privatization of SOEs was a major component of the FESALs. Under the PALs, the Bank led the dialogue on reforms covering the regulatory regimes, the insolvency process, and competition.

20. Public sector governance. The government is pursuing a broad program to improve public sector governance including strengthening the capacity of the public administration, improving service delivery, reducing corruption, and reforming the judiciary. The support of this program was the main focus of PAL-2. The policy, legal and institutional framework was developed and put in place to strengthen merit and depolitization. Performance standards for service delivery were developed and one-stop shop principles were introduced in five central administrations and six regional administrations. The system of performance appraisal and professional development within the state administration were enhanced. Concrete steps were undertaken to increase accountability and transparency - the conflict of interest and asset declaration regime was strengthened; a monitoring system to track progress in meeting the anti- 
corruption objectives was designed; key ministries and agencies prepared detailed and practical anticorruption action plans.

\section{The World Bank Group Strategy and Lending Operations}

21. The Country Assistance Strategy (CAS) for Bulgaria ${ }^{13}$, discussed by the Bank's Board on May 9, 2002, focused on three main themes: (i) promotion of competitive private sector led growth, (ii) strengthening public administration reforms and anti-corruption initiatives, and (iii) mitigating the social impact of restructuring and delivering social services more effectively. A new Country Partnership Strategy (CPS) is scheduled to be prepared in the spring of 2006.

22. Programmatic Adjustment Lending. Three Programmatic Adjustment Loans (PALs), have been approved by the Board: the first one--PAL-1--in February 2003, PAL-2 in June 2004, and PAL-3 in June 2005. The PAL program has supported the government's reforms aiming at: (a) completion of privatization and restructuring in energy and infrastructure; (b) improving the environment for private sector led growth; (c) deepening the financial sector; (d) reducing poverty and improving human capital, and better delivery of social services; and (e) support public administration reform and anti-corruption programs.

23. The World Bank's assistance program in Bulgaria to date comprises 38 operations for a total original commitment of US\$2,137.2 million equivalent. This includes 12 adjustment loans (US\$1,225.8 million), 19 investment projects (US\$750.7 million), one debt reduction loan (US\$125.0 million), four Bank-managed Global Environmental Fund (GEF) grants, and two Bank-managed Prototype Carbon Fund (PCF) operations. Of these 38 operations, 25 have been completed, of which ten have been partially cancelled during implementation, and 12 operations are currently under implementation (see Table 1 below).

24. IFC's Activities in Bulgaria comprise 28 projects (totaling \$385 million) in the support of financial sector development, oil and gas, food and beverages, retail, tourism and restructuring of post-privatized companies. Of those, 24 projects were approved from fiscal year 1999-on. In the financial sector, IFC has supported two specialized SME banks, established Bulgaria's first micro lending bank, and has invested in a leasing company and in a venture capital fund. Also, IFC has invested in a number of key manufacturing projects covering cement production, electronic assembly, pulp and paper mill, and copper processing. In FY05, IFC invested $\$ 69$ million in new commitments to support a project in retail and extended a credit line to a local bank for on-lending to SMEs, whereas in FY04, IFC has committed about $\$ 102$ million to support post-privatization restructuring of a steel mill and glass processing plants.

\footnotetext{
$13{ }^{1}$ Memorandum of the President of the International Bank for Reconstruction and Development and the International Finance Corporation to the Executive Directors on a Country Assistance Strategy of the World Bank Group for Bulgaria, May 31, 2002.
} 
25. Economic and Sector Work. The country diagnostic work recently completed includes: Country Financial Accountability Assessment, Survey on Rural Development Needs, Issues in Inter-governmental Relations, Environmental Sequencing Strategies for EU Accession, and the National Energy Efficiency Study. Other country diagnostic work being completed includes an infrastructure and energy study, and a roads study, and a Country Economic Memorandum focused on policy reforms for growth and successful EU integration. Also, a Public Finance and Policy Review, which examines the options for programming of EU Structural Funds in a fiscally responsible manner, has recently been finalized.

Table 20. Bulgaria: Active World Bank Operations (net of cancellations) ${ }^{\text {a/ }}$

\begin{tabular}{llcc}
\hline & Operation & US \$ million & $\begin{array}{c}\text { Board } \\
\text { Date }\end{array}$ \\
\hline 1. & Health Sector Reform & 63.3 & 2000 \\
2. & Child Welfare Reform & 8.0 & 2001 \\
3. & Registration and Cadastre & 30.0 & 2001 \\
4. & Wetlands Restoration and Pollution Reduction (GEF Grant) & 7.5 & 2002 \\
5. & Social Investment and Employment Promotion & 50.0 & 2002 \\
6. & Revenue Administration Reform Project & 34.2 & 2003 \\
7. & District Heating Project & 34.2 & 2003 \\
8. & Wood Residue to Energy (PCF) & 1.8 & 2003 \\
9. & District Heating (PCF) & 5.0 & 2004 \\
10. & Energy Efficiency Fund (GEF) & 10.0 & 2005 \\
11. & Pomoriisko Lake (GEF) & 0.9 & 2005 \\
12. & Programmatic Adjustment Loan 3 b/ & 150.0 & 2005 \\
\hline
\end{tabular}

Notes: $a$ / PAL-1 (US\$ 150 million) was approved by the Board on February 20, 2003, PAL-2 (equivalent to US\$125 million) was approved by the Board on June 10, 2004. b/ Not effective yet.

Questions may be referred to Ms. Myla Taylor Williams (202-473-6997), Ms. Satu Kähkönen (202-473-2170), or Ms. Stella Ilieva (202-473-1744). 


\section{Bulgaria: Statistical Issues}

1. Bulgaria compiles and submits data to the Fund of sufficient quality and in a timely manner to adequately permit program monitoring and surveillance. Despite a comprehensive economic database, problems remain in national accounts and price statistics, particularly in the coverage of the emerging private sector, as well as in the balance of payments statistics, where frequent and substantial revisions have hampered economic analysis. In addition, work remains to be done in fully reconciling high frequency data on economic activity with quarterly and annual national accounts data. Annual international investment position statistics are compiled and reported to STA for publication.

2. In January 2003, an STA mission visited Bulgaria to produce a data module of the Report on the Observance of Standards and Codes (ROSC). The report provided a summary of Bulgaria's data dissemination practices against the Fund's Special Data Dissemination Standard, even though Bulgaria has worked with the General Data Dissemination System (GDDS). In late 2003, Bulgaria moved from participation in the GDDS to SDDS subscription, marking a major step forward in the development of the country's statistical system.

\section{Real sector}

3. The National Statistical Institute (NSI), with technical assistance from the OECD, has established a system to compile national accounts according to the recommendations of the European System of Accounts 1995. GDP data by activity and expenditure categories are compiled and reconciled within an annual supply and use framework. Government output and final consumption are estimated on a cash rather than an accrual basis. In addition, Bulgaria publishes national accounts including current and capital accounts for the five main domestic sectors (general government, financial corporations, nonfinancial corporations, nonprofit institutions serving households, and households). As for most countries, the financial account and the balance sheets are missing.

4. The NSI has compiled estimates of quarterly GDP by the production and expenditure approaches in current and constant prices since 1994. The preliminary data are disseminated 80 days after the end of the reference quarter with final figures disseminated after approximately 5 quarters. Problems remain in the coverage of private sector activities as well as on the constant price estimates of capital formation and external trade. However, significant progress has been made in the development of export and import deflators. The estimates at constant prices use chain-linked indices, which follow international standards (SNA 1993).

5. A continuing producer price index (PPI) project covering the period June 2000 to January 2004 was established by a price statistics mission that visited the NSI in June 2000. The project included three supporting IMF technical assistance missions. The main objectives of the project were to convert from using average prices (unit values) for product categories to samples of transaction prices for fully specified products, and to update the index 
aggregation weights from 1995 to 2000 . Despite some minor slippage in timing due to unforeseen complexities, the project, which related to the domestic market, has now been completed. The major achievements include the completion of the progressive conversion to transaction pricing, rebasing the index to the year 2000, recommencement of publication (accompanied by notification in the Advance Release Calendar and Catalog of Publications and the release of up-to-date metadata), and improvement in the timeliness of release to conform to the SDDS standard. A revision of the producer price index (PPI) for domestic sales was completed in June 2004. The NSI has expanded the collection of transaction prices throughout the industrial sector of the domestic economy. Publication of the rebased PPI began in March 2003, with the weights and reference period updated to 2000 and linked at December 2002 to form a continuous monthly series for the period January 2000 to January 2003. The index is to be rebased every 5 years. Timeliness of release is now within one month. Also, progress is being made on the development of a PPI for export sales.

6. The consumer price index (CPI) provides a reasonable measure of inflation and price developments in Bulgaria. The recommendations provided by STA missions have been broadly implemented. The NSI has completed the exercise to link annual Laspeyres price indices together, producing a time series that begins in 1995. This series also follows the new classifications and index methods recommended by Eurostat and STA, and has been published as the official CPI. The coverage of the index was extended, although it still excludes some important sectors, mainly owner-occupied housing and health and life insurance. Since 2004 financial services are included. The geographical coverage of the index is restricted to 27 urban areas which account for an estimated 65 percent of sales. A new method for imputing missing observations of new products is being applied, but quality adjustment procedures are only applied in a few particular cases (e.g., the heating component).

7. The flow of customs data has improved significantly in recent years and a new system for processing customs records is near completion. The development of export and import unit value indices is progressing smoothly and additional support is expected from Eurostat in this area. The current indices can be used effectively as deflators for the import and export components of the national accounts. The Import and Export Division of the NSI meets monthly with the Bulgarian National Bank to review data issues and ensure consistency between the NSI export and import data and the balance of payments data.

8. The lack of comprehensive labor statistics has hampered the assessment of developments in employment and wages, especially in the private sector, though there have been some recent improvements. Annual data are collected by the NSI, using a census of all establishments. The NSI also obtains current monthly estimates from a quarterly survey of establishments using all public enterprises and a sample of private employers that excludes establishments with less than 5 employees. For 2003, it includes 14,000 private employers out of approximately 113,000 qualifying private enterprises. The main shortcomings of these data include: (i) the under-reporting of private sector wages; (ii) the reporting of only average gross earnings, not wages for time worked and wages by occupation; and (iii) the lack of coverage of the self-employed and employment in small firms. However, the National 
Social Security Institute (NSSI) administrative data are used to estimate wages by occupation and age and the number of self-employed and employment in small firms. The household budget survey could provide an alternative source of data for private sector wages. Regarding employment, the NSI household labor force survey is an alternative source of data, but improvements are needed to make it more consistent with the establishment survey, especially regarding agricultural employment. The survey is conducted four times a year at regular intervals.

9. A Population Census was conducted in early 2001 and is a source for redesigning the household surveys conducted by the NSI, particularly the household budget survey and the labor force survey.

\section{Government finance}

10. In recent years, following the recommendations of a combined STA/FAD mission and within the framework of fiscal reporting requirements for EU accession, the authorities have made great progress on the implementation of accrual accounting for government, budgetary and statistical systems. Consolidated data on central government operations are routinely reported for publication in the GFS Yearbook and in IFS. For the GFS Yearbook 2004, 2003 data for the general government sector and its subsectors were reported on a cash basis. The Ministry of Finance prepares data on the execution of the consolidated government budget on a monthly basis. These data do not conform to GFS standards and while not published in a bulletin format they are posted on the Ministry of Finance's website. The authorities have made progress in presenting data on a disaggregated basis, including expenditure by functional classification. In addition, a full economic classification of expenditure is now available, and the authorities have provided such data on an annual basis back to 1998 .

\section{Money and banking statistics}

11. Statistical methods conform with the key classification and valuation principles of the IMF's Monetary and Financial Statistics Manual, 2000. Consistency in the coverage of the Bulgarian National Bank's (BNB) claims on banks (which included claims on liquidated banks) and the banks' liabilities to the BNB improved in January 2003 after the BNB wrote off most of the claims on the liquidated banks. With respect to its near-term statistical program, the BNB is progressively harmonizing its data collection and compilation methods in line with the European Central Bank's framework for monetary statistics. In particular, a significant number of enhancements in sectoral and instrument detail and classification have progressively been made in the data for 1995 and onward. These were reflected in the revised monetary statistics published in the August 2002, November 2003, and October 2004 issues of IFS. The latter revision in IFS is a consequence of the BNB's statistical work in early 2004, which allowed to recast monetary data to further harmonize with ECB requirements. Among the changes in the national presentation was the creation in February 2004 of a new long-term liabilities category outside the money supply that includes deposits and securities with a maturity over 2 years, deposits redeemable at notice over three months, and capital and reserves. For program purposes, deposits of the newly created public investment 
company, municipalities and social security funds are considered part of the consolidated general government. These deposits are excluded from M3 and included in net lending to the consolidated general government.

\section{Balance of payments}

12. Bulgaria reports monthly balance of payments data on a regular and timely basis, but data on reinvested earnings by foreign-owned companies are subject to large revisions due to incomplete responses on surveys used for preliminary estimates. An IMF technical assistance mission in December 2000 made a number of recommendations to strengthen the balance of payments and external debt compilation systems, which included the development of a closed-type of international transactions reporting system, the development of estimates of "shuttle trade" with countries bordering Bulgaria, strengthening the methodology for travel transactions, and compiling data on trade credit liabilities. The treatment of the license to operate a mobile telephone service has been clarified and agreed with the BNB. As a result the GSM license purchase has been recorded under foreign direct investment (equity capital) in the first quarter of 2001. As there is no repayment obligation, the transaction did not change the country's external debt position. Balance of payments transactions related to the mobile phone license are no longer recorded for the subsequent periods.

13. In 2003, the ROSC mission identified the following problems in the balance of payments statistics: i) residents' foreign currency accounts with resident banks are incorrectly included; ii) merchandise trade data are prone to errors and are not timely; and iii) most data are collected on a cash basis. More recently, large revisions to the data on reinvested earnings for 2003 have revealed that the sample used to obtain the preliminary data for this series is inadequate, in part because of the omission of the largest firms. 
Table 21. Bulgaria: Common Indicators Required for Surveillance

As of February 28, 2006

\begin{tabular}{|c|c|c|c|c|c|c|c|}
\hline & \multirow[t]{2}{*}{ Date of latest observation } & \multirow{2}{*}{$\begin{array}{l}\text { Date } \\
\text { received }\end{array}$} & \multirow{2}{*}{$\begin{array}{c}\text { Frequency } \\
\text { of } \\
\text { data }^{6}\end{array}$} & \multirow{2}{*}{$\begin{array}{c}\text { Frequency } \\
\text { of } \\
\text { reporting }^{6}\end{array}$} & \multirow{2}{*}{$\begin{array}{l}\text { Frequency of } \\
\text { publication }\end{array}$} & \multicolumn{2}{|c|}{ Memo Items: } \\
\hline & & & & & & $\begin{array}{c}\text { Data Quality - } \\
\text { Methodological soundness }\end{array}$ & $\begin{array}{l}\text { Data Quality Accuracy } \\
\text { and reliability }\end{array}$ \\
\hline Exchange Rates & Jan 2006 & $2 / 1 / 2006$ & $\mathrm{D}$ & $\mathrm{D}$ & $\mathrm{D}$ & & \\
\hline $\begin{array}{l}\text { International Reserve Assets and Reserve Liabilities of } \\
\text { the Monetary Authorities } 1\end{array}$ & Nov 2005 & $1 / 13 / 2006$ & M & $\mathrm{W}$ & $\mathrm{D}$ & & \\
\hline Reserve/Base Money & Dec 2005 & $1 / 31 / 2006$ & $\mathrm{~W} / \mathrm{M}$ & M & $\mathrm{D}$ & \multirow[t]{4}{*}{$\mathrm{O}, \mathrm{O}, \mathrm{LO}, \mathrm{LO}$} & \multirow[t]{4}{*}{$\mathrm{O}, \mathrm{O}, \mathrm{O}, \mathrm{O}, \mathrm{O}$} \\
\hline Broad Money & Dec 2005 & $1 / 31 / 2006$ & $\mathrm{~W} / \mathrm{M}$ & M & $\mathrm{W} / \mathrm{M}$ & & \\
\hline Central Bank Balance Sheet & Dec 2005 & $1 / 31 / 2006$ & $\mathrm{~W} / \mathrm{M}$ & $\mathrm{W} / \mathrm{M}$ & W & & \\
\hline Consolidated Balance Sheet of the Banking System & Dec 2005 & $1 / 31 / 2006$ & & & & & \\
\hline Interest Rates ${ }^{2}$ & Dec 2005 & $1 / 31 / 2006$ & $\mathrm{~W}$ & M & $\mathrm{W}$ & & \\
\hline Consumer Price Index & Jan 2006 & $2 / 16 / 2006$ & M & M & M & $\mathrm{O}, \mathrm{LO}, \mathrm{O}, \mathrm{O}$ & LO, LO, O, O, O \\
\hline $\begin{array}{l}\text { Revenue, Expenditure, Balance and Composition of } \\
\text { Financing }{ }^{3} \text { - General Government }{ }^{4}\end{array}$ & 2004 & $2 / 28 / 2005$ & A & A & A & \multirow[t]{2}{*}{ O, LO, O, LO } & \multirow[t]{2}{*}{$\mathrm{LO}, \mathrm{O}, \mathrm{O}, \mathrm{O}, \mathrm{NO}$} \\
\hline $\begin{array}{l}\text { Revenue, Expenditure, Balance and Composition of } \\
\text { Financing } 3 \text { - General Government }\end{array}$ & Dec 2005 & $1 / 31 / 2006$ & M & M & M & & \\
\hline $\begin{array}{l}\text { Stocks of Central Government and Central Government- } \\
\text { Guaranteed Debt }^{5}\end{array}$ & Nov 2005 & $1 / 2006$ & Q & Q & Q & & \\
\hline External Current Account Balance & Nov 2005 & $1 / 13 / 2006$ & M & M & M & \multirow[t]{2}{*}{ LNO, LO, O, LO } & \multirow[t]{2}{*}{ LNO, LNO, LNO, LO, LO } \\
\hline Exports and Imports of Goods and Services & Nov 2005 & $1 / 13 / 2006$ & M & M & M & & \\
\hline GDP/GNP & $\begin{array}{r}2005 \text { Q3 (Quarterly); } \\
2004 \text { (Annual) }\end{array}$ & $12 / 19 / 05$ & $\mathrm{Q} / \mathrm{A}$ & $\mathrm{Q} / \mathrm{A}$ & Q & $\mathrm{O}, \mathrm{LO}, \mathrm{O}, \mathrm{LO}$ & $\mathrm{O}, \mathrm{O}, \mathrm{O}, \mathrm{O}, \mathrm{O}$ \\
\hline Gross External Debt & Nov 2005 & $1 / 27 / 2006$ & M & M & M & & \\
\hline
\end{tabular}

${ }^{1}$ Includes reserve assets pledged or otherwise encumbered as well as net derivative positions.

${ }^{2}$ Both market-based and officially-determined, including discount rates, money market rates, rates on treasury bills, notes and bonds.

${ }^{3}$ Foreign, domestic bank, and domestic nonbank financing.

${ }^{4}$ The general government consists of the central government (budgetary funds, extra budgetary funds, and social security funds) and local governments.

${ }^{5}$ Including currency and maturity composition.

${ }^{6}$ Daily (D); Weekly (W); Monthly (M); Quarterly (Q); Annually (A); Irregular (I); Not Available (NA).

${ }^{7}$ Reflects the assessment provided in the data ROSC published in December 2003, which is based on the findings of the mission that took place during January 15-30, 2003 for the dataset corresponding to

the variable in each row. The assessment indicates whether international standards concerning (respectively) concepts and definitions, scope, classification/sectorization, and basis for recording are fully

observed (O), largely observed (LO), largely not observed (LNO), or not observed (NO).

${ }^{8}$ Same as footnote 7, except referring to international standards concerning (respectively) source data, statistical techniques, assessment and validation of source data, assessment and validation of

intermediate data and statistical outputs, and revision studies.

\section{CInternational Monetary Fund. Not for Redistribution}


Mr. Rodrigo de Rato

Managing Director

International Monetary Fund

Washington, D.C. 20431

U.S.A.

Dear Mr. de Rato:

1. The attached Second Supplementary Memorandum of Economic and Financial Policies (SSMEFP) describes the performance under the economic program that is supported by the Stand-By Arrangement (SBA) approved by the International Monetary Fund on August 6, 2004 and the policies that the government and the Bulgarian National Bank (BNB) intend to pursue in 2006 as part of the 2004-06 economic and financial program outlined in the Memorandum of Economic and Financial Policies attached to the letter of July 21, 2004 and amended by the Supplementary Memorandum of Economic and Financial Policies attached to the letter of April 26, 2005. Notwithstanding the change of government in August 2005 , the core objectives, supported by the policies described in the SSMEFP, remain the maintenance of macroeconomic stability and sustained high rates of economic growth in the run-up to EU membership in 2007. Rising external vulnerability has recently added to this policy challenge.

2. As described in the SSMEFP, macroeconomic stability in 2005 was adversely affected by rising excess demand and supply shocks, with the result that economic growth was somewhat faster while inflation and the external current account deficit were much higher than expected at the time of the first stand-by review. Nonetheless, all quantitative performance criteria for June 30 and September 30, 2005 -- as well as the indicative targets for December 31, 2005 -- have been observed. However, three structural performance criteria for September 30, 2005 were missed, and we request waivers for their nonobservance.

- The previous government selected the winning bidder for two of the three thermal power plants offered for privatization in May 2005 but it canceled the tender for the Bobov Dol power plant due to the unsatisfactory offers received. The new government is prepared to accept the highest bid for this plant and to start negotiations to that effect with the highest bidder provided that a suit brought to challenge the privatization has been successfully resolved. If this approach is unsuccessful, the plant will be re-offered for sale. However, as we cannot guarantee that the court will reach a decision in time for us to decide on the buyer before the end of the arrangement, we request that this structural performance criterion be 
waived. Our efforts to complete the privatization of the two other power plants have recently failed, in part because the competition agency ruled that both plants could not be sold to the same bidder and in part because we could not meet the additional demands of the successful bidder. We will now retender the two plants and intend to select the winning bidders for these plants by June 30, 2006 (a structural performance criterion).

- The delay in forming a new government and the priority given to legislation related to EU accession made it impossible for parliament to approve the procedural code for the National Revenue Agency (NRA) before the end of September. In the event, parliament approved the NRA procedural code in December 2005, allowing the NRA to start operations at the beginning of 2006.

- The Ministry of Finance received all letters with the necessary information to incorporate the lev-denominated expenditure accounts of the judicial system in the budgetary payments system (SEBRA) by the September 30 deadline. However, because of technical requirements the accounts were incorporated into SEBRA only on October 17, 2005.

3. Because of the delay in completing the second review we are requesting that the third and fourth reviews be combined and completed by September 5, 2006.

4. Approval by parliament of legislation to introduce a new company registration system is a prior action for completion of the second review (SSMEFP, Annex I). In addition, new deadlines have been set for a number of missed structural benchmarks, including the conversion of one of them (parliamentary approval of a new VAT law) to a performance criterion because of its importance for the proper functioning of the NRA (ibidem).

5. The SSMEFP proposes quantitative performance criteria for March 31 and June 30, 2006 as well as indicative targets for September 30 and December 31, 2006, as described in its Annexes II - IV. In addition, program implementation is proposed to be monitored by the three structural performance criteria, the three continuous performance criteria and the eleven structural benchmarks listed in Annex I of the SSMEFP.

6. We believe that the policies set forth in the SSMEFP are adequate to attain the objectives of our program, but we will take any further measures that may become appropriate for this purpose. Bulgaria will consult with the Fund on the adoption of these measures, and in advance of any revisions to the policies contained in the SSMEFP, in accordance with the Fund's policies on such consultations. We will provide the Fund with such information as it requests on policy implementation and achievement of program objectives. The forthcoming third review will reconsider the stance of fiscal policy in light of external current account developments (as mentioned in $q 4$ of the SSMEFP) and the credit restraint measures in light of the observed rate of credit expansion (as mentioned in $\llbracket 13$ of the SSMEFP). 
7. We would like to reaffirm our intention not to make the purchases under the SBA that will become available upon observance of its performance criteria and completion of its reviews and to make all outstanding repurchases to the Fund on the expectations schedule. Indeed, as mentioned in $₫ 15$ of the SSMEFP, we have made early repurchases to the Fund in December 2005 and February 2006 as part of our plan to reduce the public external debt.

Sincerely yours,

/s/

$/ \mathrm{s} /$

$/ \mathrm{s} /$

Plamen Oresharski

Rumen Ovcharov

Ivan Iskrov

Minister of Finance

Republic of Bulgaria

Minister of Economy and Energy

Republic of Bulgaria
Governor

Bulgarian National Bank

Attachment: Second Supplementary Memorandum of Economic and Financial Policies 


\section{Second Supplementary Memorandum of Economic and Financial Policies}

\section{Economic Developments in 2005 and Objectives for 2006}

1. Economic growth is expected to have been stronger than expected in 2005 but the external current account deficit and inflation also exceeded expectations. Led by rapidly growing domestic demand, real GDP is now expected to have grown by 5.6 percent in 2005, compared with 5.5 percent under the program. Although private consumption continued to provide the main contribution to growth, private investment was once more its most dynamic component. With higher incomes and credit sustaining the rise in consumption, private saving contracted and the financing requirements of the rising private investment led to a sharp deterioration of the external current account -much of it due to higher-than-expected imports of investment goods -- notwithstanding a tighter fiscal stance. A dip in export growth -- which we believe to be mostly temporary -- in the second half of the year was also a key factor in the current account deterioration. As a result, the external current account reached 14.9 percent of GDP, compared with 7.6 percent at the time of the first review. Notwithstanding an FDI coverage of the deficit of 72.6 percent, external debt rose to 67.4 percent of GDP by year end. As a result of supply shocks, prices have increased faster in the second half of 2005. Reflecting higher gasoline and natural gas prices, food price hikes in the wake of summer floods, and adjustments in the regulated prices of electricity and heating, yearend consumer price inflation reached 6.5 percent year on year, compared with 3.5 percent under the program. However, wage pressures remained moderate as unit labor costs declined by 1 percent year on year in the first nine months of 2005, and the unemployment rate declined from 13.1 percent in January 2005 to 10.7 percent in December 2005, reaching a ten-year low of 10.4 percent in November.

\section{Our main economic objectives for $\mathbf{2 0 0 6}$ are to maintain the momentum of} economic growth while reducing the current account deficit and the rate of inflation. Fiscal tightening, credit restraint, higher food and energy prices, and excise tax increases are expected to reduce the growth of real domestic demand and imports, but export growth should rebound in response to recent investment to expand capacity and the reimposition of textile import restraints by the EU. As a result, we expect real GDP to grow by 5.5 percent. With the attendant recovery in domestic saving and a virtually stable investment ratio, the external current account deficit is projected to decline to 12.9 percent of GDP, compared with a program target of 7 percent. As almost three quarters of this deficit is expected to be covered by foreign direct investment, the net external debt ratio should increase only modestly to 22 percent of GDP. Notwithstanding advance repurchases of external public debt, freely available gross international reserves are expected to cover 4.5 months of prospective imports or nearly 170 percent of short-term external debt. Following an initial increase in response to energy and heating price increases in late 2005 and the January 2006 excise tax increases, consumer price inflation is expected to abate to 5.7 percent by year end. 


\section{The Economic Program Until the End of 2006}

3. Our economic program aims at maintaining a stable policy framework to ensure smooth EU accession on January 1, 2007. The currency board arrangement will remain the cornerstone of our economic policy until euro adoption in 2009-10, as agreed under a strategy prepared in late 2004 by the previous government and the Bulgarian National Bank (BNB) and presented to the EU institutions. The new government reaffirms Bulgaria's commitment to responsible macroeconomic policies and structural reforms to underpin the continued viability of the currency board arrangement. In line with this commitment and against the backdrop of a continued buildup of private excess demand and external debt, our economic program through the end of 2006 relies on fiscal restraint, prudent incomes policies, measures to reduce credit expansion, and structural reforms to strengthen competitiveness.

\section{A. Fiscal Policy}

4. To reverse the deterioration of the external current account, we have considerably tightened the fiscal stance in 2005-06. In 2005, we achieved a general government surplus (defined to treat capital transfers and spending of the public investment projects company -- PIP -- as government expenditure, and adjusted for the net variation of arrears) of 2.3 percent of GDP, compared with a program objective of 1 percent. The tightening went slightly beyond what was called for under the automatic adjustor for tax revenue overperformance in paragraph 4 of the Supplementary Memorandum of Economic and Financial Policies attached to the letter of April 26, 2005 and reflected both revenue overperformance and expenditure restraint in response to the worsened external current account position. In 2006, we will further tighten our fiscal stance by raising the surplus target (defined as above) to 3 percent of GDP (a performance criterion). The budget approved by parliament is balanced at an expenditure level of BGN 17, 412 million $^{14}$. To achieve our fiscal surplus target, we have taken the following actions:

- The 2006 budget law stipulates that 7 percent of discretionary expenditure, which is being withheld until the fourth quarter, will be withheld permanently if the latest available twelve-month external current account deficit exceeds 12 percent of GDP. ${ }^{15}$ To prevent the emergence of arrears when this provision

${ }^{14}$ In the national presentation that corresponds to BGN18,258 million, after adjustment for social security contribution payments (except those to the second pension pillar) for government workers.

${ }^{15}$ For example, in November such a decision would depend on the size of the current account deficit in the twelve months ended in August or September 2006. The current account deficit 
is enforced in late 2006, the government has adopted a decree instructing the recipients of the withheld discretionary funds not to incur any expenditure commitments against them. This measure is expected to improve the fiscal balance by 0.75 percent of $\mathrm{GDP}^{16}$.

- In addition, we will save the expected revenue overperformance relative to the level underlying the budget. This is expected to improve the fiscal balance by 2.25 percent of GDP.

- We will offset any slippage with respect to the targets in the two preceding bullets by additional expenditure cuts (especially for nonroad maintenance and operations) or revenue measures.

If total revenue increases beyond the program's quarterly targets in Annex II, we intend to save 50 percent of any such cumulative quarterly overperformance, and the performance criterion on the fiscal surplus will be raised accordingly. As the weakened external current account is the reason for the fiscal tightening, we are prepared to raise or lower this target at the time of the third review if the current account deviates from its current projection. We will seek to avoid the accumulation of new central government arrears (a performance criterion) and urge the municipalities to eliminate their arrears (which amounted to 0.1 percent of GDP on December 31, 2005).

\section{Buoyant revenue growth allowed an increase in both expenditure and the overall}

surplus in 2005. Revenue rose to 41 percent of GDP (compared with 38.8 percent under the program), as tax bases increased beyond expectations due to higher growth, imports and inflation, with all revenue categories benefiting except pension and unemployment contributions, which remained slightly below original projections as some employers reduced contribution payments in the wake of the summer floods. While most of the tax revenue overperformance has been saved in accordance with the program's adjustor, we had to use most of the balance remaining at the central government level for flood relief (humanitarian assistance and infrastructure repair) and to pay hospital arrears. However, we reduced Christmas bonuses to pensioners to about half the previous year's amount and refrained from making any allocation for such bonuses to government workers. The municipalities and other autonomous bodies also spent most of their extra revenue, much of it to repair flood damage, although perhaps

would be measured on the basis of the balance of payments methodology used by the BNB in January 2006.

${ }^{16}$ In order to make room for spending committed in 2005 but not yet carried out by the PIP, spending is reduced by an additional 0.07 percent of GDP. 
one third of the windfall was saved reflecting calls for restraint by the Ministry of Finance and a lack of projects ready for implementation. As a result, general government expenditure rose to 38.6 percent of GDP (compared with 37.8 percent of GDP under the program), representing a real increase of almost 9 percent year on year. At 2.3 percent of GDP, the overall surplus represented a tightening of the fiscal stance with respect to both the program and the 2004 outcome.

\section{Tax reductions and lower nontax revenue will reduce the revenue ratio to 39.9} percent of GDP in 2006. To lower nonwage labor costs and strengthen competitiveness, we have lowered social security contributions by 6 percentage points to 36.7 percent and reduced the employer's share in these contributions from 70 to 65 percent from January 1, 2006. At the same time, the portion of these payments for eligible contributors to the second pension pillar has been raised from 3 to 4 percent. In addition, we have raised the exemption threshold from the personal income tax from BGN 130 to BGN 180 a month, thus eliminating the lowest tax bracket. To reduce the revenue loss from these measures (and the full-year effect of last year's reduction of the corporate income tax and the introduction of family taxation legislated earlier), we have raised excise taxes by more than envisaged by our commitments to the EU. In addition to the scheduled increases for cigarettes and petroleum products, we have brought forward increases in excises on cigarettes and alcoholic beverages scheduled for 2007 and 2008. Bringing forward these tax increases will also help avoid inflationary pressures during the reference period for the assessment of the Maastricht criteria. As an interim step toward updating property assessments toward current market valuations, we have raised property valuations by some 20-30 percent, which should raise municipal property and property transfer tax revenue by about half of 0.1 percent of GDP in 2006. The net revenue loss from all these measures is estimated at 1.1 percent of GDP in 2006. This loss is more than outweighed by substantial gains from the growth of the tax bases and more modest ones from improved compliance. The start-up of the National Revenue Agency (NRA) on January 1, 2006 and the transfer of excise tax collections to the customs administration on July 1, 2006 have not been factored into the revenue projections. Over time, the NRA is expected to yield substantial revenue gains, but the risk of losses in the start-up phase cannot be excluded. However, early indications are that such losses have been avoided. We will not reduce any other tax rates or bases during 2006 (a performance criterion). Nontax revenue is projected to grow less rapidly than nominal GDP due to the loss of dividends in the wake of recent privatizations and the nonrecurrence of one-time revenue from real estate sales and the auctioning of UMTS licenses in 2005. 
7. After the large increase in 2005, expenditure is programmed to decline to 36.9 percent of GDP. ${ }^{17}$ The budget was prepared to reflect the government's expenditure priorities (viz., EU integration, remaining flood repairs, and social spending including pensions and wages). In particular, in January 2006 pensions were increased by 5 percent on average (with relative increases an inverse function of the size of individual pensions) and teachers' salaries were increased by 4 percent. In July 2006, budget sector wages will be increased by 6 percent on average and teachers' salaries will be increased by the same percentage provided that a reform strategy for the education sector has been prepared by March 31, 2006 and structural reforms have begun to be implemented. Before then, state administration positions will be cut by 4,500 positions through the cancellation of vacancies and the elimination of obsolete structures and overlaps (a benchmark). The net reduction of positions in the state administration will, however, be less as we will hire about 2,000 people in the course of 2006, mainly related to EU accession requirements. As part of ongoing reforms, we are directing our efforts at optimizing the number of people working in education, healthcare, police and the armed forces. To make room for our budgetary priorities, we have kept all other expenditure constant in nominal terms except defense, which is maintained at 2.6 percent of GDP under NATO commitments, and interest, which is expected to decline despite increasing international interest rates because of debt prepayments and regular amortization. As noted in paragraph 4, we intend to realize additional expenditure savings of 0.75 percent of GDP by permanently withholding 7 percent of discretionary spending. All financial operations of the PIP will be concluded by March 31, 2006, and the PIP will be closed by December 31, 2006.

\section{We will strive to keep the finances of the public pension system sound and} strengthen those of the health care system while initiating reform of the education system. We have asked the World Bank for assistance in reforming the health and education sectors.

- The first (public) pension pillar is losing resources because of the reduction of contribution rates and the increase in contributions directed to the second (private) pillar to 4 percent in 2006 and 5 percent in 2007. Nonetheless, with a dependency ratio of now below 1, continued implementation of the 1999 pension reform (notably the gradual increase in the retirement age), and future

${ }^{17}$ At 39.5 percent of GDP in the national presentation, the budget comes close to the 40 percent limit adopted by the new government. For presentational and program purposes, the government's social contributions for its employees (except those for the second pension pillar) of 1.8 percent of GDP and the cuts in discretionary expenditure and transfers to municipalities mentioned in paragraph 4 are excluded to arrive at 36.9 percent of GDP. 
application of the legally enshrined indexation formula, we expect the public pension finances to remain under control. In accordance with a provision of the 2006 budget law, we are preparing a draft law on a Silver Fund to strengthen the financial stability of the first pension pillar in the context of an aging population which will be submitted to parliament by June 30, 2006.

- The public healthcare system suffers from excess capacity in the hospital sector and weak financial management that provides poor value for money and leads to the accumulation of hospital arrears. With World Bank assistance, we will speed up the development of a hospital reform strategy and its implementation. Finding possibilities for additional resources in the sector including privatization of some hospitals as well as a partial sale of buildings and land, higher copayments and increased voluntary insurance are likely to be part of this strategy. In the interim, we have shifted the balance of the resources for the reimbursement of medical services (except for those explicitly reserved for the central government) from the Ministry of Health to the NHIF in the 2006 budget ( 0.5 percent of GDP), thereby reducing the scope for double reimbursements of medical services. We have changed the managements of those of the 15 largest hospitals recently audited which have been found in violation of regulations and have accumulated substantial arrears, and have extended the audits to smaller hospitals. In addition, the National Framework Agreement for 2006 has strengthened control mechanisms and increased the sanctions for violating the provisions relating to the claim for reimbursement of medical services. The National Framework Agreement focuses on the preventive treatment by the general practitioners. The NHIF budget also empowers the parliament to impose the terms of the National Framework Agreement, including reimbursement rates for medical services, should the NHIF and doctors fail to reach agreement by the end of the preceding year. Finally, we have begun virtual reimbursement on the basis of diagnostically related groups (instead of clinical paths) in 9 hospitals of different size and type, with a view to assessing the advantages and disadvantages of this type of financing and taking a decision for its future pilot implementation.

- The recent settlement of a labor dispute with the teachers union has created an opportunity for reforming the education sector, which is overstaffed and suffers from deteriorating output against the backdrop of a secularly declining student population. Under the terms of the agreement with the teachers, we will submit to parliament by March 31, 2006 a strategy for reforming education from preschool to grade 12 that will involve an initial employment cut of at least 5,500 jobs by September 5, 2006 to make room for the cost of reform (two benchmarks). The 6 percent salary increase for teachers on July 1,2006 is conditioned on the timely submission of this strategy. The basic principles of the reform, which should eventually extend to higher education 
and should be financed by efficiency gains, are in line with the goal of optimizing the operation of the education system by way of reviewing the functions and tasks, avoiding overlap and improving the quality of education, strengthen the connectedness of education and the labor market, and increasing the efficiency of the education system. On the basis of this strategy, parliament will adopt in the course of 2006 a ten year reform program laying out a long and medium term vision and quantifiable targets to improve quality, participation, and cost effectiveness. The medium term (3-5 year) program will include policy actions and special measures to achieve these targets as well as medium term projections. The program will emphasize standardized national tests, school autonomy, student based financing, optimization of schools, and accountability for results by central and local government and schools.

\section{We are taking steps to improve revenue administration.}

- The long delayed legal base for unifying the collection of domestic taxes (except excises) and social security contributions was established with the adoption by parliament of the NRA procedural code in December 2005. In mid-2006, the collection of excise taxes will be transferred to the customs administration under a new excise tax law approved by parliament in November 2005. New CIT, PIT and VAT laws are expected to be adopted by parliament, the VAT law as a performance criterion by April 30, 2006 and the CIT and PIT laws as a benchmark by July 31,2006 . In order not to lose momentum and demotivate the staff selected for the NRA, we decided to launch the unified revenue collection on January 1, 2006 although the new software and new headquarters for the agency were not ready. We have adapted the NRA's business practices to cope with these temporary impediments. While launching the NRA has not led to immediate staff savings, we will strive to reduce its staffing once it has become fully operational.

- We will step up efforts to reduce revenue losses from the operation of duty free shops and gas stations. A law on duty free trade specifying limits on individual purchases of goods and fuels, and strengthened controls, will be submitted to parliament by March 31, 2006 with a view to passage by June 30, 2006 (a benchmark). As an immediate step, we have increased surveillance of these outlets to limit abuses of their duty-free status. We are also examining measures to close duty-free outlets within Bulgarian territory or to relocate them to customs areas along the border. The justification of duty free outlets along borders with EU members ceases with EU accession. Closing those along other borders should proceed on a reciprocal basis in close cooperation with the countries concerned. Over time, we believe that duty free outlets should be limited to international airport terminals. 
10. We intend to move toward the full implementation of the current pilot program budgeting system, in collaboration with the international donor community. More specifically, we intend to expand program budgeting, introduced in the 2006 budget for the Ministry of Environment, to an additional 6-7 ministries with the 2007 budget.

11. We remain committed to giving municipalities the autonomy to set their tax rates within certain limits. Conferring this power to the municipalities requires a constitutional amendment, which cannot be initiated by the government and requires a 75 percent parliamentary majority. We will continue to work toward this end, with support from USAID and the European Commission.

\section{B. Income and Labor Market Policies}

12. In the current excess demand situation the public sector's wage and labor market policies are crucial to help maintain competitiveness and enhance labor supply.

- The annual mid-year wage adjustment by 6 percent in the budget sector is expected to signal restraint for private sector wage bargaining. We will again limit the increase of the aggregate wage bill of the 58 largest public enterprises that are monopolies, received government subsidies, made losses, or had arrears in the third quarter of 2005. For 2006, the increase in the aggregate quarterly wage bill of these enterprises over its level in the third quarter of 2005 has been limited to 5 percent. Observance of this limit will be monitored on a cumulative quarterly basis (a performance criterion). Following its 25 percent increase in early 2005, the minimum wage has been raised by 6.7 percent to BGN 160 at the start of 2006 and it will be maintained at that level until the end of 2006 (a performance criterion). A further increase to BGN 170 is planned for 2007.

- Due to the change in government the two measures to improve the functioning of the labor market have slipped beyond their envisaged completion dates. The government has resumed the discussions with the social partners and agreement has been reached to intensify the social dialog through reviving the National Council for Tripartite Cooperation. Within that framework, we expect to reach agreement by March 31, 2006 (i) to find a solution repealing the obligatory character of the portability of seniority bonuses in the case of unemployment, change of employer, or job position (a benchmark) and (ii) to increase work time flexibility by raising the legal limits on maximum working hours, lengthening (perhaps annualizing) calculation periods, and expanding the reasons for work outside regular hours (a benchmark). A decree implementing the former measure is expected to be issued by June 30, 2006 (a benchmark) and a draft law incorporating the second set of measures is expected to be submitted to parliament by June 30, 2006 (a benchmark). In addition, we intend to reach agreement with the social partners on including existing seniority bonuses in 
workers' basic pay, allowing subsequent increases in wages to be negotiated by the social partners at the individual, sectoral or national levels.

\section{Financial Sector and Public Asset and Liability Management}

\section{As a contribution to the reduction in excess domestic demand, the BNB has taken} additional measures to slow the rate of bank credit expansion. Bank credit expansion slowed to 32.3 percent (11 percent of GDP) in 2005. An unexpected increase in late December reflected year-end considerations and was partly unwound in January 2006. Hence, the BNB's efforts to slow credit expansion to 30 percent in 2005 remained essentially on track. In October 2005 the BNB extended the existing credit expansion limits of 6 percent of the adjusted end-March 2005 base per quarter with the intention of slowing bank credit expansion further to 17.5 percent (7.1 percent of GDP) in 2006 while preventing banks from circumventing its credit restraint measures. To this effect, measures including the following have been taken or will be adopted:

- The BNB has extended the quarterly limits on the penalty-free growth of credit beyond March 31, 2006 to the end of 2006.

- The penalty deposit rate for banks exceeding the limit by 1-2 percent was raised from 200 to 300 percent, and to 400 percent for excesses of more than 2 percent.

- To make the credit limits more effective, the excess of local nongovernment nonbank sector bonds issued to banks over and above their stock outstanding on December 31, 2005 will be brought under the credit limits starting from the first quarter of 2006.

- The provisioning requirements for impaired household credits have been raised for loans overdue by 30-60 days from 10 percent to 20 percent and for loans overdue by $60-90$ days from 50 percent to 75 percent and provisions made for such credits may not be released until six months after the credits have begun to be fully serviced again.

- The risk weighting used for calculating the capital adequacy ratio will be increased for mortgage loans by lowering the loan-to-value ratio from 70 percent to 50 percent from April 1, 2006.

- The BNB has issued a recommendation to the banks not to extend credit to households which do not have disposable income of at least BGN100 per household member per month after taxes and all debt service (including that for the requested loan) have been deducted from officially declared income. Where regular supervisory examinations reveal that this recommendation has not been followed, inspectors will reflect this in their reports and suggest appropriate supervisory measures. 
- On the BNB's request, banks have agreed to disclose effective interest rates on their consumer loans. Such disclosure will be extended to all household loans following adoption of the new consumer protection law, expected by June 30, 2006.

With these measures, the BNB's prudential requirements exceed international best practice in many areas. It is the BNB's intention to establish a level playing field for domestic banks after all restrictions to the access of foreign banks to the domestic market have been lifted with EU accession on January 1, 2007. For this reason, the possibility of easing some of the restrictions in light of the evolution of domestic bank credit in relation to the projections will be examined at the time of the third review. If, however, bank credit expands more rapidly than envisaged, the BNB is prepared to take additional measures at the time of the third review.

\section{We are undertaking a number of steps to strengthen supervision of nonbank} financial intermediaries and improve their operations. A new insurance law compliant with EU regulations and facilitating supervision was approved by parliament in December 2005. An amendment to the social security code was approved by parliament in February, 2006. It eliminated the geographical limitation on pension fund investments with respect to EU and European Economic Area member countries and lift the minimum thresholds for investment in government securities. An expansionary effect on the domestic private sector from the lifting of the minimum thresholds is not expected because of the small size and volatility of the domestic capital market. Leasing companies have been requested by the BNB under the foreign exchange law to report on their income statements and balance sheets on a quarterly basis with effect from September 30, 2005. Finally, a law on the consolidated supervision of financial conglomerates has been drafted and is expected to be submitted to parliament soon, with adoption envisaged by September 5, 2006 (a benchmark). This law assigns the supervision of such conglomerates to either the $\mathrm{BNB}$ or the Financial Supervision Commission depending the dominant activity of these conglomerates.

\section{Public asset and liability management will continue to aim at reducing gross} public debt. Fiscal surpluses and privatizations have led to steady inflows into the Fiscal Reserve Account (FRA) in the BNB. We have used these inflows to buy back all of our Brady bonds (the last issue in July 2005), make early repurchases to the Fund in December 2005 and February 2006, and prepay a portion of World Bank loans in January 2006. These prepayments have contributed to lowering the public debt ratio to $32 \frac{1}{4}$ percent of GDP at end-2005 and a projected $281 / 2$ percent at end2006. A guarantee deposit with a foreign bank has additionally reduced our freely usable international reserves by 1 percent of GDP. We have no immediate plans for additional external debt prepayments, but such prepayments remain a policy objective subject to the maintenance of an adequate level of freely usable international reserves. We have again established ceilings on the contracting and guaranteeing of 
external public debt, including two loans for the procurement of military equipment (performance criteria), and trust that these ceilings will ward off pressures for entering into other such contracts during the program period.

\section{Other Structural Reforms}

16. The new government is still in the process of firming up its structural reform agenda. We share the broad thrust of the previous government's reform efforts, directed at improving the business climate, reducing corruption, regulating natural monopoly prices, and restructuring and privatizing public enterprises. The elaboration of detailed plans will take time, but we hope to discuss more fleshed-out plans during the third stand-by review. In the meantime, we intend to complete the following reforms from the previous government's unfinished agenda.

- We have submitted to parliament draft legislation that transfers business registration from the courts to the Registration Agency, an agency under the Ministry of Justice, which will set up and operate the new unified national electronic register efficiently under simplified administrative procedures. Amendments to the draft aimed at eliminating ex-ante judicial review in the registration process. The law specifies that registration will be completed within 10 days in uncontested cases. Efficient operation would require reducing the staff of the current fragmented system from some 400 to no more than 100 , allowing a reduction of registration and information access fees to about one half of the current level. We expect a law preserving the essential features of this draft to be approved by parliament before completion of the second review (a prior action), and plan to make the new registry operational, at least for all new business registrations, by June 30, 2006 at the latest (a performance criterion).

- We will support the State Electricity and Water Regulatory Commission (SEWRC) in its independence in setting the tariffs for electricity, heating, and water and sewerage. Following the phased increase in electricity tariffs for households to cost recovery levels in recent years, the SEWRC raised tariffs for commercial customers by 16 percent in the case of low voltage users in October 2005 to equalize them with household tariffs and by 9 percent for medium voltage users. Following natural gas price increases of 20 percent, the SEWRC raised district heating prices by 16-25 percent depending on the region of users, effective November 1, 2005. With these actions, the SEWRC has eliminated cross subsidies. It also eliminated preferential tariffs for usage up to social thresholds. Following the recent adoption by parliament of the water services law and secondary legislation approved by the council of ministers in late 2005, the SEWRC will initiate a regulatory review of the water sector with a view to setting prices that will attract investors to the sector, which is plagued by heavy water losses and decapitalization. 
- We are aware of the close link between the control of corruption and competitiveness and economic growth and therefore reaffirm our commitment to the previous government's anti-corruption program and policies, as outlined in paragraph 15 of the Supplementary Memorandum of Economic and Financial Policies that is attached to the letter of April 25, 2005. The previous government's action plan for 2004-05 under the 2001 National AntiCorruption Strategy contains 160 measures, 80 percent of which had been implemented by the end of the third quarter of 2005. We expect the implementation rate to have risen to $85-90$ percent by the end of 2005 . In the meantime, we are preparing a new action plan for 2006. As part of the new action plan, a special code of ethics for the highest government officials was adopted by the Council of Ministers in December, 2005 and is already in force. A separate code of ethics for members of parliament is currently under preparation in parliament's new ethics commission. Under the 2006 action plan, we intend to take measures to strengthen the capacity of the public administration to initiate procedures against civil servants under their existing code of ethics. A disciplinary commission under the Supreme Judicial Council is in charge of fighting corruption in the judiciary. We expect to make headway against high-level corruption with the aid of the recently adopted criminal procedures law that will enter into force in early 2006, after appropriate training of the magistrates. Finally, the Ministry of Interior and the Ministry of Finance are undertaking in-depth reviews of property and tax declarations. It is expected that their report to the asset forfeiture commission will lead to recommendations to the courts to take action under the asset forfeiture law adopted in February 2005.

- We are committed to further privatization of state assets and are currently examining how to proceed. After the recent failure of the privatization of the Rousse and Varna electricity generation companies, we will offer these companies for a renewed round of bidding and intend to select the winning bidders by June 30, 2006 (a structural performance criterion). As regards the third company (Bobov Dol), we are prepared to start negotiations with the bidder that has submitted the highest offer provided that the court proceedings will result in a court decision that is favorable for completing this transaction. If these negotiations are not successful, we will resubmit the plant to public tender. The remaining four district heating companies are expected to be privatized by September 30, 2006. With regard to Bulgartabac Holding, we have decided to liquidate the Haskovo plant and to privatize immediately the Plovdiv plant. As to the remainder of the holding, we will decide shortly on how to proceed on the basis of three options recently prepared for the restructuring and/ or privatization of the holding company. Privatization strategies for the airline and the maritime shipping company will be sent to parliament in the first and second quarters of 2006, respectively, with a view to privatizing both companies, along with the remainder of the river shipping 
company, by the end of 2006. We plan to sell our minority stakes in a number of companies after completion of an ongoing review. Finally, we will examine whether some companies currently exempt from privatization as per the Annex to Article 3, paragraph 1 of the privatization law can be removed from that list for future privatization. Our provisional thinking is, however, that the electricity and gas transmission networks and the nuclear power plant should remain under state ownership. In this connection, we have decided to split Bulgargaz and the National Electricity Company each into a transmission operator and a supplier of gas and electricity, respectively.

- Existing capacity of ports and airports represents an increasing constraint on the expansion of economic activity and tourism. We have therefore decided to sell concessions for operating and expanding port and airport terminals to the private sector and will report on steps taken and plans for the remainder of 2006 at the time of the third stand-by review.

\section{E. Statistical issues}

17. We will collaborate with the National Statistical Institute to improve macroeconomic statistics. There is an urgent need for a breakdown of national account data into household and business sectors to facilitate monitoring and addressing the risks arising from external vulnerability. There is also a need for more information on the sectoral breakdown and nature of investment to assess the likely supply response and for comprehensive corporate and household balance sheet data to assess vulnerabilities. Developing these data will take time and may require technical assistance in statistics. 


\section{Bulgaria: Conditionality Under the Stand-By Arrangement in 2006}

\section{Prior Action}

1. Approval by parliament of legislation transferring business registration to the Registration Agency under the Ministry of Justice and establishing a unified national electronic register with limited judicial oversight and simplified administrative procedures.

\section{Quantitative Performance Criteria}

1. Floor on the overall surplus of the general government (Annex II).

2. Ceiling on central government arrears (Annex II).

3. Ceiling on the wage bill of the 58 largest SOEs in financial distress or monopoly situation (Annex III).

4. Ceiling on the contracting or guaranteeing of nonconcessional external public debt (short term, 1-5 years, longer) (Annex IV).

\section{Structural Performance Criteria}

1. Approval by parliament of the new VAT law (April 30, 2006).

2. Start-up of operations of the new business register, at least for all new business registrations (June 30, 2006).

3. Selection of the winning bidders for the Rousse and Varna electricity generation companies (June 30, 2006).

\section{Continuous Performance Criteria}

1. No imposition of new or intensification of existing restrictions on the making of payments and transfers for current international transactions, nor introduction or modification of multiple currency practices, nor conclusion of any bilateral payments arrangements that are inconsistent with Article VIII of the IMF Articles of Agreement, nor imposition or intensification of any import restrictions for balance of payments purposes, nor accumulation of any external payments arrears.

2. No reduction of tax rates and bases (except for those described in $₫ 6$ of the SSMEFP).

3. The monthly minimum wage not to exceed BGN160. 


\section{Bulgaria: Conditionality Under the Stand-By Arrangement in 2006 (Concluded)}

\section{Structural Benchmarks}

1. No new extrabudgetary funds or state-owned enterprises to be created.

2. Agreement with social partners on a solution repealing the obligatory character of the portability of seniority bonuses in the case of unemployment, change of employer, or job position (March 31, 2006).

3. Agreement with social partners to increase work time flexibility by raising the legal limits on maximum working hours, lengthening calculation periods, and expanding the reasons for work outside regular hours (March 31, 2006).

4. Submission to parliament of an education reform strategy envisaging an initial employment cut of at least 5,500 (March 31, 2006).

5. Reduction of central administration employment by 4,500 positions (June 30, 2006).

6. Adoption of a decree repealing the obligatory character of the portability of seniority bonuses in the case of unemployment, change of employer, or job position (June 30, 2006).

7. Submission to parliament of legislation to increase work time flexibility, as agreed with the social partners (June 30, 2006).

8. Approval by parliament of a law on duty free trade specifying limits on individual purchases of goods and fuels and strengthened controls (June 30,2006)

9. Approval by parliament of new CIT and PIT laws (July 31, 2006).

10. Approval by parliament of a law on consolidated supervision of financial conglomerates (September 5, 2006).

11. Implementation of an employment cut of at least 5,500 positions in the education sector (September 5, 2006). 
Performance Criteria on the General Government Balance and Central Government Arrears and Indicative Revenue Targets for the General Government

\begin{tabular}{|l|r|r|r|}
\hline & $\begin{array}{c}\text { Fiscal } \\
\text { Surplus } \\
\text { Floor }\end{array}$ & $\begin{array}{c}\text { Arrears } \\
\text { Ceiling 1/ }\end{array}$ & $\begin{array}{c}\text { Overall } \\
\text { Revenue } \\
\text { Target 2/ }\end{array}$ \\
\hline & \multicolumn{3}{|c|}{ (In millions of leva) } \\
\hline $\begin{array}{l}\text { Cumulative change from January } \\
1,2006\end{array}$ & 256 & 5 & 4,251 \\
\hline March 31, 2006 & 786 & 5 & 9,051 \\
\hline June 30, 2006 & 1,099 & 5 & 13,554 \\
\hline September 30, 2006 2/ & 1,387 & 5 & 18,454 \\
\hline December 31, 2006 2/ & & & \\
\hline
\end{tabular}

1/ Arrears ceiling is on the stock of central government arrears.

2 / Indicative target on general government revenue (including grants).

Quarterly limits in this Annex are cumulative with the exception of central government arrears.

The general government accounts are defined to comprise the consolidated budget (including the republican budget, the budgets of ministries and local governments, and the social security funds NSSI and NHIF) as well as all extrabudgetary funds and accounts at the central and local government levels, the public investment projects (PIP) enterprise, and the environment enterprise. The central government is defined as the general government minus the sum of the local government budgets and the extrabudgetary funds and accounts at the local government level.

For program monitoring purposes, the arrears of the central (general) government are all overdue obligations on the payment for central (general) government expenditure excluding items in dispute. The stock of central government arrears as of December 31, 2005 amounted to BGN 4.8 million.

For program monitoring purposes, the fiscal balance (surplus/deficit) will be defined as the difference between general government revenue (taxes, nontaxes, and grants) and general government expenditure, including net capital transfers (net acquisition of shares and net lending) and adjusted for the net change of the stock of general government arrears. In contrast with the national practice, in the program definition the government's social security contributions for its own workers (except those to the second pension pillar) are excluded from both revenue and expenditure. In 2006, the quarterly fiscal balance targets will be raised by 50 percent of the excess of actual over targeted cumulative general government revenue (including grants). If general government revenue (including grants) exceeds the 
program's target of BGN 18,454 million, 50 percent of any such cumulative quarterly revenue overperformance will be saved and the fiscal surplus floor raised accordingly.

Reporting on the fiscal balance will be cross checked from the financing side as the sum of net credit from the domestic banking system to the general government, general government deposits and accounts abroad, net domestic nonbank credit to the general government, privatization receipts of the central and municipal government budgets, receipts from external loans for project implementation and direct budgetary support minus amortization due, net disbursement/repayment of loans whose final payee is an entity outside the general government consolidation (on lending operations), and the net increase/decrease of general government arrears, including those on the amortization of principal. For calculating the performance against this ceiling, all privatization receipts are treated as financing items. External flows will be converted into leva at the BNB daily exchange rate. Valuation changes in deposits and accounts that are denominated in foreign currencies will be recorded daily and reported by the BNB and the Ministry of Finance at the end of each quarter, and such changes will be netted out.

All data in this Annex will be reported quarterly by the Ministry of Finance (and by the BNB for some of the financing items in the preceding paragraph) within 60 days of the end of each calendar quarter. 
Performance Criteria on the Wage Bill of 58 State-Owned

Enterprises (SOEs)

Wage Bill of 58 SOEs

(In millions of leva)

Cumulative from 1 January 2006

March 31, 2006

89.2

June 30, 2006

September 30, 2006 1/

December 31, 2006 1/

1/ Indicative Limit

The quarterly ceiling on the aggregate wage bill of the 58 state-owned enterprises closely monitored for their large losses or arrears, for receiving subsidies, or for being monopolies, is 5 percent above the level of the aggregate wage bill in the third quarter of 2005 and is accumulated by the same amount for each subsequent quarter. The wage bill is defined to include wages and payroll taxes paid by the employer but does not include additional compensation under Article 12 of the 2005 Incomes Ordinance.

Those enterprises that have been privatized or ceased operations will be excluded from the list for the respective test dates. Those enterprises that register profits in each of the first two quarters of 2006 will also exit the list in the second half of 2006 unless they are monopolies, have arrears, or receive state subsidies. If an enterprise is excluded from the list, the wage bill ceiling for each subsequent quarter will be adjusted down by the amount of that enterprise's wage bill in the third quarter of 2005 plus 5 percent times the number of quarters it has been excluded from the list. The 58 enterprises monitored are in the table below (enterprises numbers 1 to 4 are considered monopolies). 


\section{List of 58 Monitored State-Owned Enterprises}

1 State Railways

2 Railway Infrastructure

3 BulgarGas

4 The National Electricity Company

5 Kozloduy Nuclear Powerstation

6 Varna Power Station

7 Bobov Dol Power Station

8 Bobov Dol Coal Mine

9 Pirin Coal Mine

10 Russe Urban Heating Company

11 Shumen Urban Heating Company

12 Plovdiv Urban Heating Company

13 Sofia Urban Heating Company

14 Varna Urban Heating Company

15 Sliven Urban Heating Company

16 Pernik Urban Heating Company

17 Sofia Urban Transport Company

18 Plovdiv Urban Transport Company

19 Varna Urban Transport Company

20 Sofia Electric Urban Transport Company

21 Pernik Troley Bus Urban Transport Company

22 Pleven Urban Bus Transport

23 Diana Bus Company

24 Passanger Transport

25 Aytos Bus Transport

26 Bus Transport

27 Beltrans

28 Russe Urban Bus Transport

29 Roshen Express
30 Burgas Sea Port

31 Terem Khan Krum

32 Terem Georgi Benkovsky

33 Terem Ovech

34 Terem Letetz

35 Terem Ivaylo

36 Khaskovo BT

37 Gotze Delchev BT

38 Shumen BT

39 Kardjali Bulgartabak

40 Yambol BT

41 Sandansky BT

42 Assenovgrad BT

43 Stroitelstvo and Vazstanovjavane

(Construction and Refurbishing) Public Company

44 Transport Construction and Repair Public Company

45 Public Works

46 Military Supplies Company

47 Spatial and Urban Public Works

48 Copper Well

49 BalkanCar Sredetz

50 BalkanCar Dunav

51 BalkanCar Erma

52 Dupnitza Supply Water and Wastewater Services

53 Supply Water and Wastewater Services

54 Supply Water Engineering

55 Vazov Mechanical Engineering Plants

56 Rudozem GORUBSO

57 Land Geodetic Metrology

58 Rope Ways 
Performance Criteria and Indicative Targets on the Ceilings on Contracting or Guaranteeing of Public Sector External Debt 1/2/

(In millions of euros)

One year and under 3/ Over 1 year $4 / \quad 1-5$ years $4 /$

Cumulative change from

December 31, 2005

March 31, 2006

June 30, 2006

September 30, 2006

December 31, 2006

0

0

$05 /$

$05 /$
293.0

331.4

$372.35 /$

$496.35 /$
0

0

$05 /$

$05 /$

1/ The public sector comprises the central government, the local government, the social security fund and all other extrabudgetary funds and the Bulgarian National Bank.

2/ The term "debt" has the meaning set forth in point No. 9 of the IMF Guidelines on Performance Criteria with Respect to Foreign debt adopted on August 24, 2000 (Executive Board Decision No. 12274-(00/85)). Excluded from this performance criterion are (i) normal import-related financing credits; and (ii) outstanding balances under bilateral payments arrangements. Debt and commitments falling within the ceilings shall be valued in euros at the program exchange rates of $1.21 \mathrm{US} \$ / €$.

3/ The ceilings apply to debt with original maturities of up to and including one year. The actual stock of short-term debt outstanding (according to this definition) as of December 31, 2004 was zero.

4/ The ceilings apply not only to "debt," but also to commitments contracted or guaranteed for which value has not been received.

5/ Indicative limits. 


\section{Statement by the IMF Staff Representative \\ April 3, 2006}

1. This statement provides information on recent revisions to historical data, new data releases, and the outstanding prior action that has become available since the issuance of the staff report on March 16. The new information does not change the thrust of the staff appraisal.

2. Historical data for the current account deficits in $\mathbf{2 0 0 4}$ and $\mathbf{2 0 0 5}$ have been revised down. The change in the balance of payments methodology that led to these revisions was foreshadowed in the staff report ( $\Phi 6$, footnote 4 ) and has been endorsed by the IMF Statistics Department. ${ }^{1}$ The 2004 deficit was lowered from 8.5 percent of GDP to 5.8 percent, and the 2005 deficit was reduced from 14.9 percent of GDP to 11.9 percent (see attached table and text figure). Although the level of the current account deficit in both years is lower than previous estimates, the deterioration between 2004 and 2005 remains broadly unchanged at over 6 percentage points of GDP. The lower deficits and an upward revision of 2004 inward investment have also raised the FDI coverage of the current account deficit (from 73 to 87 percent in 2005).

\section{Data for January 2006 show a further deterioration of the current account} deficit. Based on the new methodologies, in January 2006 the 12-month current account deficit deteriorated by almost one percentage point to 12.8 percent of GDP (text figure). Unusually large oil imports by the refinery and a weak services balance played a key part in this deterioration. At this stage, staff continues to expect the current account balance to improve later in 2006 consistent with the projections in the staff report. Taken together, the revised historical data and the new data for January 2006 do not significantly change the thrust of the analysis contained in the staff report-namely that rising private demand and exogenous shocks have increased external vulnerabilities beyond levels envisaged under the 2005 economic program.

\footnotetext{
${ }^{1}$ The revisions are mainly to the income balance following the introduction of a new methodology for calculating migrant labor's earnings abroad, and to the services balance to account for the living and transportation expenses of these individuals. In addition, a change in the methodology for calculating the transportation cost of trade led to a small improvement in the current account balance. Work to revise the data prior to 2004 is still underway.
} 
Bulgaria: Current Account Deficit in Percent of GDP

(12-month rolling, January 2004-January 2006)

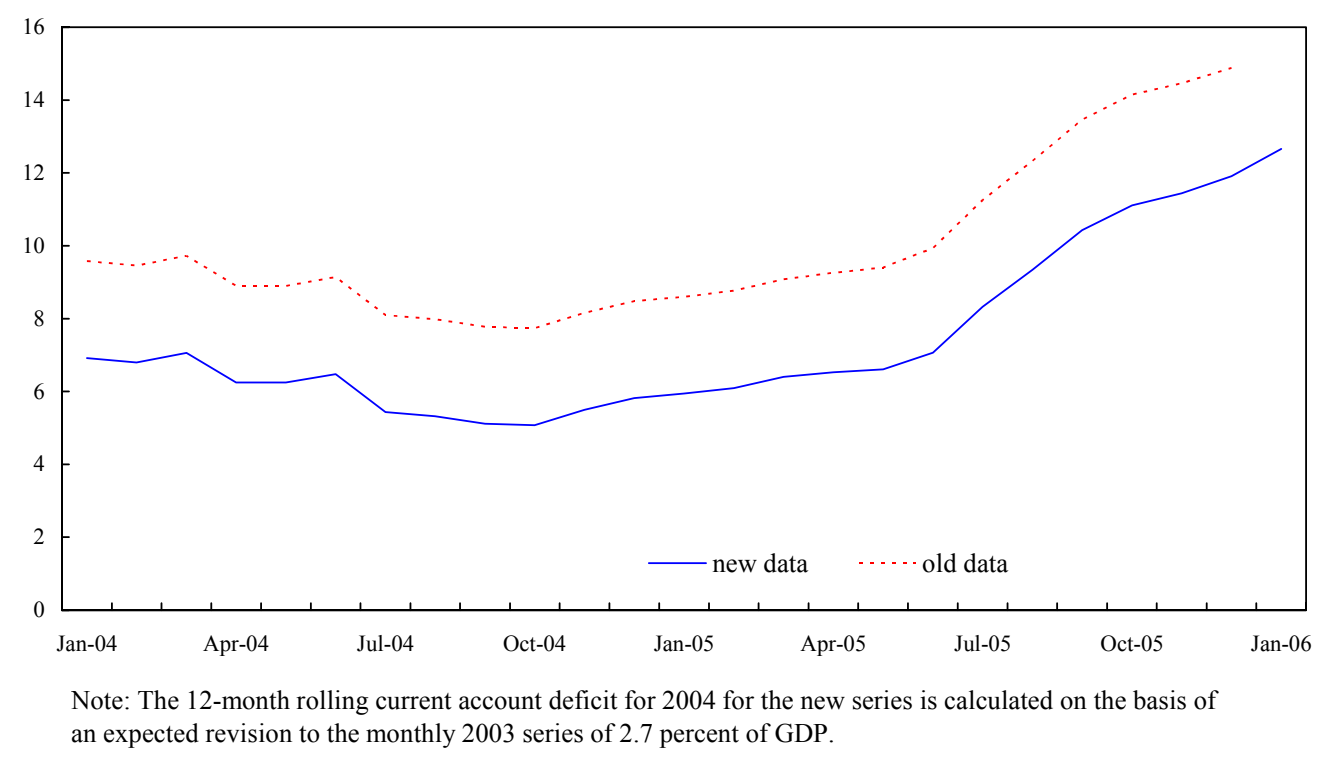

4. Historical data used to compute unit labor costs for manufacturing have also been partially revised, with possible consequences for the assessment of competitiveness. The National Statistical Institute has revised upward employment data for 2004 and 2005, reflecting a larger survey of companies. Other things being equal, the new data reduce staff estimates of productivity in manufacturing, resulting in an appreciation of the estimated unit labor cost based real effective exchange rate (ULC-REER) for that sector. Specifically, in contrast to the average depreciation of 5 percent during January-September 2005 shown in the staff report (Figure 3), the average ULC-REER now shows an appreciation of 1.9 percent for 2005 as a whole. However, expected revisions to output data for manufacturing could raise estimates of productivity, implying a smaller deterioration in the ULC-REER. This issue remains under investigation.

\section{Headline inflation in February 2006 was higher than projected, but core} inflation has eased somewhat. Year-on-year inflation reached 8.8 percent, compared with a staff projection of 8.2 percent, mainly due to a higher-than-projected impact of the January excise tax increases. By contrast, year-on-year core inflation remained steady at 3.5 percent in February 2006, about the same rate as the previous two months.

\section{The remaining prior action has been implemented and faster-than-} anticipated progress has been made with privatization. Parliament approved the business registration law and ancillary amendments in related laws on March 24, thus completing the prior action. The privatization agency agreed to sell the Varna electricity generation company well ahead of the end-June performance criterion. Moreover, discussions on the sale of the Bobov Dol electricity generation company are 
expected to be brought to a successful conclusion soon, following the recent resolution of the court case. 
Table 1. Bulgaria: Balance of Payments, 2004-2006 (In millions of euros)

\begin{tabular}{|c|c|c|c|c|c|}
\hline & \multicolumn{2}{|c|}{2004} & \multicolumn{2}{|c|}{2005} & \multirow{2}{*}{$\frac{20061 /}{\text { Proj. }}$} \\
\hline & Old & $\overline{\mathrm{New}}$ & Old & $\overline{\mathrm{New}}$ & \\
\hline CURRENT ACCOUNT & $-1,648$ & $-1,132$ & $-3,163$ & $-2,531$ & $-2,416$ \\
\hline Trade balance & $-2,729$ & $-2,954$ & $-4,083$ & $-4,369$ & $-4,711$ \\
\hline Exports (f.o.b.) & 7,985 & 7,985 & 9,454 & 9,454 & 12,005 \\
\hline$y$-o-y change (in percent) & 19.7 & 19.7 & 18.4 & 18.4 & 27.0 \\
\hline Imports (f.o.b.) & $-10,714$ & $-10,938$ & $-13,537$ & $-13,823$ & $-16,716$ \\
\hline $\mathrm{y}$-o-y change (in percent) & 20.8 & 23.3 & 26.3 & 26.4 & 20.9 \\
\hline Services, net & 723 & 692 & 532 & 667 & 937 \\
\hline Exports of NFS & 3,362 & 3,262 & 3,587 & 3,444 & 3,967 \\
\hline Imports of NFS & $-2,639$ & $-2,569$ & $-3,054$ & $-2,778$ & $-3,030$ \\
\hline Of which: Exports of travel services & 1,746 & 1,789 & 1,888 & 1,932 & 2,158 \\
\hline Income, net & -531 & 238 & -551 & 247 & 269 \\
\hline Of which: Income to direct investors & -456 & -609 & -522 & -533 & -526 \\
\hline Current transfers, net & 888 & 891 & 938 & 925 & 1,088 \\
\hline CAPITAL AND FINANCIAL ACCOUNT & 3,186 & 2,669 & 3,847 & 3,215 & 3,303 \\
\hline Capital transfers, net & 0 & 0 & -1 & -1 & 0 \\
\hline Foreign direct investment, net 2/ & 1,104 & 1,550 & 2,297 & 2,210 & 2,246 \\
\hline Of which: Privatization receipts 3 / & 243 & 243 & 693 & 693 & 150 \\
\hline Portfolio investment, net & -557 & -564 & -757 & -757 & 46 \\
\hline Other investment, net & 2,220 & 2,047 & 1,274 & 1,199 & 1,011 \\
\hline General government & 102 & 102 & 55 & 55 & 49 \\
\hline Domestic banks & 1,036 & 1,029 & -177 & -189 & -786 \\
\hline Other private sector & 1,081 & 915 & 1,396 & 1,333 & 1,748 \\
\hline Errors and omissions & 419 & -364 & 1,034 & 564 & 0 \\
\hline OVERALL BALANCE & 1,538 & 1,538 & 684 & 684 & 886 \\
\hline FINANCING & $-1,538$ & $-1,538$ & -684 & -684 & -886 \\
\hline Gross international reserves (increase: -) 4/ & $-1,493$ & $-1,493$ & -324 & -324 & -604 \\
\hline Use of Fund credit, net & -44 & -44 & -359 & -359 & -283 \\
\hline Purchases & 62 & 62 & 0 & 0 & 0 \\
\hline Repurchases & -106 & -106 & -359 & -359 & -283 \\
\hline \multicolumn{6}{|l|}{ MEMORANDUM ITEMS } \\
\hline Gross international reserves (stock, e.o.p.) & 6,854 & 6,854 & 7,370 & 7,370 & 7,974 \\
\hline In months of prospective GNFS imports & 5.0 & 5.0 & 4.6 & 4.6 & 4.3 \\
\hline In percent of short-term debt (original maturity) & 276.7 & 276.7 & 200.6 & 200.6 & 179.3 \\
\hline Current account + FDI & -544 & 418 & -866 & -321 & -171 \\
\hline (in percent of GDP) & -2.8 & 2.2 & -4.1 & -1.5 & -0.7 \\
\hline Current account (in percent of GDP) & -8.5 & -5.8 & -14.9 & -11.9 & -10.2 \\
\hline Merchandise trade account (in percent of GDP) & -14.0 & -15.2 & -19.2 & -20.6 & -19.9 \\
\hline Merchandise exports (in percent of GDP) & 41.1 & 41.1 & 44.5 & 44.5 & 50.8 \\
\hline Merchandise imports (in percent of GDP) & -55.1 & -56.3 & -63.7 & -65.0 & -70.7 \\
\hline Export volume (year-on-year change) & 8.8 & 8.8 & 4.1 & 4.1 & 12.9 \\
\hline Import volume (year-on-year change) & 12.8 & 15.2 & 10.9 & 11.0 & 9.1 \\
\hline FDI (net) in percent of current account & 67.0 & 137.0 & 72.6 & 87.3 & 92.9 \\
\hline Gross external debt (stock, e.o.p.) & 12,522 & 12,522 & 14,325 & 14,325 & 15,531 \\
\hline (In percent of GDP) & 64.4 & 64.4 & 67.4 & 67.4 & 65.7 \\
\hline Public & 6,429 & 6,429 & 5,139 & 5,139 & 5,255 \\
\hline Private & 6,093 & 6,093 & 9,186 & 9,186 & 10,277 \\
\hline Short-term debt (in percent of total debt, e.o.p.) & 19.8 & 19.8 & 25.6 & 25.6 & 27.9 \\
\hline Net external debt (in percent of annual GDP) 5/ & 17.4 & 17.4 & 21.5 & 21.5 & 19.2 \\
\hline GDP & 19,433 & 19,433 & 21,254 & 21,254 & 23,632 \\
\hline
\end{tabular}

Sources: Bulgarian authorities, and Fund staff estimates.

1/ New staff projections based on revised BOP data and WEO assumptions of March 10, 2006.

2/ The figures for 2004 and 2005 are influenced by a complex debt financed merger and acquisition transaction of a local mobile telephone

company that led to a sharp increase in its equity value, and a transfer of the realized capital gains out of the country by the original owners. This resulted in a net

FDI outflow of 650 million euros and an increase in gross external debt by 590 million euros in 2004 .

3 / Privatization receipts for the electricity distribution companies are included in 2005. These are included in the receipts for 2004 in the balance of payments presentation of the BNB. The present treatment aligns them with its receipt in the fiscal accounts.

4/ Includes valuation changes.

5/ External debt minus gross foreign assets of the banking system. 
Press Release No. 06/70

FOR IMMEDIATE RELEASE

April 4, 2006
International Monetary Fund

Washington, D.C. 20431 USA

\section{IMF Executive Board Completes Second Review Under Stand-By Arrangement for Bulgaria}

The Executive Board of the International Monetary Fund (IMF) today completed the second review of Bulgaria's economic performance under the Stand-By Arrangement. In completing the review, the Board approved the authorities' request for a waiver for the non-observance of the end-September 2005 structural performance criteria on the selection of winning bids for the sale of three large thermal electricity companies, the adoption by parliament of the National Revenue Agency procedural code and the incorporation into the budgetary payments system of all lev-denominated expenditure accounts of the judicial system. The Board approved the authorities' request to merge the third and fourth reviews under the Stand-By Arrangement and postpone the third review under the arrangement until no later than September 5, 2006.

The 25-month Stand-By Arrangement was approved on August 6, 2004 (see Press Release No. 04/175) for an amount equivalent to SDR 100 million (about US\$144.1 million). The completion of the second review enables the release of SDR 78 million (about US\$112.4 million). The authorities continue to treat the arrangement as precautionary.

Following the Executive Board discussion, Ms. Anne O. Krueger, First Deputy Managing Director and Acting Chair, said:

"The Bulgarian authorities' economic program for 2006 aims at continued strong economic growth, dealing with the large increase in the external imbalance and the increase in inflation that occurred in 2005, and strengthening the balance sheets of the government and the commercial banks. The program relies on measured fiscal tightening, restrained incomes policies, a further reduction of credit growth to slow the expansion of domestic demand, and structural policies to stimulate supply.

"The authorities' 2006 fiscal program aims at an increase in the general government surplus. To achieve this, the authorities are determined to avoid revenue losses in the wake of ongoing reforms of the revenue administration, keep expenditure to the agreed limit by enforcing the planned cuts in discretionary expenditure, and resist pressure for raising spending in other areas. The authorities are committed to tighten the fiscal stance further if the current account does not improve as envisaged under the program. 
"Incomes policies under the program include wage restraint in the government and selected state enterprises and no change of the minimum wage during the remainder of 2006. These measures and recent and prospective reductions of nonwage labor costs are expected to underpin competitiveness.

"Financial deepening will continue. Specifically, the Bulgarian National Bank has extended the limits on banks' credit expansion until the end of 2006 and raised the penalties for banks exceeding them in an effort to limit credit growth. New prudential measures will restrain the growth of household credit and strengthen banks' balance sheets. As the credit limits are encouraging the growth of nonbank financial intermediation, the authorities have introduced reporting requirements for leasing companies and are in the process of strengthening nonbank supervision.

"The program aims to expand supply through a number of structural measures, including judicial reform in the context of EU accession, a new business register, health and education reform, steps to make the labor market more flexible, and the privatization and concessioning of state assets. The firm implementation of these measures is important for ensuring continued high rates of growth and a reduction of the macroeconomic imbalances," Ms. Krueger said. 


\section{Statement by Jeroen Kremers, Executive Director for Bulgaria and Victor Ivanov Yotzov, Advisor to Executive Director \\ April 3, 2006}

Political changes that took place since the last Board meeting, in May last year, did not detract Bulgaria from maintaining macroeconomic stability and sustained economic growth. After signing the European Union (EU) accession treaty in April 2005, the authorities' main objective now is joining the EU in January 2007. Accordingly, the new government's economic program aims at maintaining a stable policy framework to ensure smooth EU accession. Preservation of the currency board arrangement until euro adoption remains the cornerstone.

Against this backdrop, and supported by the precautionary SBA with the Fund, the authorities are committed to pursuing a prudent fiscal policy, and taking measures to moderate credit expansion while conducting prudent income policy and boosting structural reform. In this regard, the authorities would like to express their gratitude for the continued surveillance and assistance from the Fund.

\section{Program conditionality and recent developments}

Performance under the current program has been strong. All quantitative performance criteria and indicative targets for the second review were observed. All structural performance criteria, but one, were also met, with short delays in some cases, due to technical reasons or being outside direct government control. As for the breached structural performance criterion and a few missed structural benchmarks, the non-observance was mainly caused by the time needed to form the new government. Also, the available legislative capacity was stretched given the extensive legislation needed for EU accession. In any case, the authorities are determined to attain the objectives of the program and stand ready to take any further measures to successfully conclude the program. To this end, the authorities request that the third and fourth reviews be combined and completed by September 2006, together with the upcoming Article IV consultation.

Real GDP growth in 2005 was higher than expected under the program and marked the eighth consecutive year with robust economic growth. Private consumption continued to contribute to growth, but private investment was once again its most dynamic component. The GDP growth rate accelerated to 5.8 percent according to the latest estimation, and would have been even higher, but for adverse weather conditions and heavy summer floods causing enormous damage to agriculture.

In the wake of the summer floods, food prices increased faster than anticipated which, along with higher oil prices and subsequent adjustments in the regulated prices of electricity and heating, resulted in a higher than programmed end-year inflation. Core inflation, however, remained low as wage pressures moderated.

Buoyant economic growth, steady capital inflows, and a prudent fiscal policy with significant surpluses over the last two years, resulted in a significant increase of the Fiscal Reserve Account. Accumulated reserves were used to buy back and retire all outstanding Brady bonds, as well as to make early repurchase to the Fund, and prepay a portion of World 
Bank loans. These prepayments have contributed to lowering the public debt ratio, which is expected to fall well below 30 percent of GDP by the end of this year. Further external debt prepayments remain a policy option. Reflecting these positive developments, and in view of the overall optimistic outlook, major international rating agencies have continued to upgrade both foreign and local currency bonds and deposits, which are now enjoying investment grades.

\section{External sector}

Rapid catch-up economic growth is often associated with high investment, exceeding private saving. Like in other countries in the region and worldwide, the same developments can be observed in Bulgaria over the last couple of years. Despite continued increase in public saving, the private sector's saving/investment balance was negative and this translated into a sizable current account deficit.

While the trend of gradual trade balance deterioration has been long established, and considered mostly benign, the trade balance was seriously affected in 2005 by exogenous shocks. Even though merchandise export proceeds increased by 18 percent, they fell somewhat short of expectations as summer floods damaged crops and infrastructure, negatively affecting exports of agricultural raw materials and processed goods. On top of this, the major steel producer is engaged in reconstruction, while the impact of the expiration of the MFA was larger than anticipated. Notwithstanding such recent developments, the authorities and staff share the view that most of the adverse shocks are of rather temporary nature, and the real exchange rate and competitiveness are not an issue. This is well evidenced by declining relative unit labor costs and constantly rising export market shares.

Reflecting strong economic growth and higher oil prices, merchandise imports increased in 2005 by 26 percent. The composition of imports, however, shifted markedly to investment goods, financed predominantly by foreign direct investment, thus suggesting the prospect of economic expansion ahead. Import growth is expected to moderate in the years to come, although it will most likely remain strong in line with robust GDP growth and rising imports of investment goods and raw materials for export processing.

On to the level of the current account deficit, staff has based its analysis on old data according to which it widened to almost 15 percent of GDP in 2005. For some time it has been known that this overstates the size of the deficit. Revised data show a deficit in 2005 of less than 12 percent of GDP - still large but substantially less so. The risk of exaggerating the current account numbers has been flagged on several occasions, including by this Chair in the Board as early as in 2004. From an economic point of view, the numbers as measured under the old methodology were implausible. The next program review will presumably be based on current data and on an in-depth economic interpretation, so as to avoid any impression of being over-excited prima facie about Bulgaria's external accounts. The new data should also be properly reflected in the PIN and in the papers for today's review.

Of course this is not to say that the authorities are insensitive to external vulnerabilities -- to the contrary. They have applied extremely prudent fiscal policies, and taken myriad measures to restrain credit growth. But when assessing the external imbalance, full account must be taken of its context. Bulgaria's catching-up shows the usual combination of a current account deficit financed by massive capital inflows (in the case of Bulgaria, on 
average fully FDI). In itself this is precisely desirable, and policy is carefully attuned to keeping the catching-up process stable and to identifying and controlling its potential vulnerabilities. The Fund can have real value-added by looking not only at the macro-side of this, but also by digging deeper and helping to identify underlying micro-vulnerabilities particularly in the functioning of the financial and corporate sectors. Similarly, analyzing more in-depth the composition of the current account may help to better assess its strengths, weaknesses, and sustainability. Looking at the case of Bulgaria, where no imbalances exist in the public finances themselves, there are limits to the degree to which one can counterbalance external imbalances emanating from private saving/investment patterns by moving the public finances into imbalance as well. With a healthy fiscal surplus in place, the discussion should be, in our view, less about a few tenths of a percent more or less for the surplus and more about these underlying issues.

\section{Fiscal policy}

In an attempt to counterbalance to the degree possible the external deficit, the authorities have considerably tightened the fiscal stance over the last two years. In 2005, the general government surplus was 2.3 percent of GDP, well above the program target of 1 percent, and even higher than what was called for under the automatic adjustor for tax revenue overperformance. To be clear, this is not a primary surplus but an overall surplus. By achieving this result in an election year, Bulgaria has reaffirmed its strong commitment to sound macroeconomic policies, acknowledging the paramount importance of a prudent fiscal stance in the context of the currency board arrangement.

Should the current account deficit not show improvement in the first half of 2006, the authorities consent to further tightening fiscal policy to achieve a surplus of 3 percent of GDP in 2006. Given the already strong fiscal position and demonstrated fiscal responsibility over the years by different governments, this decision was taken with difficulty, as both social partners and the private sector have expressed objections to such restrictive fiscal policy. There is pressure from academic circles, NGOs, trade unions, and various industry associations for lower tax rates.

Under these challenging circumstances, the authorities remain committed to prudent fiscal policy by making every effort to reach their revenue target. Some tax and nontax revenue reductions were introduced in the 2006 budget by lowering social security contributions and raising the exemption threshold for the personal income tax in line with the increased minimum wage. To offset the revenue loss, the government raised excise taxes by more than initially envisaged in their commitment to comply with EU standards, and brought forward increases for tobacco products and alcoholic beverages that were scheduled to take place in the next two years. By taking these measures at this stage, the authorities also hope to lessen inflationary pressures during the reference period in ERM II. After unifying the legal base for collection of domestic taxes and social security contributions, the National Revenue Agency (NRA) started at the beginning of 2006 and is expected to deliver substantial revenue gains in the near future. Early results are quite encouraging.

\section{Credit growth}

After more than three years of rapid credit expansion, 2005 marked an important turnaround as bank credit growth slowed from about 50 percent in 2004 to about 30 percent 
at the end of 2005, and continued to slow in 2006. In view of low nominal interest rates, rising income expectations, and a stable banking system, rapid credit growth was initially interpreted as a welcome and long awaited development. Similar developments were observed in other European countries before joining the EU, while potential risks were successfully contained. But subsequently the authorities recognized that the pace might be on the high side and, when left unchecked, imply risks to financial stability. Accordingly, as of late 2004, the authorities started implementing a strong and coherent package of measures aimed at reducing credit growth. In 2005, the central bank announced amendments to the minimum reserve requirements and established (on a temporary basis, until the end of March 2006) quarterly credit expansion limits of 6 percent, above which banks are subject to an unremunerated deposit requirement. Later in the year, the BNB extended the quarterly limits to the end of 2006, while penalty deposit rates for bank exceeding the limit were raised. In addition, to make the credit limits more effective, bonds issued to banks by the local nongovernmental sector were brought under the credit limits. With these measures in place, the authorities' intention now is to further slow bank credit expansion to about 17-18 percent in 2006. By introducing these and other measures, the BNB's prudential requirements exceed international best practice in many areas.

Notwithstanding results achieved in strengthening prudential regulations and slowing credit growth, important challenges remain as the monetary authorities are fully cognizant of the limited effectiveness of credit restrictions. The open capital account allows the corporate sector to access credit abroad while letting local banks extend credit to households. There are many legal ways to circumvent existing restrictions (albeit at a cost) and some banks are taking advantage of them. In any case, due to the low share of banking assets to GDP, the level of credit to the non-government sector is still lagging substantially behind virtually all the EU countries, including the newcomers, suggesting that credit growth will most likely remain above the EU average for some years to come. 